\title{
Trichoderma-based Products and their Widespread Use in Agriculture
}

\author{
Sheridan L. Woo ${ }^{1,2, *}$, Michelina Ruocco ${ }^{2}$, Francesco Vinale ${ }^{2}$, Marco Nigro ${ }^{1,2}$, Roberta Marra ${ }^{1,2}$, \\ Nadia Lombardi ${ }^{1,2}$, Alberto Pascale ${ }^{1,2}$, Stefania Lanzuise ${ }^{1,2}$, Gelsomina Manganiello ${ }^{1}$ and Matteo \\ Lorito $^{1,2}$ \\ ${ }^{I}$ Dipartimento di Agraria, Università degli Studi di Napoli 'Federico II', Via Università 100, 80055, Portici, Italy \\ ${ }^{2}$ CNR - Istituto per la Protezione delle Piante (IPP-CNR), Via Università 133, 80055 Portici, Italy
}

\begin{abstract}
Governing bodies throughout the world, particularly in Europe, are now implementing legislative mandates with the objective of decreasing dependence on pesticides in agriculture to increase consumer and environmental safety. In order to reduce the risks associated with pesticide applications and reduce dependency on their use, Directives will promote low pesticide-input by implementing integrated pest management (IPM), and provide the means to establish the necessary conditions and measures to employ these practices, as well as to ensure security of commercial products. One approach includes the use of biological control agents and their products as alternatives to synthetic agro-chemicals. Trichoderma spp. are widely studied fungi and are among the most commonly used microbial biological control agents (MBCAs) in agriculture. They are presently marketed as bio-pesticides, biofertilizers, growth enhancers and stimulants of natural resistance. The efficacy of this fungus can be attributed to their ability to protect plants, enhance vegetative growth and contain pathogen populations under numerous agricultural conditions, as well as to act as soil amendments/inoculants for improvement of nutrient ability, decomposition and biodegradation. The living fungal spores (active substance) are incorporated in various formulations, both traditional and innovative, for applications as foliar sprays, pre-planting applications to seed or propagation material, post-pruning treatments, incorporation in the soil during seeding or transplant, watering by irrigation or applied as a root drench or dip. Trichoderma-based preparations are marketed worldwide and used for crop protection of various plant pathogens or increase the plant growth and productivity in diverse cultivated environments such as fields, greenhouses, nurseries; in the production of a variety of horticultural, fruits, trees and ornamental crops. A survey was conducted of Trichoderma-containing products found on the international market to obtain an overall perspective of the: 1) geographical distribution, 2) product composition and identity of Trichoderma species selected, 3) contents combined with Trichoderma in the products - other microbial species or substances in the mix, 4) number of products available globally and geographically, 5) number of products registered or having use specifications, 6) product formulations and applications, 7) manufacturer claims - target use, target pests, product type and effects of applications. The largest distribution of Trichoderma bioproducts is found in Asia, succeeded by Europe, SouthCentral America and North America. The majority of the labels indicated fungicidal properties, but only 38\% of the marketed merchandise are registered. Ten Trichoderma species are specifically indicated, but many labels indicate a generic Trichoderma sp. or spp. mix in the list of ingredients. The most common formulation is a wettable powder, followed by granules. Generally, Trichoderma are applied to the seed or propagation material at the time of planting, then the secondary use is during plant development. On the whole, the target use is for the control of soilborne fungal pathogens such as Rhizoctonia, Pythium and Sclerotinia, and a few foliar pathogens such as Botrytis and Alternaria; whereas the minor use indication is for plant growth promotion. The use of Trichoderma-based biological products will have an important role in agricultural production of the future, in light of changing worldwide perspectives by consumers and governing bodies.
\end{abstract}

Keywords: Biological control, induced systemic resistance, integrated pest management, pesticides, plant growth promotion.

\section{INTRODUCTION}

The use of biological pesticides as an alternative to synthetic pesticides in agricultural production is rapidly increasing due to public concerns about human health, safety of agri-food products consumed and impact to the environment.

*Address correspondence to this author at the CNR - Istituto per la Protezione delle Piante (IPP-CNR), Via Università 133, 80055 Portici, Italy; Tel: +39 081 2539010; Fax: +39 081 2539339; E-mail: woo@unina.it
Conventional crop protection has been predominantly based on the use of chemical pesticides to control plant diseases and pests, a practice that can produce negative effects to the end user and the agro-ecosystem, including inhibition of pollinators, useful predators/parasitoid and beneficial microbial communities. In Europe alone, the consumption of synthetic agro-chemicals is estimated to be about $250 \mathrm{k}$ tonnes, of which about $180 \mathrm{k}$ tons per year are fungicides [1]. Governing bodies in many countries, particularly in Europe, are now implementing mandates that regulate procedures for 
pre-market assessment of safety, with the objective of decreasing dependence on pesticides in order to increase security for consumers and the natural resources.

European Directive 2009/128/EC established a framework "to achieve a sustainable use of pesticides" by reducing the risks and impacts on human health and the environment by promoting integrated pest management (IPM), including the use of biological control agents and their products as alternatives to chemicals. To this scope, the Directive summons the European Member States to promote low pesticide-input IPM practices, including establishment of necessary conditions and measures for implementation, in order to reduce the risks associated with pesticide applications, as well as lower dependency on their use.

EU legislation Directive 91/414 regulates the marketing and use of plant protection products (PPPs), whereas Regulation EC No. 396/2005 checks the setting, monitoring and control of pesticide residues in products of plant and animal origin (that may occur from their prior use in plant protection). Directive 91/414 aims to harmonize the registration of products throughout the EU based on use of a two-tiered system: first, rules and procedures are defined for approval of the active substances (active ingredients) at the EU-level; second, at the level of each individual Member State, the specific authorization of the particular PPP is released. This Directive states that an active substance must first be included in a "positive" EU list (Annex I), then the substance can be used in plant protection products and its application can be authorized by the Member States.

PPPs are generically defined "pesticides" and comprise insecticides, acaricides, herbicides, fungicides, plant growth regulators, rodenticides, biocides and veterinary medicines that affect crop pests and/or production (http: //ec.europa.eu/food/plant/plant_protection_products/index_e n.htm). Pesticides protect crops in pre- and post-harvest by eliminating, inhibiting or controlling pests; may have an effect on plant development, inhibit or kill competitive plants, or aid in the conservation of final products. Most importantly, a pesticide can be commercialized and used in the EU only if it has been scientifically proven that its use does not harm human health, has no undesirable effects on the environment and it is effective against the claimed target pests. Biopesticides are crop protection products that are derived from natural sources including naturally occurring chemicals, pheromones, bacteria, fungi and insect predators [2].

Annex I ('Positive List') is the list of "active substances authorized for use in crop protection products" in the EU and the products containing these substances can subsequently be registered by the relevant, individual Member State. Annex IIB is specific to microorganisms and lists the requirements for the active substance. Annex IIIB lists the requirements for the microbial pesticide product. The process for deciding whether an active substance can be included in Annex I to Directive 91/414 involves a peer review by all Member States, the European Food Safety Authority (EFSA) and the European Commission. It should be noted that for microorganisms, registration is specific to the strain/isolate, and the process for review does not differ substantially from that used to evaluate chemical pesticides. Active substances approved by Regulation (EC) No 1107/2009 are constantly inserted in the EU Pesticides database, Directorate General for Health and Consumers and can be consulted at http: //ec.europa.eu/sanco_pesticides/public/index.cfm?event=acti vesubstance.detail [3].

Microbial Biological Control Agents (MBCA) currently used in agriculture can be classified in two types based on the mechanisms of action used to directly kill or inhibit the causal agents of plant disease and interact with the plant. The group defined as the "generalists", includes species of Bacillus, Pseudomonas, Streptomyces, Trichoderma, Clonostachys, yeasts, etc., that are capable of controlling a large spectrum of taxonomically diverse pathogen hosts by using a variety of mechanisms of action. The group of the "specialists" includes biocontrol species of Agrobacterium, Ampelomyces, Coniothyrium, non-pathogenic Fusaria, atoxigenic Aspergillus, etc. that can counteract only one or few targeted pathogens. The mechanisms of biological control include direct parasitism or mycoparasitism [4-8] from physical penetration, secretion of numerous lytic enzymes [4, 9-14], antibiosis [4, 15-19], competition for nutrients or ecological niches $[13,15,16,20]$. The classification becomes complicated when consideration is made to the indirect positive effects that a MBCA can have on the plant. These include reduced susceptibility to pathogen attack in the instance of induce systemic acquired resistance (ISR) activated molecular effectors/elicitors (enzymes, proteins, secondary metabolites) [21-24], as well as improved resistance to abiotic stresses (drought, salinity, nutrients etc.) $[18,25,26]$ produced by interactions with rhizobacteria or some fungal antagonists such as Trichoderma spp [27]. In reality, many successful microbial BCA use a combination of different modes of action to produce the appreciated beneficial effects on the plant [28, 29].

According to the Pesticide Action Network (PAN) Pesticide Database (http: //www.pesticideinfo.org/) [30], a pesticide is grouped according to: Use Type (i.e. fungicide) and Chemical Class of the active substance/ingredient, whereby a microorganism is categorized as a "Microbial". A MBCA can be classified as Chemical Use Type of "Fungicide" or "Plant Growth Regulator". The registration includes the identification of the specific microbial antagonist/s (generalists or specialists), and the target plant pathogens that can be effectively controlled following criteria similar to those used to evaluate chemical pesticides, considering the direct biochemical mode of action of the PPP on the target pathogen. The involvement of indirect biological control mechanisms, such as ISR, may complicate the registration process since these intrinsic effects are not formally in the criteria used to assess a chemical pesticide. Therefore, a registered biofungicide will have fungicidal properties that are evaluated, but it may also have other beneficial assets such as ISR or plant growth promotion that have not been evaluated, although these characteristics may be indicated on the product label. The difficulty in meeting the criteria of the registration processes means that many potential microbial crop protection products do not pass through the pipeline even though they are considered to produce positive effects in the field. 
Trichoderma spp. have been widely studied, are among the microorganisms most commonly used as biological control agents and are presently marketed as active ingredients of bio-pesticides, biofertilizers, growth enhancers and stimulants of natural resistance. This is due to their ability to protect plants, enhance vegetative growth and contain pathogen populations under numerous agricultural conditions, as well as to act as soil amendments/inoculants for improvement of nutrient ability, decomposition and biodegradation [31-41] The commercial success of products containing these fungal BCAs can also be attributed to the large volume of viable propagules that can be produced rapidly and readily on numerous substrates at a low cost in diverse industrial fermentation systems [42-44]. The living microorganisms can be incorporated into various formulations as pure spores or conidia suspensions, in liquid culture filtrates, and can be integrated with various inert components and stored for months without losing efficacy ([41, 45], Lorito et al., unpublished data). The formulations are applied as a foliar spray, pre-planting application to seed or propagation material, post-pruning treatment, incorporation in the soil during seeding or transplant, watered by irrigation or applied as a root dip or drench. The products are used in the greenhouse, nursery, field, orchards as well as in hydroponics. To date, Trichoderma-based preparations are commercialized worldwide and used for crop protection from various plant pathogens or to increase the plant growth and productivity in a variety of fields, greenhouses, nurseries, horticultural, fruits, trees and ornamental crops [18, 41, 46-50].

The "classical mechanism" of biological control for which Trichoderma was known for was its direct antagonism of phytopathogenic fungi by competition, antibiosis and direct attack with hydrolytic enzymes [39, 51-57]. In particular, some isolates of Trichoderma are well known biocontrol generalists, having the capacity to function against a broad spectrum of fungal pathogens including Botrytis cinerea, Rhizoctonia solani, Sclerotinia sclerotiorum, Sclerotium spp., Pythium ultimum, Phytophthora spp., Armillaria spp., Fusarium oxysporum, Verticillium spp. and Gauemannomyces graminis [10, 46, 49, 50, 58-62]. The species most commonly used in biocontrol include $T$. harzianum, T. atroviride, T. asperellum, T. polysporum, $T$. viride, as well as a few species that belong to the related genus of Gliocladium [63]. The antagonistic potential serves as the basis for effective biological control applications of different Trichoderma strains as biofungicides against soil, foliar and vascular pathogens, as an alternative to chemical pesticides for treatment against a wide spectrum of plant pathogens, as well as to increase resistance to abiotic stresses $[18,64,65]$.

It has been presumed that the effects of Trichoderma to the plant were limited to the control of disease causing phytopathogens. Its persistence in the soil, in particular on the rhizosphere, eventually associated as endophytic, would guarantee long-term advantages. However, more and more evidence has been accumulated that demonstrates that these benefits and effects from Trichoderma applications are much more extensive. Trichoderma is capable of systemically activating plant defence mechanisms including priming, that anticipate pathogen attack [5, 57, 64, 66-69]. The reaction of the plant to the BCA is similar to the ISR elicited by rhizobacteria [70-76]. In fact, the ISR mechanism activated by Trichoderma is now considered to play a very significant role in crop protection as compared to the direct antagonism of the plant pathogens. The phenomenon has been widely observed in a diversity of monocotyledonous and dicotyledonous crops, including graminaceae, solanaceae and cucurbitaceae that have been attacked by pathogens including a variety of fungi ( $R$. solani, $B$. cinerea, Colletotrichum spp., Magnaporthe grisea, Phytophthora spp., Alternaria spp. etc.), bacteria (Xanthomonas spp., Pseudomonas syringae, etc.) as well as viruses (cucumber mosaic virus), although the ISR effect seems to be strongly dependent on the strain of the antagonist and species/cultivar of the plant [21].

Another positive effect to the plant from Trichoderma applications has been the improvement of plant growth, development, and yield. In particular this result has been noted in terms of root growth promotion, although significant increases have also been observed in aboveground vegetative growth such as stem length and thickness, leaf area, chlorophyll content and yield (size and/or number of flowers and/or fruits) [5, 13, 21, 27, 77]. Numerous hypothesis have been proposed to explain this observation including the improvement of chemical solubilisation, sequester, availability (i.e. siderophores production) $[65,78$, 79] and nutrient uptake by the plant [80], as well as the involvement of growth phytohormones from both plant and fungal origin [28, 81]. Not only do these processes improve plant growth, but they also stimulate plant respiration, thus enhancing photosynthesis or photosynthetic efficiency [64], as well as increasing the ability of the plant to withstand abiotic stresses such as drought, salinity, high temperature.

Much more recently, it has been demonstrated that the beneficial effects to the plant can be attributed to the capacity of many Trichoderma spp. to produce specific compounds, derived from secondary metabolism [82] that are antimicrobial, thus contribute to phytopathogen control, and/or positively affect the plant in aspects of growth promotion, increased yield and other desirable characters i.e. augmented anti-oxidant properties [78, 83]. It has also been demonstrated that Trichoderma during its interaction with plants can also play a crucial role in stimulating the production of plant volatiles that influence plant-insect interaction [84]. Major advantages to using Trichoderma derived bioactive compounds i.e. enzymes and other proteins, or secondary metabolites are: i) the removal of constraints associated with development, application and conservation of products containing living microbes; ii) the efficacy in the field is maintained and more precisely dependent on the dose of the active substance used; iii) some applications are more effective, such as foliar spray for the control of aerial pathogens; iv) the direct effect on the plant may be improved and be more reproducible ; v) a reduced sensibility to changing environmental conditions; and vi) the possibility of developing highly active synergistic mixtures containing both the bioactive substances and the living MBCA [57, 85]. 
Furthermore, strains of Trichoderma may also be aggressive biodegraders of compost and act as competitors of fungal pathogens in their saprophytic phases, especially when nutrients are a limiting factor. They are also recognized for their potential in bio- and phytobioremediation of toxic compounds by degrading pollutants particularly in the soil environment [86-88]. The versatility of Trichoderma spp. extends to their adaptability to different ecological surroundings or agricultural situations, as well as to their compatibility with numerous commonly used crop protection products and other biocontrol agents, but also to synergism with many chemical pesticides and other natural compounds, thus permitting a reduction in the pesticide doses normally used in the field [89-91]. All of these characteristics enlarge the scope of potential applications of Trichoderma based products in the agricultural market not only as a biofungicide against phytopathogens, but also as a general bio-inoculant that stimulates plant resistance to biotic and/or abiotic stresses, enhances plant growth and yield, plus improves the agro-ecosystem. Moreover, the prospective use of Trichoderma-based bio-compounds is not limited only to agriculture, but can also be extended to applications in other areas of the earth and life sciences such as environmental ecology [92], medicine [93] or dentistry $[94,95]$ where detoxification and anti-microbial activity may be required.

A general survey on internet indicates that the number of Trichoderma-containing products found on the international market has been growing exponentially in the past 5 years with more than 250 available products (Table 1, Appendix I). A large distribution of Trichoderma biological formulations can be found in all geographical regions worldwide: Africa (6 countries), Asia (8 countries), Europe (14 countries belonging to the European Union, 3 countries associated), North America (2 countries), Pacific (2 countries) and South-Central America (14 countries). The numbers indicated are not absolute because counts are based on the presence of a Trichoderma-based product in each different zone, but the same product may be available in more than one zone. By far, the country with the greatest distribution of Trichoderma biological goods is India, which comprises about $90 \%$ of the Asian market, although only one species appears to be registered for use as a microbial fungicide. Another geographical zone that is developing rapidly in terms of executive use of commercial products based on Trichoderma for plant diseases is South and Central America, in particular, with the greatest distribution possibility found in Brazil.

Based on the PAN Pesticide Database [30] that surveyed 219 countries worldwide across four continents, only 32 countries (or Unions) had pesticide registration data available from diverse national pesticide evaluation agencies. As of 2010, there were 21 different Trichoderma spp. isolates and their corresponding commercialized crop protection products registered internationally, as well as two Gliocladium spp. and their products (Table 2a). All products are classified as microbial fungicides. No Trichoderma spp. appear to be registered as plant growth regulators. Although eight species of Trichoderma have been certified: $T$. asperellum, atroviride, gamsii, hamatum, harzianum, polysporum, virens and viride, not all are yet available on the commercial market as "finished" fungicide products. The countries where Trichoderma has been registered for use include: countries of the European Union (Belgium, Cyprus, France, Italy, the Netherlands, Spain, Sweden, Slovenia and the United Kingdom according to [2], Turkey, two in North America (USA, Canada), Africa (South Africa, Morocco), two in Asia (India, Vietnam) and two in Oceania (Australia, New Zealand). The species of Gliocladium comprised $G$. catenulatum, and $G$. virens, and are registered in the countries of USA, Canada, and the European Union (Belgium, Denmark, Estonia, Finland, Sweden and the United Kingdom). By 2013, 12 of these antagonistic fungi have been further approved for inclusion in Annex I as authorized active substances (EU Pesticides Database, http: //ec.europa.eu/food/plant/pesticides/pestici-

des_database/index_en.htm). The number of products indicated in Table $\mathbf{2 a}$ refers to those that are registered somewhere in the world, but not necessarily in all indicated zones. It should also be noted that in many cases the available biological products (Appendix I) are noted as being approved for use in organic farming, however, this is not by any means equivalent to, or to be confused with products that have obtained full registration and approval, which signifies that the formulation has passed through the stringent evaluation process applied by given official agencies, normally government, and assessed as safe for use.

The proof that there is extensive interest in the production and commercialization of Trichoderma and Gliocladium products can be found in publications that have reviewed the international market of biological products since 2010 [96], from which the data in Table 2a was based EU Commission Pesticide Database 13/11/2012 (http: //ec.europa.eu/sanco_pesticides/public/index). In general, about 38 Trichoderma (comprised of single species and combination mixtures) and one Gliocladium commercial products have been indicated as being registered or in the process of being registered, in diverse countries by the European Commission and by other agencies throughout the world, plus four products have received special registration or temporary approval only for use in field experiments. All of these products have been incorporated in Table $\mathbf{2} \mathbf{b}$, have putative registered products, but lack official data that supports the sources of information or authorization [96, 97]. Continuing with the trend noted so far in the use of the different Trichoderma spp., approximately 50\% of these latest products contain $T$. harzianum.

The greater part of the Trichoderma commercialized products are comprised, according to the label, of a single species $(67 \%)$, whereas the remainder include combinations of known and/or unidentified species, isolates, or a mix of Trichoderma with other beneficial microbes such as mycorrhize (mainly Glomus), bacteria (Bacillus subtilis, Pseudomonas fluorescens etc.) or other biological compounds (Table 3). Once again, the numbers indicated are not absolute because counts are based on the individual species, but the same species can also be found in mixtures. The species of Trichoderma indicated on the labels, as being present in the commercial product include: T. asperellum, $T$. atroviride, T. gamsii, T. hamatum, T. harzianum, T. koningii, 
Table 1. Distribution of Trichoderma-containing crop protection products on the worldwide market. The number of countries and the approximate number of products commercially marketed in the region, including those that are registered (anywhere in the world) are indicated. Label description (product claims) for single characteristics: FUNGicide (FUNG), plant growth STIMulator-enhancer (STIM), FERTilizer or improved NUTRient uptake (FERT/NUTR), DEComposer (DEC), Induced Systemic Resistance (ISR), OTHER - NEMatocide, INSecticide; and combined characteristics. Product formulations: Wettable Powder (WP), Granules (Gran), Liquid (Liq), Solid substrate (Solid), Pellets (Pell), Other formulations: Concentrated Suspension (SC), Emulsion (Emuls), Dry flowable (Flow), Not Indicated (Not Indic). Note: the numbers do not necessarily sum to the number of products indicated since some are available in more than one formulation, or the type useformulation is not indicated.

\begin{tabular}{|c|c|c|c|c|c|c|c|c|c|c|c|c|c|c|c|c|c|c|}
\hline \multirow[t]{2}{*}{ Region } & \multirow[t]{2}{*}{ Countries } & \multirow{2}{*}{$\begin{array}{c}\text { Number } \\
\text { Comm. } \\
\text { Products }\end{array}$} & \multirow{2}{*}{$\begin{array}{l}\text { Number } \\
\text { Products } \\
\text { Register. }\end{array}$} & \multicolumn{9}{|c|}{ Label Description (Single Characteristics and Combinations) } & \multicolumn{6}{|c|}{ Product Formulation } \\
\hline & & & & $\begin{array}{l}\text { FUNG } \\
\text { (F) }\end{array}$ & $\begin{array}{l}\text { STIM } \\
\text { (ST) }\end{array}$ & $\mid \begin{array}{c}\text { FERT/NUT } \\
\mathrm{R} \\
\text { (FERT) }\end{array}$ & ISR & OTHER & $\mathrm{F}+\mathrm{ST}$ & $\begin{array}{r}\mathrm{F}+\mathrm{ST} \\
+\mathrm{FERT} \\
+\mathrm{ISR}\end{array}$ & $\begin{array}{c}\mathrm{F}+\mathrm{ST}+ \\
\text { FERT }\end{array}$ & $\begin{array}{c}\text { Other } \\
\text { Combos }\end{array}$ & WP & Gran & Liq & Solid & Pell & Other \\
\hline Africa & \begin{tabular}{|c}
5 \\
(South Africa, \\
Kenya, \\
Zambia, \\
Morocco, \\
Tunisia)
\end{tabular} & 9 & 9 & 7 & 1 & & & & 1 & & & & 4 & & & & & $\begin{array}{c}\text { SC-1 (Conc. } \\
\text { Susp.) }\end{array}$ \\
\hline Asia & \begin{tabular}{|c}
8 \\
(China, India \\
$(91 \%)$, \\
Indonesia, \\
Japan, Korea, \\
Russia, \\
Vietnam, \\
Philippines)
\end{tabular} & 100 & 8 & 79 & 2 & 2 & & $\begin{array}{c}\mathrm{F}+\mathrm{NEM}=2 ; \\
\mathrm{F}+\mathrm{INS}=1\end{array}$ & 7 & 1 & $\begin{array}{c}2 ; \\
+\mathrm{DEC}=2\end{array}$ & 2 & 51 & 0 & 12 & $\begin{array}{c}6, \\
\text { Rice } 1\end{array}$ & 0 & $\begin{array}{c}\text { Emuls-1; } \\
\text { Not Indic-38 }\end{array}$ \\
\hline Europe & \begin{tabular}{|c|}
17 \\
(BE, CZ, DK, \\
EE, ES, FI, FR, \\
HU, IE, IT, \\
NL, SE, SI, \\
UK) Moldavia, \\
Ukraine, Israel
\end{tabular} & 57 & 21 & 24 & 2 & & & & 14 & 3 & 2 & 3 & $\begin{array}{c}27 \\
\text { (Bees 1) }\end{array}$ & 13 & 5 & $\begin{array}{c}4 \\
\text { (Peat 1, } \\
\text { Coco 2) }\end{array}$ & 1 & Powder-2 \\
\hline North America & $\begin{array}{l}2 \text { (USA, } \\
\text { Canada) }\end{array}$ & 29 & 19 & 16 & 4 & & & & & 3 & 3 & 3 & $\begin{array}{c}19 \\
\text { (Bees 1) }\end{array}$ & 15 & 5 & 3 & 1 & Flow-1 \\
\hline Pacific & $\begin{array}{c}2 \text { (Australia, } \\
\text { New Zealand) }\end{array}$ & 22 & 10 & 8 & 1 & $\begin{array}{c}4 ; \\
+\mathrm{DEC}=2\end{array}$ & & & $\begin{array}{c}2 ; \\
+\mathrm{ISR}=3\end{array}$ & 2 & & & 13 & 3 & & $\begin{array}{c}1 \\
\text { Dowels }\end{array}$ & 1 & Flakes-2 \\
\hline $\begin{array}{c}\text { South-Central } \\
\text { America }\end{array}$ & $\begin{array}{c}14 \\
\text { (Argentina, } \\
\text { Bolivia, Brazil, } \\
\text { Chile, } \\
\text { Colombia, } \\
\text { Costa Rica, } \\
\text { Cuba, Equador, } \\
\text { Honduras, } \\
\text { Mexico, } \\
\text { Panama, Peru, } \\
\text { Uraguay, } \\
\text { Venezuela) }\end{array}$ & 40 & 22 & 32 & & & 1 & $\mathrm{NEM}=1$ & $\begin{array}{c}1 ; \\
+\mathrm{ISR}=1 ; \\
+\mathrm{ISR}+\mathrm{NE} \\
\mathrm{M} \\
=1\end{array}$ & & 1 & 2 & 24 & 3 & 6 & $\begin{array}{c}3 \\
\text { (Rice 1) }\end{array}$ & 1 & $\begin{array}{c}\text { Emuls-1; } \\
\text { Not Indic-7 }\end{array}$ \\
\hline
\end{tabular}


Table 1. contd...

\begin{tabular}{|c|c|c|c|c|c|c|c|c|c|c|c|c|c|c|c|c|c|c|}
\hline Region & Countries & $\begin{array}{c}\text { Number } \\
\text { Comm. }\end{array}$ & $\begin{array}{l}\text { Number } \\
\text { Products }\end{array}$ & \multicolumn{9}{|c|}{ Label Description (Single Characteristics and Combinations) } & \multicolumn{6}{|c|}{ Product Formulation } \\
\hline \multirow{3}{*}{$\begin{array}{l}\text { Multiple } \\
\text { Regions }\end{array}$} & ca. 17 & 16 & 15 & 11 & & & & & 1 & 2 & 2 & & 13 & 3 & & & 1 & \\
\hline & TOTAL & 273 & 104 & 177 & 9 & 8 & 1 & 5 & 31 & 11 & 12 & 2 & 151 & 37 & 28 & 17 & 5 & 13 \\
\hline & $\begin{array}{c}\text { PERCENTAG } \\
\text { E }\end{array}$ & & 38.1 & 64.8 & 3.3 & 2.9 & 0.4 & & 11.4 & 4.0 & 4.4 & & 55.3 & 13.6 & 10.3 & 6.2 & 1.8 & \\
\hline
\end{tabular}

Table 2a. Trichoderma and Gliocladium spp. officially registered as microbial fungicide, crop protection products, in different countries throughout the world as indicated by the Pesticide Action Network, PAN Pesticide Database (Kegley, S.E., Hill, B.R., Orme S., Choi A.H., Pesticide Action Network, North America (San Francisco, CA, USA, 2010), http://www.pesticideinfo.org; EU Pesticides Database of Active Substances, Regulation (EC) No 1107/2009 (http://ec.europa.eu/sanco_pesticides/public/index.cfm?event=activesubstance.detail); BPDB - Bio-Pesticides Database, the University of Hertfordshire (2011) http://sitem.herts.ac.uk/aeru/bpdb/index.htm

\begin{tabular}{|c|c|c|c|}
\hline $\begin{array}{l}\text { Chemical Name - } \\
\text { Trichoderma/Gliocladium spp. }\end{array}$ & $\begin{array}{c}\text { Species Strain; Synonyms; Related } \\
\text { Chemicals }^{1}\end{array}$ & $\begin{array}{l}\text { Commercial USA Product Name } \\
\text { (Manufacturer/Distributor) }\end{array}$ & Country where Registered for Use ${ }^{2}$ \\
\hline $\begin{array}{l}\text { Trichoderma polysporum ATCC } \\
\text { 20475, Trichoderma harzianum } \\
\text { ATCC } 20476 \text { and/or Scytalidium } \\
\text { spp. ATCC } 16675\end{array}$ & $\begin{array}{c}\text { (parent strain } T \text {. harzianum Rifai strain } \\
\text { T-39) }\end{array}$ & No commercial products & Australia, New Zealand, South Africa, Vietnam \\
\hline T. asperellum & T. asperellum strain $\mathrm{T} 34$ (parent strain) & $\begin{array}{c}\text { T34 Biocontrol (Biocontrol Technologies } \\
\text { S.L., Fargro Ltd.) }\end{array}$ & $\begin{array}{l}\text { European Union (Annex I, approved 01/06/2013- } \\
\qquad 31 / 05 / 2023 \text {; UK) }\end{array}$ \\
\hline T. asperellum & $\begin{array}{l}\text { T. asperellum strain ICC } 012 \text { (parent } \\
\text { strain); formerly T. harzianum }\end{array}$ & Remedier WP & $\begin{array}{l}\text { European Union (Annex I, approved 01/05/2009- } \\
\text { 30/04/2019; ES, FR, IT, SI), USA regist; } \\
\text { available Mor, Slov, Turk }\end{array}$ \\
\hline T. asperellum & $\begin{array}{l}\text { T. asperellum strain TV1 (parent } \\
\text { strain); formerly T. viride strain TV1 }\end{array}$ & VIRISAN (Isagro USA) & $\begin{array}{l}\text { European Union (Annex I, approved 01/05/2009- } \\
\text { 30/04/2019; ES, FR, IT, SI) }\end{array}$ \\
\hline T. asperellum & $\begin{array}{c}\text { T. asperellum strain } \mathrm{T} 25, T \text {. asperellum } \\
\text { strain } \mathrm{T} 11 \text {, formerly } T \text {. viride strain } \\
\text { T25 }\end{array}$ & TUSAL (Isagro USA) & $\begin{array}{l}\text { European Union (Annex I, approved 01/05/2009- } \\
\text { 30/04/2019; ES, FR, IT, SI) }\end{array}$ \\
\hline T. atroviride & T. atroviride LC52 & $\begin{array}{c}\text { Trichopel, Trichodry, Trichospray, Vinevax } \\
\text { Biodowel/Pruning, Sentinel*, Tenet* } \\
\text { (Agrimm Technologies Ltd.) }\end{array}$ & New Zealand \\
\hline T. atroviride & T. atroviride $\mathrm{I}-1237$ & Esquive WP (Agrauxine) & $\begin{array}{c}\text { Europe Union (Annex I, approved 01/06/2013- } \\
\text { 31/05/2023; FR), Australia, New Zealand, South } \\
\text { Africa, Vietnam }\end{array}$ \\
\hline T. atroviride & $\begin{array}{l}\text { T. atroviride IMI } 206040 \\
\text { (formerly T. harzianum IMI 206040) }\end{array}$ & $\begin{array}{l}\text { BINAB TF WP in combination with T. } \\
\text { polysporum IMI 206039, Binab T Vector* } \\
\text { (BINAB Bio-Innovation AB); }\end{array}$ & $\begin{array}{l}\text { European Union (Annex I, approved 01/05/2009- } \\
\qquad 30 / 04 / 2019 \text {; IT, SE) }\end{array}$ \\
\hline T. atroviride & $\begin{array}{l}\text { T. atroviride } \mathrm{T}-11 \text { (formerly } \\
\text { T. harzianum } \mathrm{T}-11 \text { ) }\end{array}$ & $\begin{array}{l}\text { No commercial products, strain of } \\
\text { Newbiotechnic S.A. }\end{array}$ & $\begin{array}{l}\text { European Union (Annex I, approved 01/05/2009- } \\
\qquad 30 / 04 / 2019 \text {; IT, SE) }\end{array}$ \\
\hline T. gamsii & $\begin{array}{l}\text { T. gamsii ICC080; formerly } T \text {. viride } \\
\text { strain ICC080 }\end{array}$ & Remedier WP (Isagro USA) & $\begin{array}{l}\text { USA, European Union (Annex I, approved } \\
\text { 01/05/2009-30/04/2019; ES, SI) }\end{array}$ \\
\hline T. hamatum & T. hamatum & No commercial products & New Zealand \\
\hline
\end{tabular}


Table 2a. contd..

\begin{tabular}{|c|c|c|c|}
\hline $\begin{array}{c}\text { Chemical Name - } \\
\text { Trichoderma /Gliocladium spp. }\end{array}$ & $\begin{array}{l}\text { Species Strain; Synonyms; Related } \\
\text { Chemicals }^{1}\end{array}$ & $\begin{array}{l}\text { Commercial USA Product Name } \\
\text { (Manufacturer/Distributor) }\end{array}$ & Country where Registered for Use ${ }^{2}$ \\
\hline T. harzianum & T. harzianum DB 103 & T-Gro (Dagutat Biolab) & USA, South Africa \\
\hline T. harzianum & T. harzianum, ATCC 20476 & $\begin{array}{l}\text { Binab T wettable powder biorational } \\
\text { fungicide (Binab Bio-innovation eftr ab) }\end{array}$ & USA (cancelled) \\
\hline T. harzianum & $\begin{array}{c}\text { T. harzianum Rifai Strain T-22 (ATCC } \\
\text { \# 20847), T. harzianum Rifai strain } \\
\text { KRL-AG2 }\end{array}$ & $\begin{array}{l}\text { Rootshield WP biological fungicide, T-22 } \\
\text { technical, T-22 wp biological fungicide } \\
\text { (Bio-trek nursery drench, Garden solutions } \\
\text { biofungicide for soilborne diseases, Root } \\
\text { guardian biofungicide for soilborne } \\
\text { diseases, Bio-trek hb) (Bioworks inc, } \\
\text { Wilbur Ellis Co., Gardens alive!inc), T-22g } \\
\text { biological plant protectant granules (T-22g } \\
\text { biological plant protectant granules) - } \\
\text { (Bioworks inc) }\end{array}$ & $\begin{array}{l}\text { USA; Australia, Canada, European Union (Annex } \\
\text { I, approved 01/05/2009-30/04/2019; BE, ES, FR, } \\
\text { NL, SE), New Zealand, South Africa }\end{array}$ \\
\hline T. harzianum & $\begin{array}{l}\text { T. harzianum Rifai strain T-22 } \\
\text { (T. harzianum Item 908) }\end{array}$ & $\begin{array}{c}\text { TRIANUM-P and TRIANUM-G (Koppert } \\
\text { B.V.) }\end{array}$ & $\begin{array}{l}\text { European Union (Annex I, approved 01/05/2009- } \\
\text { 30/04/2019; BE, ES, FR, NL, SE), New Zealand }\end{array}$ \\
\hline T. harzianum Rifai & $\begin{array}{l}\text { T. harzianum Rifai strain T-39, } \\
67892313 \text { (CAS); Parent strain }\end{array}$ & $\begin{array}{l}\text { Trichodex (Cancelled USA; Makhteshim } \\
\text { chemical works Ltd) }\end{array}$ & Australia, New Zealand, South Africa, Vietnam \\
\hline T. polysporum & T. polysporum IMI 206039 & $\begin{array}{l}\text { BINAB TF WP in combination with } \\
\text { T. atroviride IMI } 206040 \text { (BINAB Bio- } \\
\text { Innovation AB) }\end{array}$ & $\begin{array}{l}\text { European Union (Annex I, approved 01/05/2009- } \\
\qquad 30 / 04 / 2019 ; \text { SE) }\end{array}$ \\
\hline T. polysporum & $\begin{array}{l}\text { T. polysporum Rifai ATTC } 20475 \\
\text { (T-75) }\end{array}$ & $\begin{array}{l}\text { Binab t wettable powder biorational } \\
\text { fungicide in combination with T. viride } \\
\text { ATCC } 20476 \text { (USA Active), Binab } \\
\text { T Vector*, Binab t pellets biorational } \\
\text { fungicide - cancelled USA - (Binab Bio- } \\
\text { innovation eftr ab) }\end{array}$ & USA, New Zealand, United Kingdom \\
\hline T. viride & $\begin{array}{c}\text { T. viride sensu Bisby , T. viride ATCC } \\
20476 \text { (EPA 119201, CAS 67892-34-6, } \\
\text { T. viridae }\end{array}$ & $\begin{array}{l}\text { Binab T Wettable Powder Biorational } \\
\text { Fungicide in combination with T. } \\
\text { polysporum ATTC } 20475 \text { (Binab Bio- } \\
\text { innovation eftr ab) }\end{array}$ & USA, Cyprus, India \\
\hline T. viride & $\begin{array}{c}\text { T. viride, } T \text {. viride sensu Bisby with } \\
\text { T. polysporum Rifai }\end{array}$ & No commercial products & New Zealand \\
\hline Gliocladium catenulatum & $\begin{array}{l}\text { G. catenulatum strain J1446 (parent } \\
\text { strain) }\end{array}$ & $\begin{array}{l}\text { Primastop biofungicide, Prestop Mix } \\
\text { (Verdera oy) }\end{array}$ & $\begin{array}{c}\text { USA, Canada, European Union (Annex I, } \\
\text { approved 01/04/2005-31/07/2017; BE, DK, EE, } \\
\text { FI, FR, IE,SE,UK) }\end{array}$ \\
\hline Gliocladium virens & G. virens GL-21 (related) & SoilGard 12G (Certis USA, LLC) & USA \\
\hline Gliocladium spp. & Gliocladium spp. & GlioMix* (Verdera oy) & USA, European Union (FI, DE) \\
\hline
\end{tabular}

"Probable registration (source not confirmed) - registration was noted in 2010 on the same species/isolate, by the same company, in other products

${ }^{1}$ Many compounds are chemically similar to each other; however, typically only one of a group has been evaluated for its toxicological properties and this compound is assigned as the "parent." Chemicals that are chemically similar ("related" chemicals) will have similar toxicological effects and/or similar chemical reactivity. All chemicals in a group are related to the parent in one or more ways. Where no toxicity information was available for any member of a group, parent status was assigned to the least derivatized member of the group, for example, in the case of Trichoderma, unless indicated, the parent strain is T. harzianum strain T- 39 .

${ }^{2}$ Sources of PAN registration data for countries having microbial chemical products containing Trichoderma

Australia the Australian Pesticides and Veterinary Medicines Authority APVMA (http://www.apvma.gov.au) (Record of Approved Active Constituents for Chemical Products, National Registration Authority for Agricultural and Veterinary Chemicals (NRA), December 18, 2009, http://www.apvma.gov.au/actives/subpage_actives.shtml. PAN last checked the currency of this data set on January 31,2010).

Canada (the Pest Management Regulatory Agencies (PMRA; www.hc-sc.gc.ca) Registered Pesticides, Pest Management Regulatory Agency (PMRA), 2009, http://pr-rp.pmraarla.gc.ca/portal/page?_pageid=34,6928,34_6956\&_dad=portal\&_schema=PORTAL\&letter=A. PAN last checked the currency of this data set on January 31, 2010. 
Table 2a. contd...

European Union European Food Safety Authority (EFSA;http://www.efsa.europa.eu) (Status of active substances under EU review , European Commission Services, November 10, 2008, http://ec.europa.eu/food/plant/protection/evaluation/index_en.htm. PAN last checked the currency of this data set on December 4, 2008), EU Pesticides Database of Active Substances, Regulation (EC) No 1107/2009 (http://ec.europa.eu/sanco_pesticides/public/index.cfm?event=activesubstance.detail).

New Zealand (Agricultural Compounds and Veterinary Medicines (ACVM) Database on Currently Registered Pesticides, Food and Safety Authority, February 3, 2010, http://www.nzfsa.govt.nz/acvm/registers-lists/. PAN last checked the currency of this data set on January 31, 2010),

South Africa (Agricultural remedies, National Department of Agriculture, December 2007, http://www.nda.agric.za/act36/main.htm. PAN last checked the currency of this data set on January 31,2010$)$,

United Kingdom (Annex I, Health and Safety Executive, 2005, http://www.pesticides.gov.uk/publications.asp?id=44. PAN last checked the currency of this data set on February 3, 2010).

USA Environmental Protection Agency (EPA; http://www2.epa.gov) - Pesticide Action Network North America (PANNA) compiled List of US Registered Active Ingredients from Pesticide Product Information System, and California Registered active ingredients, California Department of Pesticide Regulation. A chemical is listed as 'Registered' because there are U.S. registered products that contain this chemical or it is specifically registered for use in California.

Vietnam (List of Pesticides Permitted, Restricted and Banned to Use in Vietnam Ministry of Agriculture and Rural Development, March 28, 2007, http://www.spsvietnam.gov.vn/EnglishSPS/Pages/List\%20of\%20Pesticides.aspx. PAN last checked the currency of this data set on January 31, 2010)

Table 2b. Crop protection products containing Trichoderma spp. or Gliocladium spp. indicated as being registered more recently than the information summarized in Table 2a (ca. 2010), in different countries worldwide. Data has not been verified by authorized sources of official registration agencies ${ }^{1}$.

\begin{tabular}{|c|c|c|c|}
\hline $\begin{array}{c}\text { Chemical Name -Trichoderma } \\
\text { /Gliocladium spp. }\end{array}$ & $\begin{array}{l}\text { Species Strain; Synonyms; } \\
\text { Related Chemicals }\end{array}$ & Commercial Product Name (Manufacturer/Distributor) & Country Indicated for Registration \\
\hline \multirow[t]{4}{*}{ T. asperellum } & T. asperellum & Ecohope, Ecohope-Dry (Kumiai Chemical Industry Co. Ltd.) & Japan \\
\hline & T. asperellum & Quality WG (Laboratório de Biocontrole Farroupilha Ltda.) & Brazil \\
\hline & T. asperellum & $\begin{array}{c}\text { Trichodermax EC (TURFAL - Industria e comércio de produtos } \\
\text { biológicos e agronômicos Ltda.) }\end{array}$ & Brazil \\
\hline & T. asperellum & Trichotech (Dudutech K Ltd) & Kenya \\
\hline \multirow[t]{14}{*}{ T. harzianum } & T. harzianum & Antagon WP (Bio Ecológico Ltda.) & Colombia \\
\hline & T. harzianum & $\begin{array}{c}\text { Trichobiol WP (Control Biológico Integrado ; Mora Jaramillo } \\
\text { Arturo Orlando - Biocontrol) }\end{array}$ & Colombia \\
\hline & T. harzianum & Unite WP (Agrimm Technologies Limited) & Australia, New Zealand \\
\hline & T. harzianum DSM 14944 & Agroguard WG, Foliguard (Live Systems Technology S.A) & Colombia \\
\hline & T. harzianum isolate DB 104 & Romulus (DAGUTAT BIOLAB) & South Africa \\
\hline & T. harzianum strain 21 & Rootgard (Juanco SPS Ltd.) & Kenya \\
\hline & T. harzianum strain kd & Eco-T (Plant Health Products (Pty)Ltd.) & $\begin{array}{c}\text { South Africa, Kenya and Zambia; in } \\
\text { process FR, UK, Morocco, Tunisia and } \\
\text { India }\end{array}$ \\
\hline & T. harzianum strain SF & Bio-Tricho (Agro-Organics) & South Africa \\
\hline & $\begin{array}{c}\text { T. harzianum strains ESALQ- } \\
\text { 1306, ESALQ-1303 }\end{array}$ & Trichodermil (Itaforte BioProdutos) & Brazil \\
\hline & T. harzianum & Supresivit (Fytovita, Ltd.) & Czech Republic \\
\hline & T. harzianum IIHR-Th-2 & Ecosom-TH (Agri Life) & India \\
\hline & T. harzianum strain B77 & Eco-77 (Plant Health Products) & South Africa; Kenya, Zambia \\
\hline & $\begin{array}{l}\text { T. harzianum T-22 (ATCC } \\
\text { 20847) }\end{array}$ & Tricho D WP (Orius Biotecnologia) & $\begin{array}{l}\text { Colombia, Equador, Panama, Peru, } \\
\text { Chile }\end{array}$ \\
\hline & $\begin{array}{l}\text { T. harzianum, Glomus } \\
\text { intraradices and Pseudomonas }\end{array}$ & Micover Gold e Plus (Agrifutur) & European Union \\
\hline T. harzianum, T. koningii & T. harzianum, T. koningii & Promot WP (Biofa AG, Bio-farming systems) & R in Germany; Kenya (temp. 2010) \\
\hline
\end{tabular}


Table 2b. contd...

\begin{tabular}{|c|c|c|c|}
\hline $\begin{array}{c}\text { Chemical Name -Trichoderma } \\
\text { /Gliocladium spp. }\end{array}$ & $\begin{array}{l}\text { Species Strain; Synonyms; } \\
\text { Related Chemicals }\end{array}$ & Commercial Product Name (Manufacturer/Distributor) & $\begin{array}{c}\text { Country Indicated for } \\
\text { Registration }\end{array}$ \\
\hline $\begin{array}{l}\text { T. harzianum, T. koningii, } \\
\text { T. viride }\end{array}$ & $\begin{array}{l}\text { T. harzianum, T. koningii, } \\
\text { T. viride }\end{array}$ & Fitotripen WP (Safer Agrobiologicos) & Colombia \\
\hline T. harzianum, T. virens & T. harzianum and T. virens & Bio Traz, BioFit (Biomycota) & Chile \\
\hline T. virens & T. virens $\mathrm{G}-41$ & $\begin{array}{l}\text { G-41 Technical, BW240 G, BW240 WP Biological Fungicide } \\
\text { (Bioworks Inc) }\end{array}$ & USA \\
\hline $\begin{array}{l}\text { T. virens, T. harzianum, } \\
\text { T. parceanamosum }\end{array}$ & $\begin{array}{l}\text { T. virens, T. harzianum, } \\
\text { T. parceanamosum }\end{array}$ & Trichonativa (Bio-Insumos Nativa Ltda) & Chile \\
\hline \multirow[t]{3}{*}{ T. viride } & T. viride & Biocure F (T. Stanes and Company Limited) & EU; available India \\
\hline & T. viride & Bio-Shield, Bioveer (Ambika Biotech) & India \\
\hline & T. viride 16, T. lignorum & Mycofungicyd ,Trichodermin (Bizar-agro LTD) & Ukraine \\
\hline \multirow[t]{5}{*}{ Trichoderma spp. } & Trichoderma spp. & Excalibur Gold, Excalibur Green (ABM) & USA \\
\hline & Trichoderma spp. & $\begin{array}{l}\text { Registration of Trichoderma containing products indicated, but not } \\
\text { specified }\end{array}$ & China \\
\hline & Trichoderma spp. & Tricho Plus (Biological Control Products (Pty)Ltd) & South Africa \\
\hline & Trichoderma spp. & Trichozam (Hardware \& Lumber Limited (Agro Grace Division) & Honduras, Colombia \\
\hline & Trichoderma $\mathrm{Td} 82$ and $\mathrm{Td} 84$ & Solstice (Metcalf Biologicals) & Australia \\
\hline Gliocladium spp. & Gliocladium spp. & GlioMix (Verdera Oy ( Formerly Kemira Agro Oy)) & USA; Finland, Germany \\
\hline Temporary Registration & $\begin{array}{c}\text { T. viride, T. harzianum, } \\
\text { T. koningii and Trichoderma spp. }\end{array}$ & ICB Nutrisolo SC e WP (ICB BIOAGRITEC Ltd) & Brazil \\
\hline Temporary Registration & Trichoderma spp. (6 strains) & Agrotrich e Agrotrich Plus (Agrosafra Sementes) & Brazil \\
\hline Use permit only & T. harzianum A-34 & Trichosav-34 (Institute for Research in Plant Protection (INISAV)) & Cuba \\
\hline Use permit only & T. harzianum A-55 & Trichosav-55 (Institute for Research in Plant Protection (INISAV)) & Cuba \\
\hline
\end{tabular}

'Reference Sources:

Kabaluk, J. Todd, Antonet M. Svircev, Mark. S. Goettel, and Stephanie G. Woo (ed.). 2010. The Use and Regulation of Microbial Pesticides in Representative Jurisdictions Worldwide. IOBC Global. 99pp. http://www.iobc-global.org/publications_iobc_use_and_regulation_of_microbial_pesticides.html

Bettiol W., M. A. B. Morandi, Z. V. Pinto, T. J. de Paula Jr., É. B. Corrêa, A. B. Moura, C. M. M. Lucon, J. de Cássia do Bomfim Costa, J. L. Bezerra. 2012. Produtos comerciais à base de agentes de biocontrole de doenças de plantas/ Wagner Bettiol... [et al.]. - Jaguariúna, SP : Embrapa Meio Ambiente, 2012; 155 p. — (Documentos / Embrapa Meio Ambiente; 88), 1a edição eletrônica. http://ainfo.cnptia.embrapa.br/digital/bitstream/item/66628/1/Doc-88-1.pdf

Table 3. Worldwide distribution of crop protection products that contain Trichoderma or Gliocladium (as a single species, in multiple species combinations, or with other microbial beneficials and/or compounds). For each geographical region, there are indications of the: number of countries that market these products, number of products on the commercial market (Number Comm. Products); Trichoderma species present (as indicated on the label) - T. asperellum (asp), T. atroviride (atrv), T. gamsii (gam), T. hamatum (ham), T. harzianum (harz), T. koningii (kon), T. lignorum (lign), T. parceanamosum (parc), T. polysporum (polys), T. virens (virns), T. viride (virid), T. species mix (Spp. Mix); Gliocladium - G. virens (Gvirn), species mix (Gli spp.); combined with mycorrhize spp. (Myco), bacteria (Bact.) or other substances (Other) in the formulation.

\begin{tabular}{|c|c|c|c|c|c|c|c|c|c|c|c|c|c|c|c|c|c|c|c|c|c|}
\hline \multirow[t]{2}{*}{ Region } & \multirow[t]{2}{*}{ Countries } & \multirow[t]{2}{*}{$\mid \begin{array}{c}\text { Number } \\
\text { Comm. } \\
\text { Products }\end{array}$} & \multicolumn{2}{|c|}{$\begin{array}{c}\text { Products } \\
\text { Containing } \\
\text { Trichoderma }\end{array}$} & \multicolumn{12}{|c|}{ Trichoderma Species Used in Product: } & \multicolumn{2}{|c|}{ Gliocladium } & \multicolumn{3}{|c|}{ In Combination with } \\
\hline & & & \begin{tabular}{|c} 
Singl \\
e sp.
\end{tabular} & $\begin{array}{c}\text { Mix } \\
\text { spp., } \\
\text { cmpds }\end{array}$ & asp & atrv & gam & ham & harz & kon & lign & parc & polys & virns & virid & $\begin{array}{l}\text { Spp. } \\
\text { Mix }\end{array}$ & Gvirn & $\begin{array}{r}\text { Gli } \\
\text { spp. }\end{array}$ & Мyco & Bact & Other \\
\hline Africa & $\begin{array}{c}5 \text { (South } \\
\text { Africa, Kenya, } \\
\text { Zambia, } \\
\text { Morocco, } \\
\text { Tunsisia) }\end{array}$ & 9 & 7 & 2 & 1 & & & & 7 & 1 & & & & & & 8 & & & & & \\
\hline
\end{tabular}


Table 3. contd...

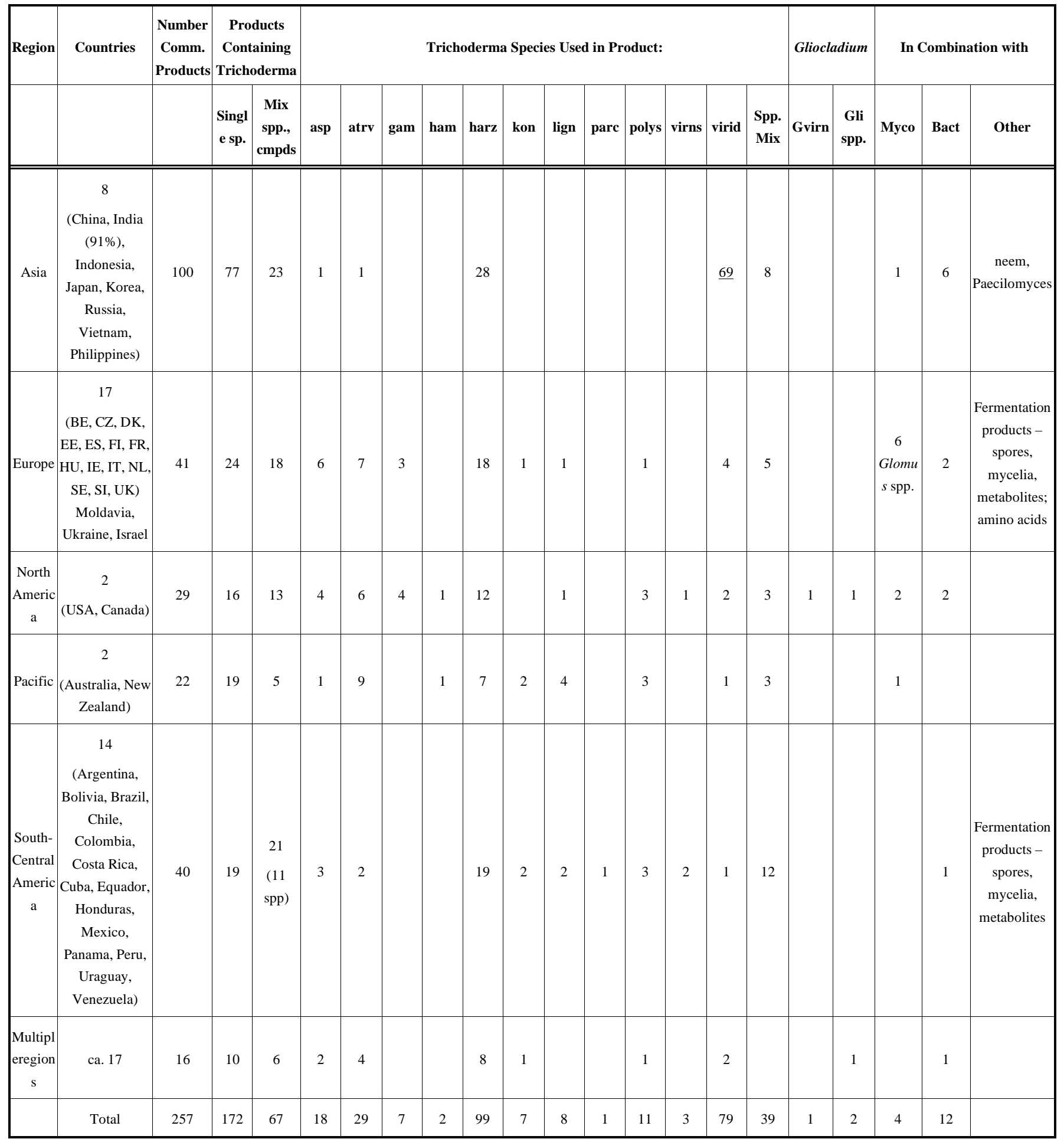

Mycorrhize - Glomus aggregatum, G. brazillanum, G. clarum, G. etunicatum, G. intraradices, G. mosseae, G. monosporum, Glomus spp., and Gigaspora margarita, Pisolithus tinctorius, Rhizopogon luteolus, $R$. fulvigleba, $R$. villosullus, $R$. amylopogon, Scleroderma citrinum and $S$. cepa

Bacteria - Azobacter chroacoccum, Bacillus subtilis, B. licheniformis, B. azotoformans, B. megaterium, B. coagulans, B. pumilis, B. thuringiensis, Bradyrhizobium japonicum, Paeni Bacillus durum, P. polymyxa, Pseudomonas aureofacens, Ps. fluorescens, Saccharomyces cervisiae, Streptomyces griseus and $S$. lydicus;

Other. - chitosan, neem; Fermentation products-spores, mycelia and metabolites; amino acids; Paecilomyces lilacinus

T. lignorum, T. parceanamosum, T. polysporum, T. virens, T. viride and Trichoderma spp. There are also products that contain G. virens and Gliocladium spp. mixtures. Probably, the taxonomic identity of the species needs to be verified in the advent of various molecular methods and information available for classification $[31,98,99]$ The species that is used most frequently in the biological products and marketed worldwide is T. harzianum. This widespread distribution can also be attributed for instance to the great success and commercialization of a few given species-isolates that are 
found in exclusive products circulated on the international market. $T$. viride is a species that is largely used as a BCA in Asia, in particular in India where it is found in almost $70 \%$ of the available products.

The majority of biological products with different combinations of Trichoderma includes the species T. harzianum (83\%), of which $55 \%$ of these are combined with $T$. viride and $28 \%$ are with $T$. koningii (Table 4). One company uses a mix of T. asperellum and T. gamsii in five diverse products. Thirty-three formulations contain a mix of Trichoderma species, but the taxonomic identity is not indicated. Other microorganisms used in product mixtures are endomycorrhizes such as Glomus aggregatum, G. brazillanum, G. clarum, G. etunicatum, G. intraradices, G. mosseae, G. monosporum, Glomus spp., and Gigaspora margarita; and ectomycorrhize such as Pisolithus tinctorius, Rhizopogon luteolus, $R$. fulvigleba, $R$. villosullus, $R$. amylopogon, Scleroderma citrinum and $S$. cepa; beneficial bacteria, yeasts, streptomycetes consisting of Azobacter chroacoccum, Bacillus subtilis, B. licheniformis, B. azotoformans, B. megaterium, B. coagulans, B. pumilis, B. thuringiensis, Bradyrhizobium japonicum, PaeniBacillus durum, P. polymyxa, Pseudomonas aureofacens, Ps. fluorescens, Saccharomyces cervisiae, Streptomyces griseus,S. lydicus and a Paecilomyces lilacinus. A single product claims to contain 15 different species of mycorrhizal fungi, 11 different species of beneficial bacteria and 2 species of Trichoderma all in one. Compounds added for improved crop protection properties or enhanced biological activity of the formulation include chitosan, neem and amino acids. Furthermore, two liquid products contain Trichoderma spores, mycelia and culture fermentation broth that includes a mix of enzymes and metabolites.

Trichoderma products are promoted as biopesticides, biofungicides, bioprotectants, bio-inoculants, bio-stimulants, bio-decomposers, bio-fertilizers, plant growth promoters etc. In general, in agriculture worldwide, there is an enormous disparity between the actual number of BCAs in use and the number of BCAs that are registered. In fact, the main reason that BCAs are less used in Europe than in many other parts of the world is because the registration process is long and costly, even when the active principle is generally regarded as being safe [100]. In 2010, only 14 microbial species were listed in Annex I (according to 91/414/EEC), of which 5 were species of Trichoderma and one of Gliocladium. It is not surprising to note that the largest commercial distribution of biologicals occurs in countries where there are simplified registration procedures. However, to be admitted for commercialization, it is important that bio-pesticides are evaluated by appointed agencies that can estimate the risk assessment to human health and the environment to an appropriate extent

The majority of Trichoderma-containing products on the market make claims to be fungicidal $(64.8 \%$, Table 1), to be used mainly for the biological control of root diseases for preventative and/or curative control of soilborne pathogens such as Rhizoctonia, Pythium, Fusarium, Verticillium, Sclerotinia, Phytophthora etc. (Appendix I). Additionally, the fungicidal characteristics are used for the control of foliar diseases, protection of pruning wounds, wood and root decay caused by Botrytis, Chondrostereum, Heterobasidon, Armillaria, Eutypa etc. Many of these crop protection products are approved for use in organic farming in diverse countries. Other label claims include the use of Trichoderma as: a biostimulant or bioactivator $(3.3 \%)$ for improved seed germination or transplant establishment, an agent for plant and root growth promotion or enhancement and improved yield; a biofertilizer or soil amendment-integrator (2.9\%) that increases solubilization, uptake and assimilation of nutrients by the plant; an activator of plant defence mechanisms with induced systemic resistance (ISR, $0.4 \%$ ) to biotic and abiotic stresses. Some products with Trichoderma also claim to be efficient in the control of nematodes and insects, but this may be due to combinations with other fungal species that are also antagonistic to these pathogens in some cases. Trichoderma BCA's are applied in the field, nursery, greenhouse, turfgrass (golf courses) and home gardens; on a plethora of crops: cereals, legumes, oilseeds, sugarcane, forages, horticulture, ornamental, spices, fruit orchards, ornamental trees, vineyards, interior plants. Furthermore, Trichoderma is indicated as a decomposer and humus/organic matter builder. The product claims are also multiple, consisting in various combinations of the above characteristics, i.e. fungicide and growth stimulator $(11.4 \%)$, fungicide, growth stimulator, fertilizer and ISR (4.0\%), fungicide, growth stimulator and fertilizer (4.4\%).

Most Trichoderma formulations are commercialized as wettable powders (WP, 55.3\%) that comprises of a given concentration of dried fungal conidia spores in a fine dust to be mixed with water (Table 1, Appendix I). One powder preparation is particular because the product is intended for delivery to flowers by using bees. The next commonly used formulations are granular (13.6\%), liquid (10.3\%), and solids $(6.2 \%)$ that include substrates such as a coco mat or peat moss, cereal grains such as rice, or broken corn that support the growth of a Trichoderma culture until sporulation. A unique system uses dowels impregnated with Trichoderma for insertion into holes drilled into the tree or grapevine trunk, providing systemic protection in response to plant stress for 4-5 yrs. Other products consist of emulsions, concentrated liquid suspensions, dry flowable, pellets, powder or talc. The WP, granules, emulsions, suspensions of Trichoderma are added to water and mixed for applications such as spray (ground and aerial), root drench, dip, seed treatment, irrigation, hydroponics; whereas the pellets, dry flowables and solid formulations are ready-to-use, and directly applied, for example to the soil by incorporation at time of seeding or transplant.

It should also be noted that in many instances the use of Trichoderma in agricultural production is not limited to those products found on the commercial market, but are a result of in-house or on-the-farm production use, with localized distribution [45]. Fungal spores can be produced in solid state fermentation on sterile rice, corn or other grains, and then the biopesticide can be applied directly to the crops or soil by using the Trichoderma-colonized substrate or the spores can be separated from the seed support by sifting and re-suspending in water. Another technique involves the production of Trichoderma in liquid fermentation, whereby a 
Table 4. Commercial biological products found on the worldwide market that contain combinations of different Trichoderma species, other microbial beneficials and/or other compounds, including product name and manufacturer ${ }^{1}$.

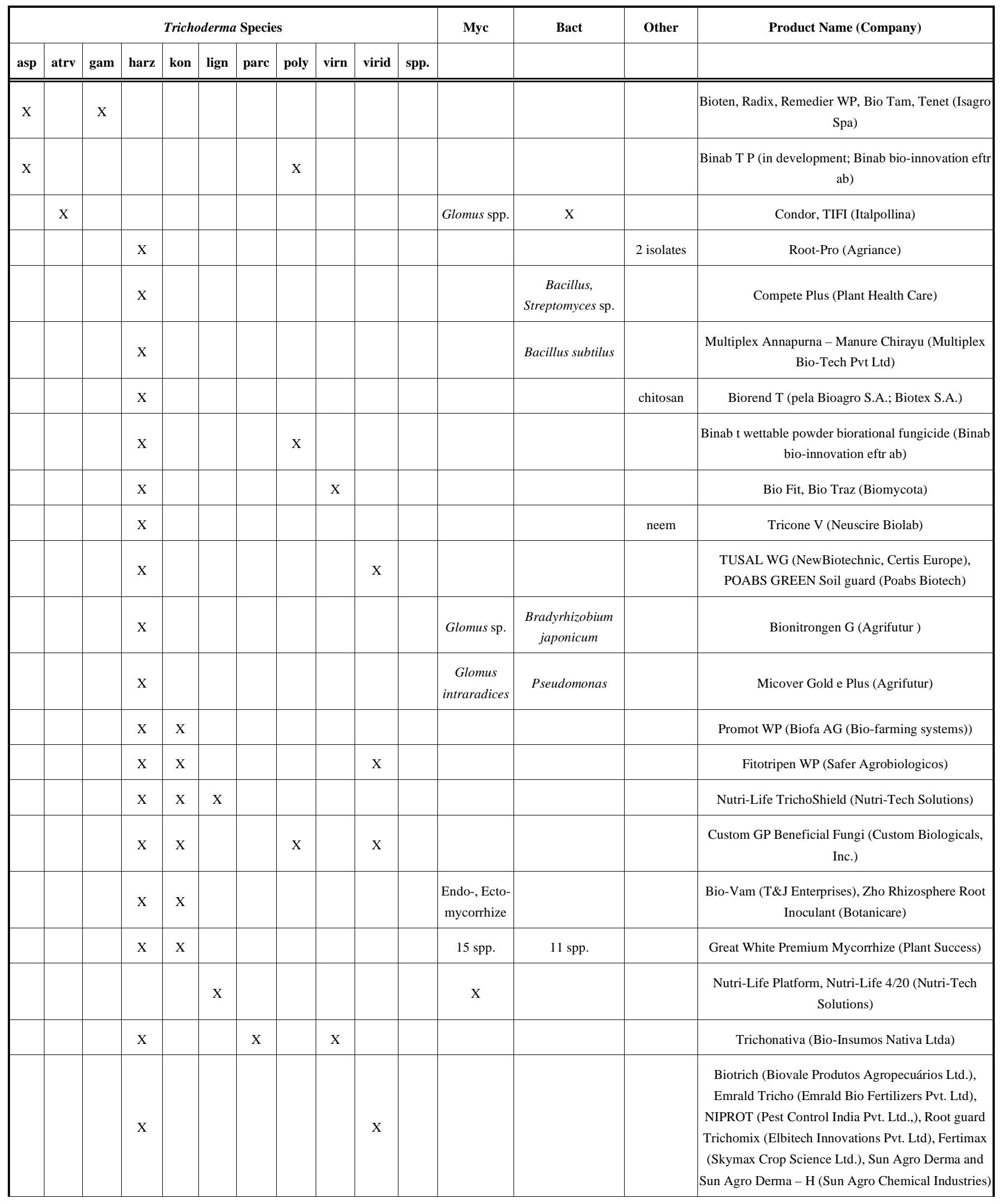


Table 4. contd...

\begin{tabular}{|c|c|c|c|c|c|c|c|c|c|c|c|c|c|c|}
\hline \multicolumn{11}{|c|}{ Trichoderma Species } & \multirow[t]{2}{*}{ Myc } & \multirow[t]{2}{*}{ Bact } & \multirow[t]{2}{*}{ Other } & \multirow[t]{2}{*}{ Product Name (Company) } \\
\hline asp & atrv & gam & harz & kon & lign & parc & poly & virn & virid & spp. & & & & \\
\hline & & & & & & & & & $\mathrm{x}$ & & $\mathrm{x}$ & & & Ayush (K. N. Bio Sciences Pvt. Ltd) \\
\hline & & & & & & & & & $\mathrm{X}$ & & & $\begin{array}{l}\text { Pseudomonas } \\
\text { fluorescens }\end{array}$ & & ANOKA (K. N. Bio Sciences Pvt. Ltd) \\
\hline & & & $\mathrm{X}$ & & & & & & $\mathrm{x}$ & & & & $\begin{array}{c}\text { Paecilomyces } \\
\text { lilacinus }\end{array}$ & Shakti-AG (Nivshakti Bioenergy Pvt. Ltd.) \\
\hline & & & $\mathrm{x}$ & & & & & & $\mathrm{X}$ & & & $\begin{array}{l}\text { Pseudomonas } \\
\text { fluorescens, } \\
\text { Bacillus subtilis }\end{array}$ & & Bio Protector (Bacto Agro Culture Care Pvt. Ltd) \\
\hline & & & $\mathrm{x}$ & $\mathrm{x}$ & & & & & $\mathrm{x}$ & $\mathrm{X}$ & & & & ICB Nutrisolo SC e WP (ICB BIOAGRITEC Ltd) \\
\hline & & & & & & & & & $\mathrm{x}$ & & & & & $\begin{array}{l}\text { Bio-Tricure (Chaitra Fertilizers \& Chemicals Pvt. } \\
\text { Ltd) }\end{array}$ \\
\hline & & & & & & & & & & $\mathrm{X}$ & & $\begin{array}{l}\text { Bacillus spp., } \\
\text { PaeniBacillus }\end{array}$ & & BiotaMax (CustomBio) \\
\hline & & & & & & & & & & $\mathrm{x}$ & & & $\begin{array}{c}\text { fermentation } \\
\text { products, } \\
\text { amino acids }\end{array}$ & $\begin{array}{l}\text { Sani-Root (AMC Chemical, S.L .and Trichodex, } \\
\text { S.A.) }\end{array}$ \\
\hline & & & & & & & & & & $\mathrm{X}$ & & & & $\begin{array}{c}\text { Biagro TL (Bioagro), Bio Sol Tricho (Biological } \\
\text { Solutions Ltd), CANNA AkTRivator (CANNA), } \\
\text { DRH Trichoderma Products (GroChem NZ Ltd.), } \\
\text { Excalibur (ABM), Oregonism XL Root Organics } \\
\text { (Aurora Innovations), T. viride / harzianum (Dr. } \\
\text { Rajan Laboratories), Tricho Plus (Biological Control } \\
\text { Products Pty Ltd), Trichodel (Empresa Caxiense de } \\
\text { Controle Biológico Ltda), Trichoderma (Boothankad } \\
\text { Estate), Trichoderma Fungicide (Vedanta Organo } \\
\text { World), Trichomax (SolAgro, Trujillo), Trichonat } \\
\text { (Natural Rural), Trichoteam (Bioteam Ind. e Com. } \\
\text { Ltda.), Trichozam (Hardware \& Lumber Limited - } \\
\text { Agro Grace Division), Tricodamp (Productividad } \\
\text { Biosfera Medio Ambiente - Probioma), Bactiva } \\
\text { (Tecnologias Naturales Internacional), Trichosav-55 } \\
\text { (Institute for Research in Plant Protection, CANNA } \\
\text { Coco (CANNA), Trichoplus JCO ( JCO Indústria e } \\
\text { Comércio de Fertilizantes LTD), TB62 Trichoderma: } \\
\text { Biofungicide for vegetables (Philippine Rice } \\
\text { Research Institute), Biospark Trichoderma (Biospark } \\
\text { Corp.), Solstice (Metcalf Biologicals) }\end{array}$ \\
\hline & & & & & & & & & & $\mathrm{X}$ & $\mathrm{X}$ & $\mathrm{X}$ & $\begin{array}{c}\text { fermentation } \\
\text { products }\end{array}$ & BioPlantguard (Saipan srl) \\
\hline & & & & & & & & & & $\mathrm{x}$ & & $\begin{array}{l}\text { Bacillus spp. } \\
\text { PaeniBacillus }\end{array}$ & & Bio Max Soil Probiotic (Custom Biologicals, Inc.) \\
\hline & & & & & & & & & & $\mathrm{X}$ & $\mathrm{X}$ & Bacillus & & TNC Mycorr -Max, Hydro (The Nutrient Company) \\
\hline & & & & & & & & & & $\mathrm{x}$ & & Bacillus & & $\begin{array}{l}\text { Agrotrich e Agrotrich Plus (Agrosafra Sementes), } \\
\text { Bactiva (Tecnologias Naturales Internacional) }\end{array}$ \\
\hline
\end{tabular}


Table 4. contd...

\begin{tabular}{|l|l|l|l|l|l|l|l|l|l|l|l|l|l|l|}
\hline \multicolumn{9}{|c|}{ Trichoderma Species } & Myc & Bact & Other & Product Name (Company) \\
\hline asp & atrv & gam & harz & kon & lign & parc & poly & virn & virid & spp. & & & & \\
\hline \hline & & & & & & & & & & $\mathrm{X}$ & & Azotobacter & & $\begin{array}{c}\text { PSB SSB Trichoderma Azotobacter (Divya Pruthvi } \\
\text { Enterprises) }\end{array}$ \\
\hline
\end{tabular}

${ }^{1}$ Note: indications of any commercial products by the authors does not by anyway indicate an endorsement of the product or company

Trichoderma species present (as indicated on the label) - T. asperellum (asp), T. atroviride (atrv), T. gamsii (gam), T. hamatum (ham), T. harzianum (harz), T. koningii (kon), T. lignorum (lign), T. parceanamosum (parc), T. polysporum (polys), T. virens (virns), T. viride (virid), T. species mix (spp.).

Mycorrhize - Glomus sp. or spp. (species not specified), G. intraradices; Endo-, Ecto-mycorrhize (not specified)

Bacteria - Azobacter chroacoccum, Bacillus subtilis, B. licheniformis, B. azotoformans, B. megaterium, B. coagulans, B. pumilis, B. thuringiensis, Bradyrhizobium japonicum, PaeniBacillus durum, P. polymyxa, Pseudomonas aureofacens, Ps. fluorescens, Saccharomyces cervisiae, Streptomyces griseus and S. lydicus;

Other. - chitosan, neem; Fermentation products-spores, mycelia and metabolites; amino acids; Paecilomyces lilacinus

culture is produced that containing spores, mycelia, lytic enzymes, metabolites etc., and this fungal mixture is directly applied in the field for biological control. In some countries, such as Venezuela and Cuba, the development and use of Trichoderma-based bioproducts is Government-supported and officially endorsed for use in agriculture [45].

Generally Trichoderma bio-products on the agricultural market have been selected by using "old" methods and criteria of classical biological control. The products have been applied to plants indiscriminately without an appropriate knowledge of the mechanisms of action used by the fungus for disease control. Further, due to insufficient examination, many products have demonstrated problems with reliability and reproducibility in the field, inappropriate formulations, inadequate quality control etc.

The genetic diversity within the genus Trichoderma is very high, thus the multitude of useful characteristics for biological applications in agriculture and industry is far from being fully exploited, and requires thorough assessment. A method needs to be employed to select multi-action fungal strains to be tested in the field. Some considerations include the ability to: 1) control plant disease pathogens - a good mycoparasite and/or producer of lytic enzymes; 2) increase plant systemic resistance to biotic and abiotic stresses [57]; 3) promote plant/root growth and development in order to boost yields; 4) persist in the rhizosphere, and eventually be endophytic; 5) produce specific compounds (i.e. secondary metabolites) that affect negatively the pathogen and positively the plant; 6 ) degrades pollutants in the soil, thus helping in bonificating contaminated environments; 7) solubilise, sequester, allocate nutrients to the plant, 8) be compatible or synergistic with agro-chemicals commonly used, and other biocontrol agents; 9) maintain efficacy in the formulation processes, being a prolific spore/cfu producer in industrial fermentation conditions [57]. Modern scientific technology provides the possibility to conduct pre-field selection for suitable BCAs based on various studied genetic and biochemical characters known to be involved in the biological processes important and useful for crop protection. Screening is performed on the microorganism extracts by using high throughput screening, analysis of the proteome, metabolome transcriptome and other 'omics, microbiome and metagenomic analysis of "stimulating" plant-microbe environments, whole genome next generation sequencing $[6,8,77,101,102]$. Based on known desirable characteristics, new strains can be designed and developed by using hybrid technology (i.e. protoplast fusion in the case of T. harzianum strain T22) for improvement of biological characteristics.

In order to be economically competitive on the commercial market, as well as equivalent to or superior in efficacy to chemical products, a further development of novel formulations of Trichoderma is necessary to satisfy these requirements. The costs of industrial production have been reduced substantially by using improved solid or liquid fermentation processes. Low cost substrates for producing pure fungal spores on grains such as rice, or recycled materials from the food manufacturing (material from flour milling, fibre from oil pressing, fruit peels etc.) are being used worldwide without the need for expensive high-tech equipment, for example, placing the inoculated substrate in plastic bags or trays, and processing without the need for highly trained workers and complex apparatus $[45,85]$. Or in alternative, fermentation is not focused only on obtaining a commercial product that contains pure spores, but generating a fungal culture in liquid that consists of a mix of spores, mycelia, cell wall degrading enzymes and other biologically active substances that form the natural arsenal of compounds used by Trichoderma to control phytopathogens and positively affect the plant. Furthermore, in order to maintain quality and viability during storage, research is focused on meeting the biological requirements of the BCA while minimizing the inconsistency of the results obtained in the field, attempts are being made to buffer the sensitivity of the $\mathrm{BCA}$ to the environmental conditions by improving strain selection and product formulations.

Clearly the positive biological effects of Trichoderma to the plant are being recognized not only in the laboratory, but also globally in the real agriculture crop production environment. This is acknowledged by the escalating number of products commercially available in the last decade [100], the expanded utilization in a greater diversity of crops, as well as the spread in geographic distribution. Our understanding of the mechanisms of biological control used by agents such as Trichoderma is continuously expanding. The use of modern laboratory techniques aids in the study and identification of the molecular activities that this fungus exploits during the interaction with other microbes and the plant [7, 8, 18, 103]. Ideal biological characters can be identified from selected species or isolates and utilized for biotechnological improvement of isolates and natural products there of $[5,8,103]$. This information can be subsequently employed to obtain the next generation products that are actively sought after by the agriculture 
market because of the new requirements for greater safety, higher yields and lower operating costs.

\section{CONFLICT OF INTEREST}

The authors confirm that this article content has no conflicts of interest.

\section{ACKNOWLEDGEMENTS}

Work by the authors FV and MR was supported by a dedicated grant from the Italian Ministry of Economy and Finance to the National Research Council for the project "Innovazione e Sviluppo del Mezzogiorno - Conoscenze
Integrate per Sostenibilità ed Innovazione del Made in Italy Agroalimentare - Legge n. 191/2009". Work by the authors FV, MR, SW, ML, MN, RM, NL, AP, SL and GM has been supported by the following projects: Calabria Region APQ Projects "S.Re.Va.Pr.O.", Mis. 124, Projects "CA.SVI.PR.OLI." and "MI.P.RE.VEGE."; PRIN MIUR 2008 prot. 2008SNPNC2 - prot. 2008WKPAWW; FIRB 2002 prot. RBNE01K2E7; PRIN 2003 prot. 2003070719-003, MIUR PON project no. DD12935 of 02/08/2002; MIUR PON project no. DD1219 of 05/10/2004; MIUR PON project no. DD1801 of 31/12/2004; MIUR PON project no. DD29156 of 20/04/2011; EU TRICHOEST QLK3-2002-02032; EU 2E-BCAs IN CROPS FOOD-CT-2003-001687; EU PURE FP7-KBBE-2010-4. Miur 2007-2013 Genepom-Pro PON02-00395-3082360.

Appendix 1. Biological products found on the international market that contain Trichoderma and Gliocladium, as determined by a survey on internet. References are made to the product name, manufacturer/distributor, geographical regions and the countries where the product is available, and if it is registered (anywhere in the world). General characteristics according to information specified for each product (if designated): Trichoderma, Gliocladium, other microbes or compounds included; targeted uses, label claims for application, such as mode of action, recommended crops and approved for organic farming; targeted pests controlled, a general group or specific pathogens; product formulation and application; label claims for use.

\begin{tabular}{|c|c|c|c|c|c|c|c|c|c|c|c|c|c|}
\hline \multirow[t]{2}{*}{ Product Name } & \multirow{2}{*}{$\begin{array}{c}\text { Company/Distribu } \\
\text { tor (website) }\end{array}$} & \multirow[t]{2}{*}{ Country $^{1}$} & \multirow{2}{*}{\begin{tabular}{|c|} 
Active \\
Substances \\
$\begin{array}{c}\text { Trichoderma, } \\
\text { Gliocladium } \\
\text { spp. }\end{array}$ \\
\end{tabular}} & \multirow[t]{2}{*}{ Registered $^{2}$} & \multirow{2}{*}{$\begin{array}{c}\text { Target Uses, Label } \\
\text { Claims, Recommended } \\
\text { Crops, Organic Farming } \\
\text { Approval Agency }^{3}\end{array}$} & \multirow[t]{2}{*}{ Target Pests } & \multirow[t]{2}{*}{ Formulation $^{4}$} & \multicolumn{6}{|c|}{ Product Claims for Use ${ }^{5}$} \\
\hline & & & & & & & & $\mathbf{F}$ & STIM & $\begin{array}{l}\text { FERT/ } \\
\text { NUTR }\end{array}$ & ISR & DEC & OTHER \\
\hline \multicolumn{14}{|l|}{ Africa } \\
\hline Bio-Tricho & $\begin{array}{c}\text { Agro-Organics } \\
\text { (http://www.agro- } \\
\text { organics.co.za/biotri } \\
\text { cho.php) }\end{array}$ & South Africa & $\begin{array}{l}\text { T. harzianum } \\
\text { strain SF }\end{array}$ & $R$ & Can be applied to all crops. & $\begin{array}{c}\text { Control Botrytis and } \\
\text { root diseases such as } \\
\text { Rhizoctonia, } \\
\text { Phytophthora, } \\
\text { Pythium, Fusarium, } \\
\text { etc. }\end{array}$ & WP & $\mathrm{F}$ & & & & & \\
\hline Eco-77 & $\begin{array}{c}\text { Plant Health } \\
\text { Products } \\
\text { (http://www.plant- } \\
\text { health.co.za/) }\end{array}$ & $\begin{array}{c}\text { R South } \\
\text { Africa; R in } \\
\text { process. } \\
\text { Kenya, } \\
\text { Zambia }\end{array}$ & $\begin{array}{l}\text { T. harzianum } \\
\text { strain B77 }\end{array}$ & $R$ & $\begin{array}{l}\text { Control of Botrytis in } \\
\text { zucchine, tomatoe and } \\
\text { roses; Eutypa in grapes }\end{array}$ & & WP & $\mathrm{F}$ & & & & & \\
\hline Eco-T & $\begin{array}{c}\text { Plant Health } \\
\text { Products (Pty)Ltd } \\
\text { (http://www.plant- } \\
\text { health.co.za) }\end{array}$ & \begin{tabular}{|c|} 
R South \\
Africa, \\
Kenya, \\
Zambia, FR, \\
UK, \\
Morocco, \\
Tunisia, India
\end{tabular} & $\begin{array}{c}\text { T. harzianum } \\
\text { strain kd }\end{array}$ & $R$ & $\begin{array}{c}\text { control of crop root } \\
\text { diseases and for enhanced } \\
\text { plant growth }\end{array}$ & $\begin{array}{c}\text { Rhizoctonia, } \\
\text { Pythium, Fusarium } \\
\text { and Phytophthora }\end{array}$ & $\begin{array}{l}\text { WP, seed trt, } \\
\text { irrigation }\end{array}$ & $\mathrm{F}$ & ST & & & & \\
\hline Promot WP & $\begin{array}{c}\text { Biofa AG (Bio- } \\
\text { farming systems) - } \\
\text { http://www.biofa- } \\
\text { farming.de/ }\end{array}$ & $\begin{array}{c}\text { Kenya (temp. } \\
\text { 2010), R in } \\
\text { Germany }\end{array}$ & $\begin{array}{c}\text { T. harzianum, } T . \\
\text { koningii }\end{array}$ & $R$ & $\begin{array}{l}\text { Horticultural and } \\
\text { ornamental crops }\end{array}$ & $\begin{array}{l}\text { Control of damping- } \\
\text { off and root rot } \\
\text { caused by Pythium }\end{array}$ & WP & $\mathrm{F}$ & & & & & \\
\hline Romulus & $\begin{array}{l}\text { DAGUTAT } \\
\text { BIOLAB }\end{array}$ & South Africa & $\begin{array}{c}\text { T. harzianum } \\
\text { isolate DB } 104\end{array}$ & $R$ & $\begin{array}{l}\text { Stimulates root } \\
\text { development }\end{array}$ & & & & ST & & & & \\
\hline
\end{tabular}


Appendix 1. contd...

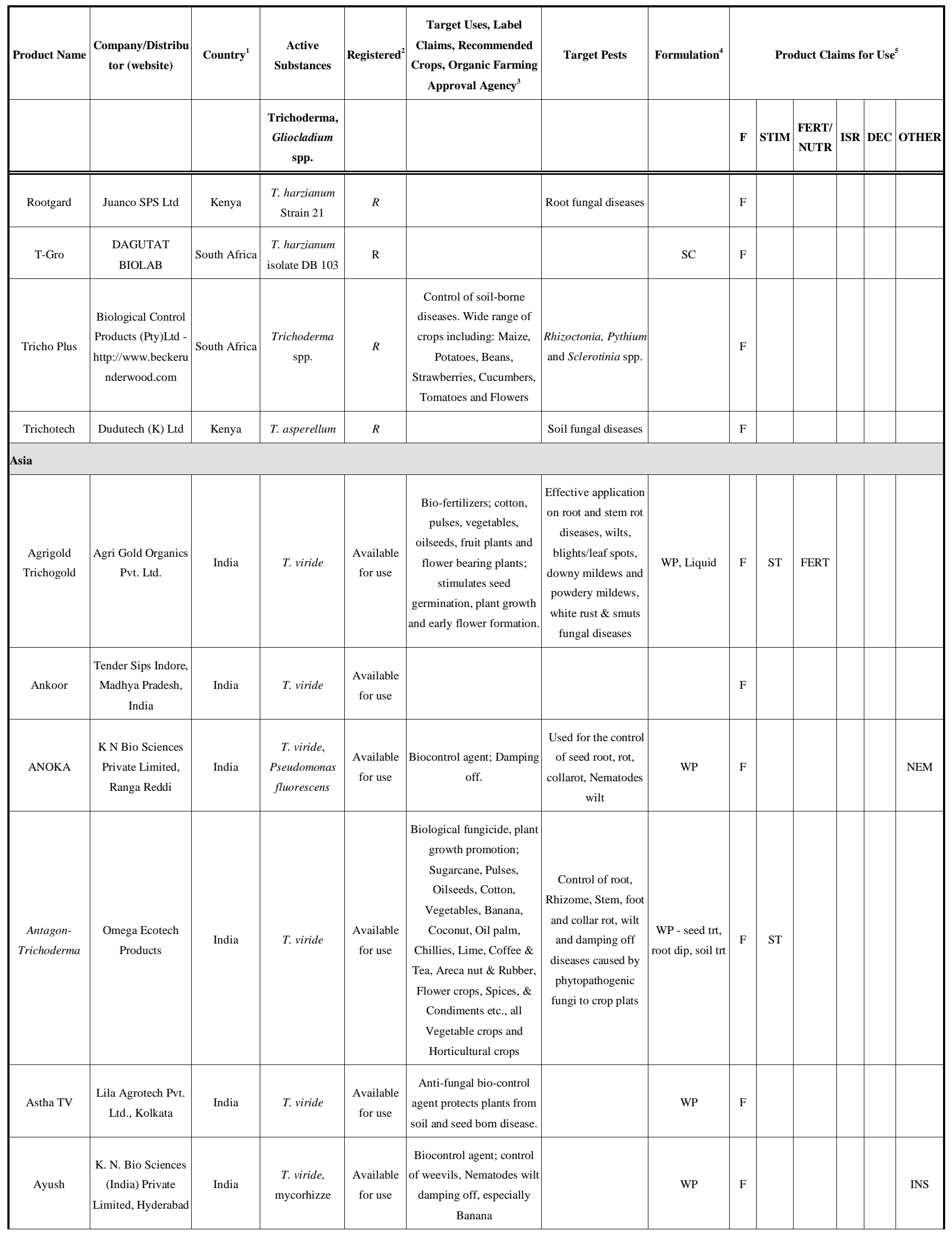


Appendix 1. contd...

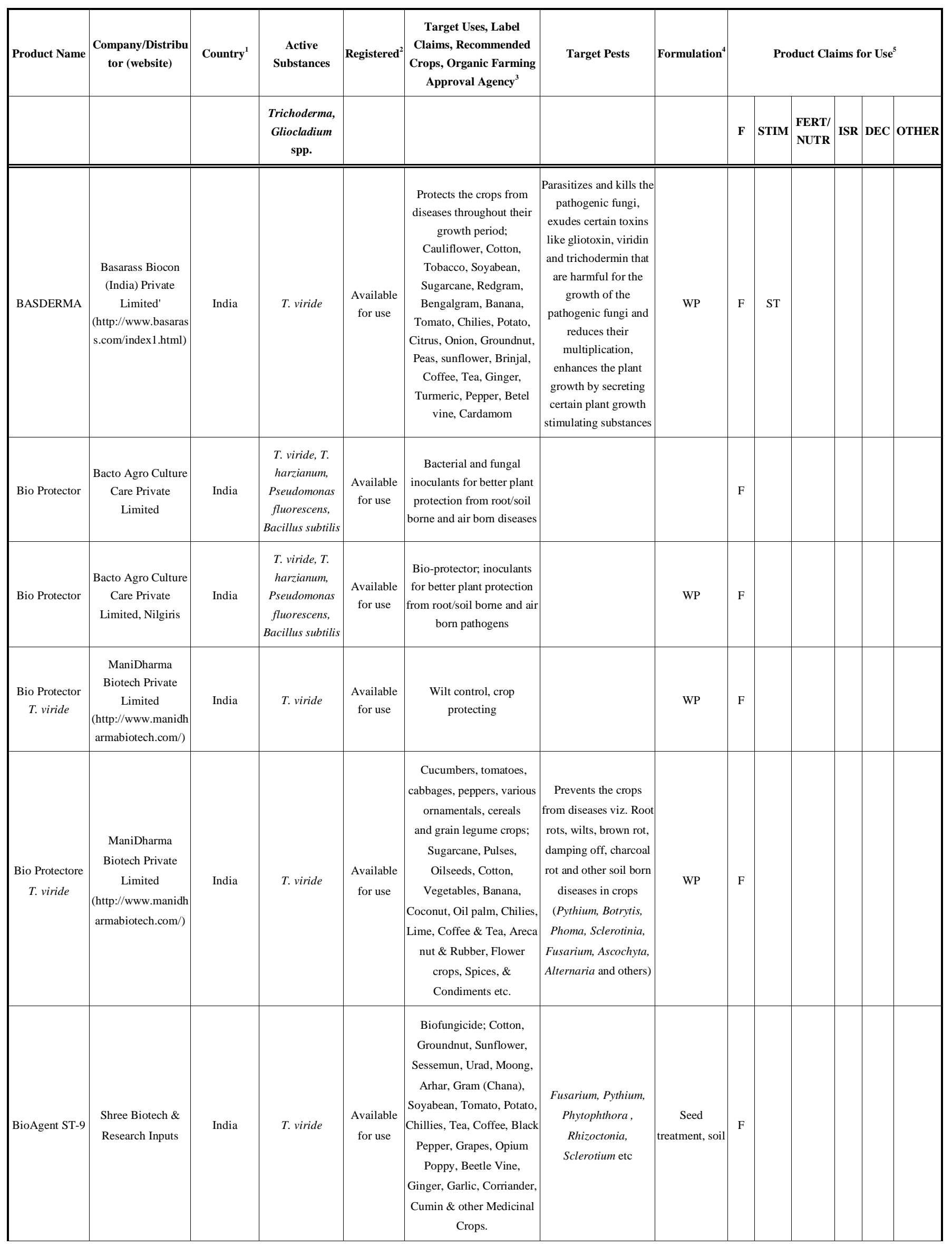


Appendix 1. contd...

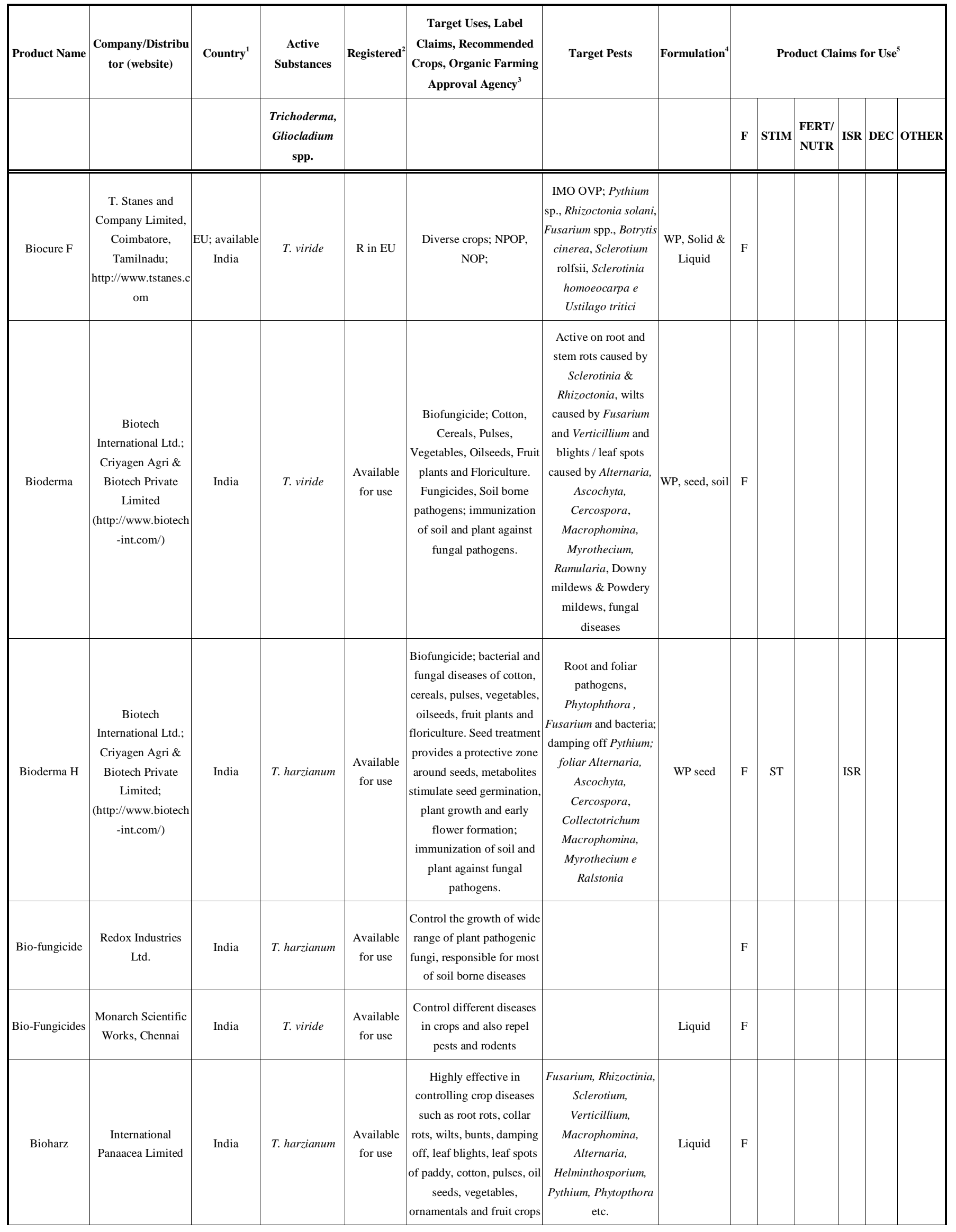


Appendix 1. contd...

\begin{tabular}{|c|c|c|c|c|c|c|c|c|c|c|c|c|c|}
\hline \multirow[t]{2}{*}{ Product Name } & \multirow[t]{2}{*}{$\begin{array}{c}\text { Company/Distribu } \\
\text { tor (website) }\end{array}$} & \multirow[t]{2}{*}{ Country $^{1}$} & \multirow{2}{*}{$\begin{array}{c}\text { Active } \\
\text { Substances } \\
\begin{array}{c}\text { Trichoderma, } \\
\text { Gliocladium } \\
\text { spp. }\end{array}\end{array}$} & \multirow[t]{2}{*}{ Registered $^{2}$} & \multirow{2}{*}{$\begin{array}{c}\text { Target Uses, Label } \\
\text { Claims, Recommended } \\
\text { Crops, Organic Farming } \\
\text { Approval Agency }^{3}\end{array}$} & \multirow[t]{2}{*}{ Target Pests } & \multirow[t]{2}{*}{ Formulation $^{4}$} & \multicolumn{6}{|c|}{ Product Claims for Use ${ }^{5}$} \\
\hline & & & & & & & & $\mathbf{F}$ & STIM & $\begin{array}{l}\text { FERT/ } \\
\text { NUTR }\end{array}$ & ISR & DEC & OTHER \\
\hline Biohit & $\begin{array}{c}\text { Indore Biotech } \\
\text { Inputs \& Research } \\
\text { Private Limited }\end{array}$ & India & T. viride & $\begin{array}{l}\text { Available } \\
\text { for use }\end{array}$ & $\begin{array}{l}\text { Fungicides, Soil borne } \\
\text { pathogens }\end{array}$ & & WP & $\mathrm{F}$ & & & & & \\
\hline Bio-Shield & $\begin{array}{c}\text { Ambika Biotech ( } \\
\text { (http://www.indiam } \\
\text { art.com/ambikabiote } \\
\text { ch/) }\end{array}$ & India & T. viride & $\begin{array}{c}\text { Available } \\
\text { for use }\end{array}$ & $\begin{array}{c}\text { Cotton, Groundnut, } \\
\text { Sunflower, Sessemun, } \\
\text { Urad, Moong, Arhar, Gram } \\
\text { (Chana), Soyabean, } \\
\text { Tomato, Potato, Chillies, } \\
\text { Tea, Coffee, Black Pepper, } \\
\text { Grapes, Opium Poppy, } \\
\text { Beetle Vine, Ginger, } \\
\text { Garlic, Corriander, Cumin } \\
\text { and other Medicinal Crops }\end{array}$ & $\begin{array}{l}\text { Used against seed born } \\
\text { plant pathogenic fungi, } \\
\text { e.g. Fusarium, } \\
\text { Pythium, Phytophthora } \\
\text {, Rhizoctonia, } \\
\text { Sclerotium etc. }\end{array}$ & WP & $\mathrm{F}$ & & & & & \\
\hline \begin{tabular}{c|} 
Biospark \\
Trichoderma
\end{tabular} & $\begin{array}{c}\text { Biospark Corp. } \\
\text { (http://www.biospar } \\
\text { kph.com/annual- } \\
\text { product-revenue- } \\
\text { goal) }\end{array}$ & Philippines & $\begin{array}{l}\text { Trichoderma } \\
\text { spp.; three } \\
\text { tropical fungi } \\
\text { strains isolated } \\
\text { from the } \\
\text { Philippine } \\
\text { forests }\end{array}$ & $\begin{array}{c}\text { Available } \\
\text { for use }\end{array}$ & $\begin{array}{c}\text { Biofertilizer, biofungicide, } \\
\text { growth promotant, and } \\
\text { composting agent; rice, } \\
\text { corn, vegetables, mango, } \\
\text { durian horticulture, } \\
\text { decomposing agent }\end{array}$ & & $\mathrm{Wp}$ & $\mathrm{F}$ & ST & FERT & & DEC & \\
\hline Biostar & \begin{tabular}{|c|} 
Peak Chemical \\
Industries Limited, \\
Siliguri, West \\
Bengal
\end{tabular} & India & T. viride & $\begin{array}{c}\text { Available } \\
\text { for use }\end{array}$ & NPOP, NOP; IMO OVP & & $\begin{array}{c}\text { Liquid \& } \\
\text { Powder }\end{array}$ & $\mathrm{F}$ & & & & & \\
\hline BiotaMax & \begin{tabular}{|c|} 
CustomBio \\
(http://custombio- \\
indonesia.com/biota \\
max)
\end{tabular} & Indonesia & $\begin{array}{c}\text { Trichderma spp. } \\
\text { (4), Bacillus spp. } \\
\text { (5), } \\
\text { PaeniBacillus }\end{array}$ & $\begin{array}{c}\text { Available } \\
\text { for use }\end{array}$ & Soil probiotic & & & & & FERT & & & \\
\hline Bio-Tricure & $\begin{array}{c}\text { Chaitra Fertilizers \& } \\
\text { Chemicals Private } \\
\text { Limited }\end{array}$ & India & $\begin{array}{l}\text { T. viride } \\
\text { included }\end{array}$ & $\begin{array}{c}\text { Available } \\
\text { for use }\end{array}$ & $\begin{array}{c}\text { Biopesticide; fungal } \\
\text { diseases of Cotton, } \\
\text { Tobacco, Cereals, Pulses, } \\
\text { Vegetables, Oilseeds, Fruit } \\
\text { plants and Floriculture }\end{array}$ & $\begin{array}{c}\text { Root and stem rots by } \\
\text { Sclerotinia } \text { and } \\
\text { Rhizoctonia, wilts by } \\
\text { Fusarium and } \\
\text { Verticillium, blights or } \\
\text { leaf spots caused by } \\
\text { Alternaria, Ascochyta, } \\
\text { Cercospora, } \\
\text { Macrophomina, } \\
\text { Myrothecium, } \\
\text { Ramularia; effective } \\
\text { over Downy mildews } \\
\text { and Powdery mildews, } \\
\text { and fungal diseases of } \\
\text { Cotton }\end{array}$ & WP & $\mathrm{F}$ & & & & & \\
\hline
\end{tabular}


Appendix 1. contd...

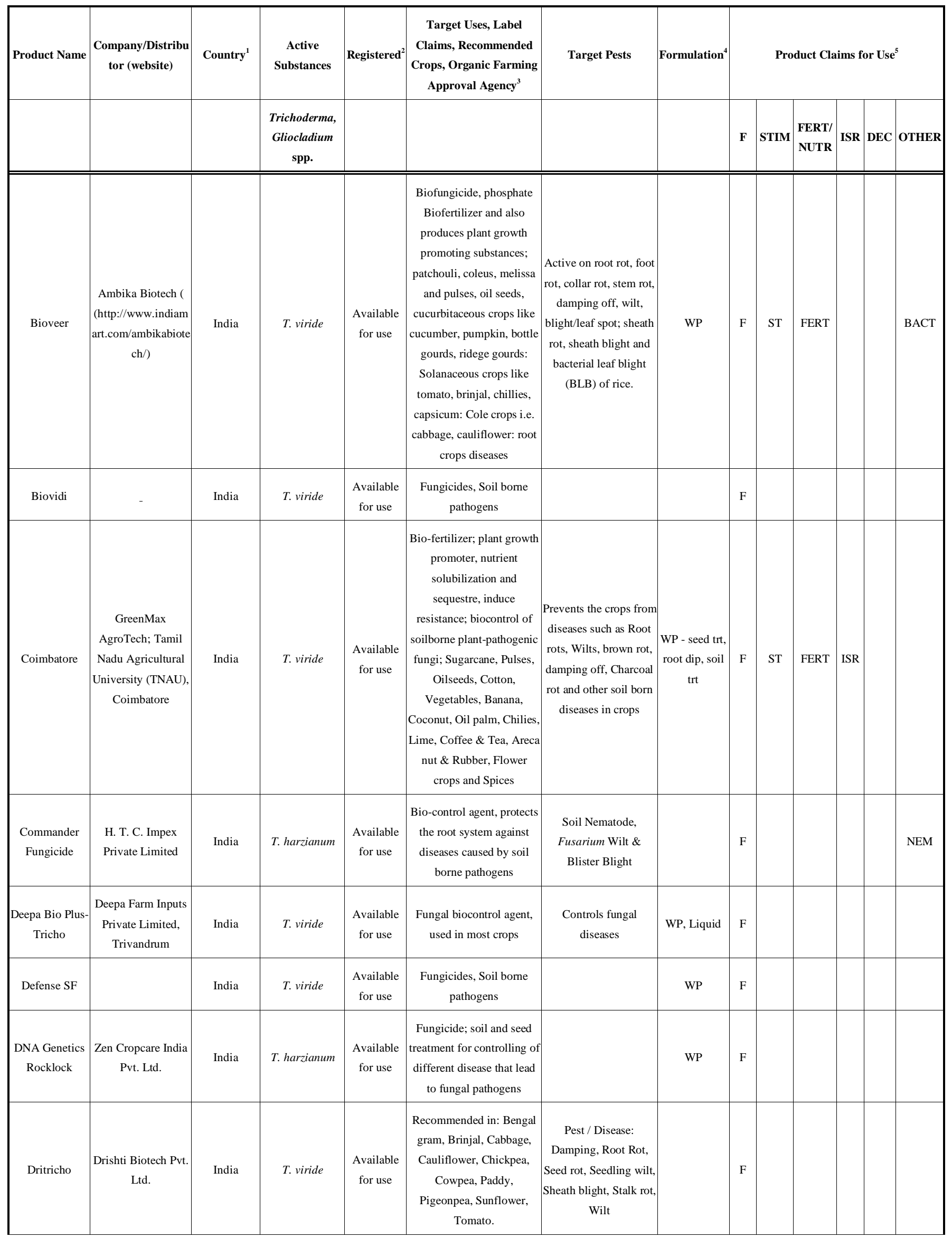


Appendix 1. contd...

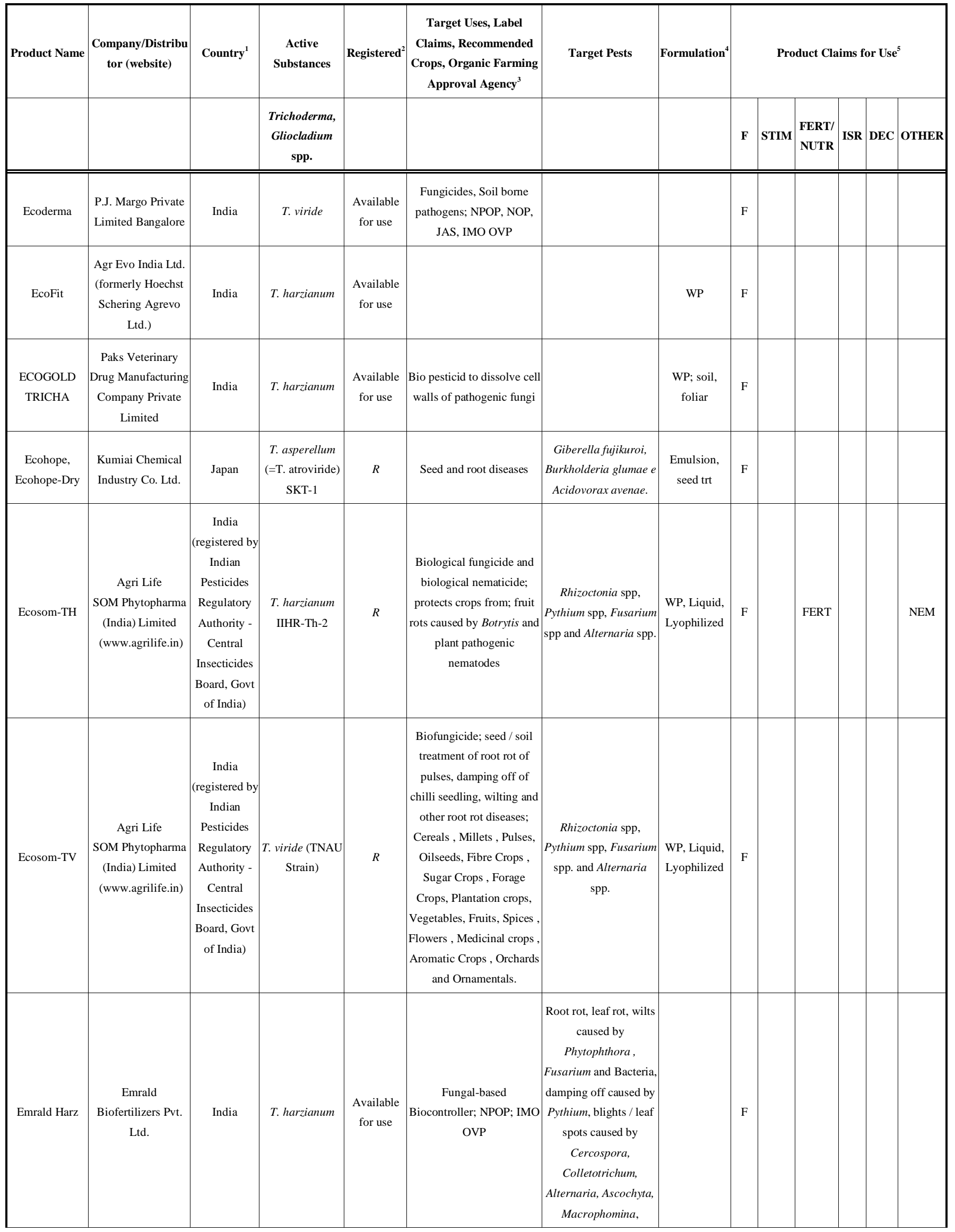


Appendix 1. contd...

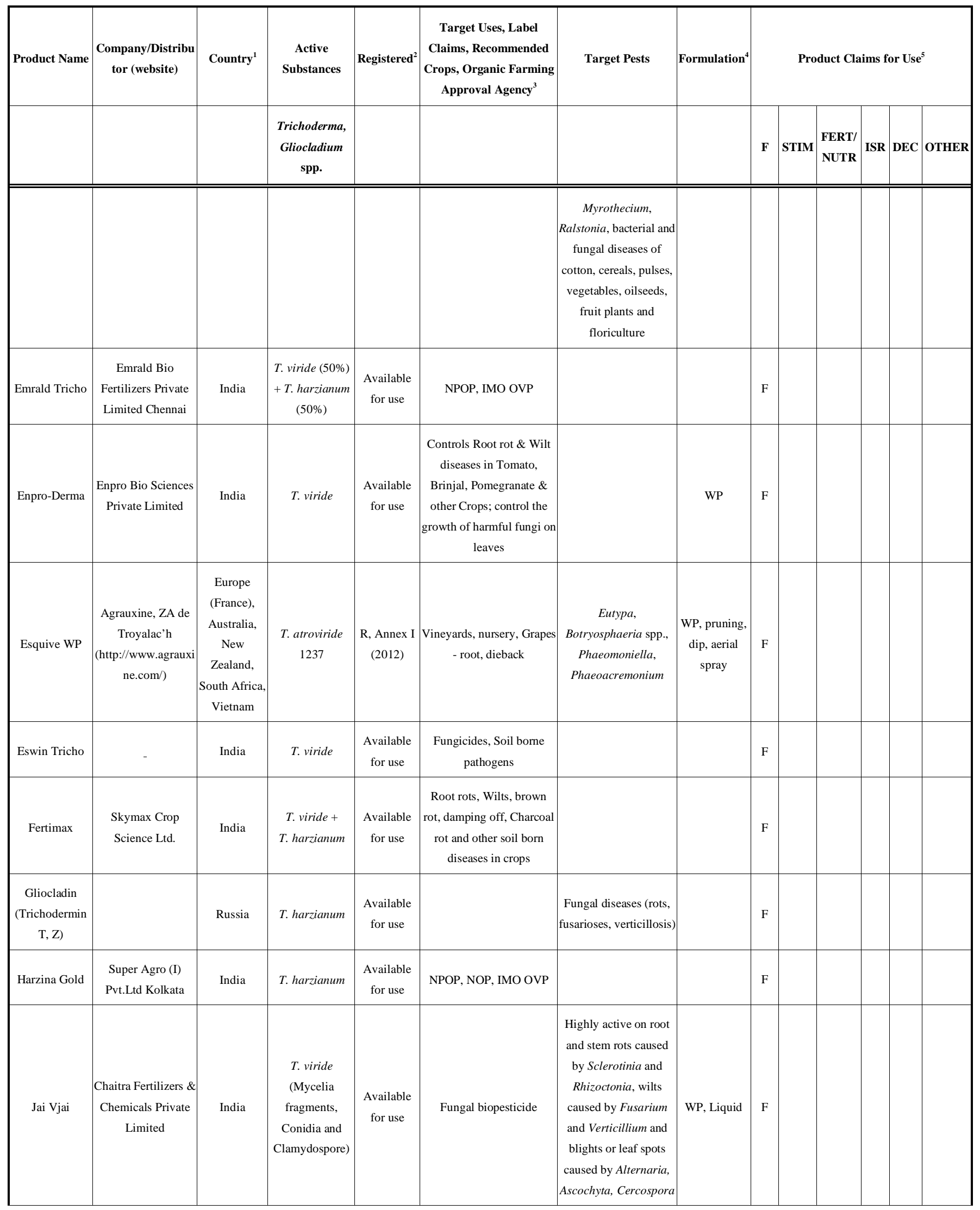


Appendix 1. contd...

\begin{tabular}{|c|c|c|c|c|c|c|c|c|c|c|c|c|c|}
\hline \multirow[t]{2}{*}{ Product Name } & \multirow[t]{2}{*}{$\begin{array}{c}\text { Company/Distribu } \\
\text { tor (website) }\end{array}$} & \multirow[t]{2}{*}{ Country $^{1}$} & \multirow{2}{*}{$\begin{array}{c}\text { Active } \\
\text { Substances } \\
\begin{array}{c}\text { Trichoderma, } \\
\text { Gliocladium } \\
\text { spp. }\end{array}\end{array}$} & \multirow[t]{2}{*}{ Registered } & \multirow{2}{*}{$\begin{array}{c}\text { Target Uses, Label } \\
\text { Claims, Recommended } \\
\text { Crops, Organic Farming } \\
\text { Approval Agency }\end{array}$} & \multirow[t]{2}{*}{ Target Pests } & \multirow[t]{2}{*}{ Formulation $^{4}$} & \multicolumn{6}{|c|}{ Product Claims for Use $\mathrm{U}^{5}$} \\
\hline & & & & & & & & $\mathbf{F}$ & STIM & 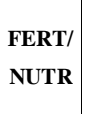 & ISR & DEC & OTHER \\
\hline $\begin{array}{c}\text { Krishi } \\
\text { Bio.Nidan }\end{array}$ & $\begin{array}{c}\text { Krishi Bio Products } \\
\& \text { Research Private } \\
\text { Limited }\end{array}$ & India & T. viride & $\begin{array}{l}\text { Available } \\
\text { for use }\end{array}$ & $\begin{array}{c}\text { Plant diseases antagonistic } \\
\text { fungus; }\end{array}$ & $\begin{array}{c}\text { Soil borne plant } \\
\text { pathogens like } \\
\text { Fusarium, Rhizoctonia, } \\
\text { Pythium and others }\end{array}$ & $\begin{array}{c}\text { Seed soil } \\
\text { application, } \\
\text { seedlings root } \\
\text { dip treatment }\end{array}$ & $\mathrm{F}$ & & & & & \\
\hline $\begin{array}{l}\text { Monitor- } T \text {. } \\
\text { viride }\end{array}$ & $\begin{array}{c}\text { Agriland Biotech } \\
\text { Limited; } \\
\text { manufactured by } \\
\text { Surface Technology }\end{array}$ & India & T. viride & $\begin{array}{l}\text { Available } \\
\text { for use }\end{array}$ & $\begin{array}{c}\text { Biofungicide that works } \\
\text { against wilts and rots } \\
\text { diseases, realizes role of } \\
\text { biological crop protection; } \\
\text { decomposes raw organic } \\
\text { farm wastes, solubilizes } \\
\text { soil phosphorus, reclaims } \\
\text { adverse soils, promotes } \\
\text { plant growth and protects } \\
\text { soil eco-system }\end{array}$ & & WP & $\mathrm{F}$ & ST & FERT & & DEC & \\
\hline $\begin{array}{c}\text { NEEMODERM } \\
\mathrm{A}\end{array}$ & \begin{tabular}{|c|} 
Shri Ram Solvent \\
Extraction Private, \\
Ltd, Jaspur, India
\end{tabular} & India & $\begin{array}{c}\text { T. viride/ } \\
\text { T.harzianium }\end{array}$ & $\begin{array}{l}\text { Available } \\
\text { for use }\end{array}$ & $\begin{array}{c}\text { Biological fungicide; } \\
\text { highly effective control of } \\
\text { root/collar /stem rots, wilts, } \\
\text { damping offs, leaf blights } \\
\text { on cotton, pulses, oilseeds, } \\
\text { vegetables, floriculture are } \\
\text { fruit crops; stimulates the } \\
\text { plant growth resulting in } \\
\text { increase seed germination } \\
\text { \& healthy growth of } \\
\text { seedling \& plants }\end{array}$ & $\begin{array}{c}\text { Fusarium, Verticillium, } \\
\text { Rhizooctonia, } \\
\text { Sclerotium, } \\
\text { Macrophomina, } \\
\text { Alternaria, } \\
\text { Helminthosporium, } \\
\text { Myrothecium, } \\
\text { Pilricularia, } \\
\text { Colletotrichum, } \\
\text { Cercospora, \& } \\
\text { Ramularia } \text { etc. }\end{array}$ & WP & $\mathrm{F}$ & ST & & & & \\
\hline Nicoderma & $\begin{array}{c}\text { Nico Orgo Manures. } \\
\text { Works } \\
\text { (http//www.neemnic } \\
\text { o.com/trichoderma. } \\
\text { htm) }\end{array}$ & India & T. viride & $\begin{array}{l}\text { Available } \\
\text { for use }\end{array}$ & $\begin{array}{l}\text { Control of soilborne } \\
\text { pathogens }\end{array}$ & & & $\mathrm{F}$ & & & & & \\
\hline
\end{tabular}


Appendix 1. contd...

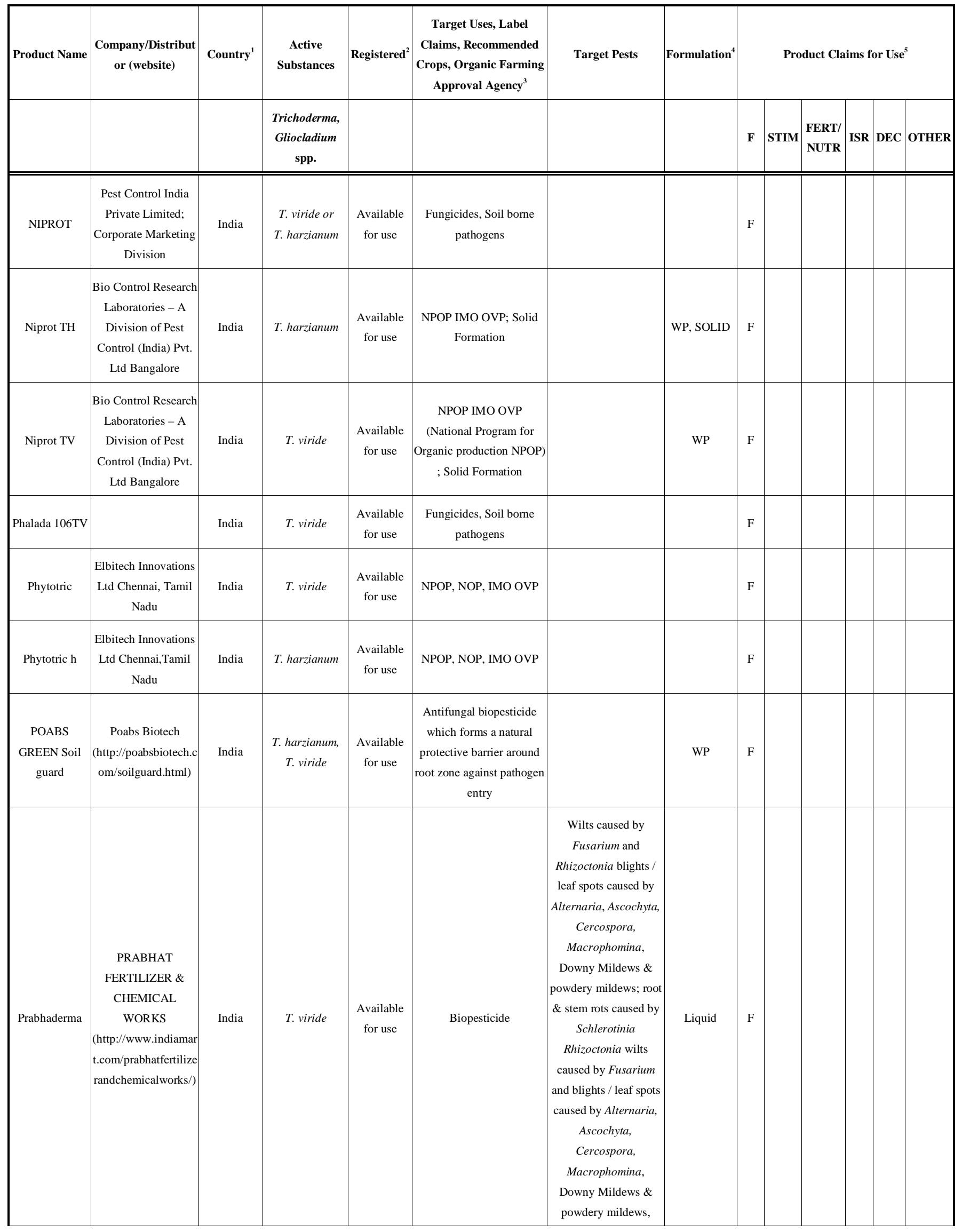


Appendix 1. contd...

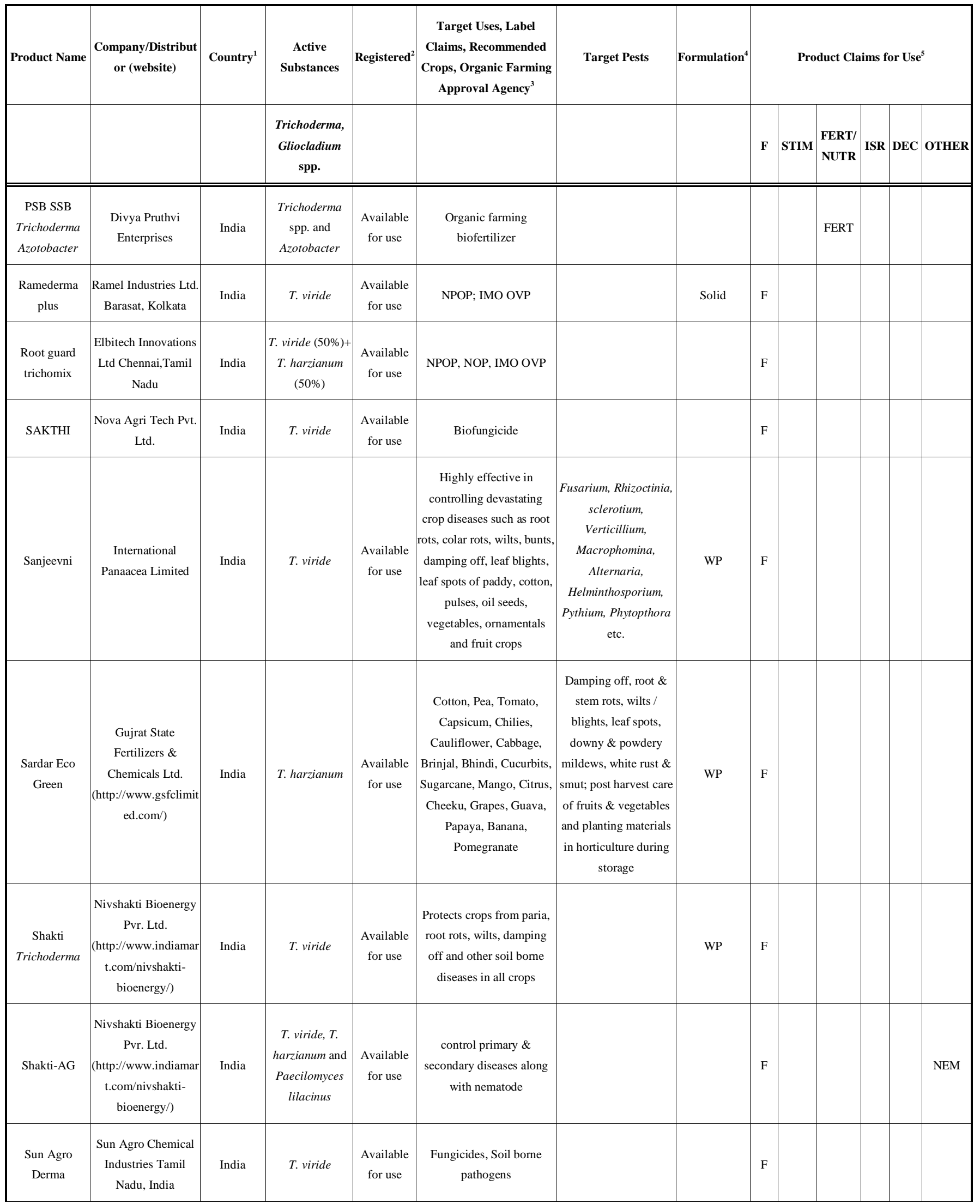


Appendix 1. contd...

\begin{tabular}{|c|c|c|c|c|c|c|c|c|c|c|c|c|c|}
\hline \multirow[t]{2}{*}{ Product Name } & \multirow{2}{*}{$\begin{array}{c}\text { Company/Distribut } \\
\text { or (website) }\end{array}$} & \multirow[t]{2}{*}{ Country $^{1}$} & \multirow{2}{*}{$\begin{array}{c}\text { Active } \\
\text { Substances } \\
\text { Trichoderma, } \\
\text { Gliocladium } \\
\text { spp. }\end{array}$} & \multirow[t]{2}{*}{ Registered $^{2}$} & \multirow{2}{*}{\begin{tabular}{|c|} 
Target Uses, Label \\
Claims, Recommended \\
Crops, Organic Farming \\
Approval Agency $^{3}$
\end{tabular}} & \multirow[t]{2}{*}{ Target Pests } & \multirow[t]{2}{*}{ Formulation $^{4}$} & \multicolumn{6}{|c|}{ Product Claims for Use ${ }^{5}$} \\
\hline & & & & & & & & $\mathbf{F}$ & STIM & $\begin{array}{l}\text { FERT/ } \\
\text { NUTR }\end{array}$ & ISR & DEC & OTHER \\
\hline $\begin{array}{c}\text { Sun Agro } \\
\text { Derma and Sun } \\
\text { Agro Derma - H }\end{array}$ & $\begin{array}{c}\text { Sun Agro Chemical } \\
\text { Industries Tamil } \\
\text { Nadu, India }\end{array}$ & India & $\begin{array}{l}\text { T. viride, } T \text {. } \\
\text { harzianum }\end{array}$ & $\begin{array}{l}\text { Available } \\
\text { for use }\end{array}$ & $\begin{array}{c}\text { Biopesticide controls wilts, } \\
\text { root \& stem rots, damping } \\
\text { off, several seed \& soil } \\
\text { borne disease and various } \\
\text { foliar diseases rice, } \\
\text { sugarcane, tobacco, } \\
\text { groundnut, soybean, } \\
\text { pepper, cardamom, } \\
\text { turmeric, ginger, coffee, } \\
\text { tea, rubber, vegetables and } \\
\text { fruit crops. }\end{array}$ & & WP & $\mathrm{F}$ & & & & & \\
\hline T. harzianum & $\begin{array}{l}\text { Bharat Biocon } \\
\text { Private Limited }\end{array}$ & India & T. harzianum & $\begin{array}{l}\text { Available } \\
\text { for use }\end{array}$ & $\begin{array}{c}\text { Biocontrol fungus that } \\
\text { protects the root system of } \\
\text { plant \& kills the target pest } \\
\text { effectively }\end{array}$ & & WP & $\mathrm{F}$ & & & & & \\
\hline T. viride & $\begin{array}{c}\text { East Coast Biotech } \\
\text { Project } \\
\text { (http://www.indiamar } \\
\text { t.com/eastcoast- } \\
\text { biotechproject/) }\end{array}$ & India & T. viride & $\begin{array}{l}\text { Available } \\
\text { for use }\end{array}$ & $\begin{array}{c}\text { Seed dressing; reduces } \\
\text { growth of pathogens quick } \\
\text { multiplication of disease } \\
\text { causing bacteria; tea, } \\
\text { coffee, tea, cereals, } \\
\text { coconut and cardamom }\end{array}$ & & & $\mathrm{F}$ & & & & & \\
\hline T. viride & $\begin{array}{c}\text { Govinda Agro Tech } \\
\text { Ltd } \\
\text { (http://www.indiamar } \\
\text { t.com/govinda- } \\
\text { agrotech/) }\end{array}$ & India & T. viride & $\begin{array}{l}\text { Available } \\
\text { for use }\end{array}$ & $\begin{array}{c}\text { Helps in preventing the } \\
\text { growth of pathogens } \\
\text { causing plant diseases like } \\
\text { root rot }\end{array}$ & & WP & $\mathrm{F}$ & & & & & \\
\hline T. viride & $\begin{array}{l}\text { Bharat Biocon } \\
\text { Private Limited }\end{array}$ & India & T. viride & $\begin{array}{l}\text { Available } \\
\text { for use }\end{array}$ & $\begin{array}{c}\text { Bio-fungicide, effective } \\
\text { against wide variety of } \\
\text { soil-borne plant pathogenic } \\
\text { fungi }\end{array}$ & & WP & $\mathrm{F}$ & & & & & \\
\hline T. viride & $\begin{array}{c}\text { ROCKY Imports and } \\
\text { Exports }\end{array}$ & India & T. viride & $\begin{array}{l}\text { Available } \\
\text { for use }\end{array}$ & $\begin{array}{c}\text { Biocontrol agent, } \\
\text { antagonistic fungus; crops } \\
\text { like sugar cane, oil seeds, } \\
\text { cotton, vegetables, Banana, } \\
\text { Coconut, Oil palm, } \\
\text { Chillies, Pulses etc. }\end{array}$ & & WP Seed trt & $\mathrm{F}$ & & & & & \\
\hline T. viride & Nandhini Bio Tech & India & T. viride & $\begin{array}{l}\text { Available } \\
\text { for use }\end{array}$ & $\begin{array}{c}\text { Seed and soil treatment for } \\
\text { suppression of various } \\
\text { diseases caused by fungal } \\
\text { pathogens }\end{array}$ & $\begin{array}{c}\text { seed dressing in the } \\
\text { control of seed and } \\
\text { soil-borne diseases } \\
\text { including Rhizoctonia } \\
\text { solani, macrophomina } \\
\text { phaseolina } \text { and } \\
\text { Fusarium species }\end{array}$ & & $\mathrm{F}$ & & & & & \\
\hline
\end{tabular}


Appendix 1. contd...

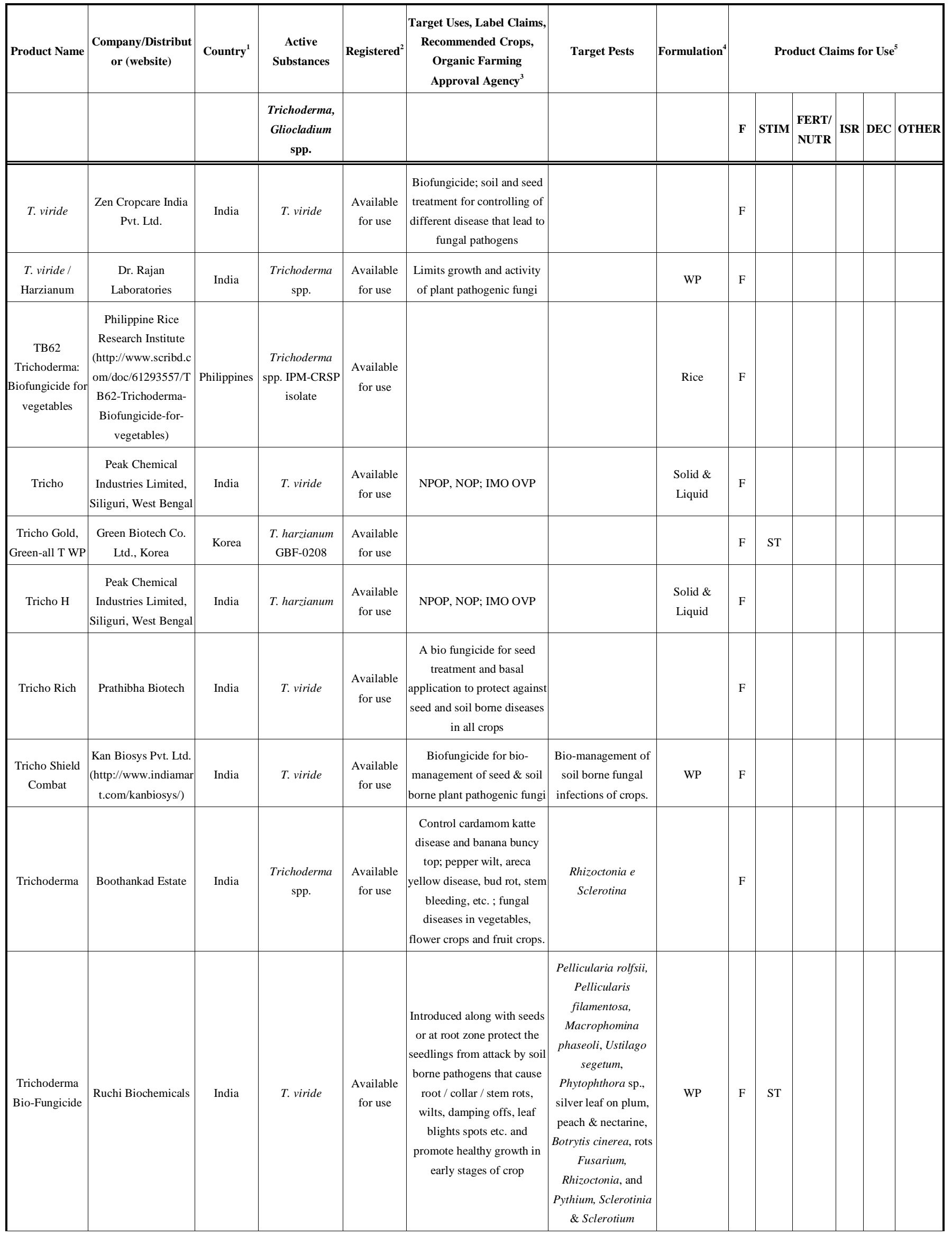


Appendix 1. contd...

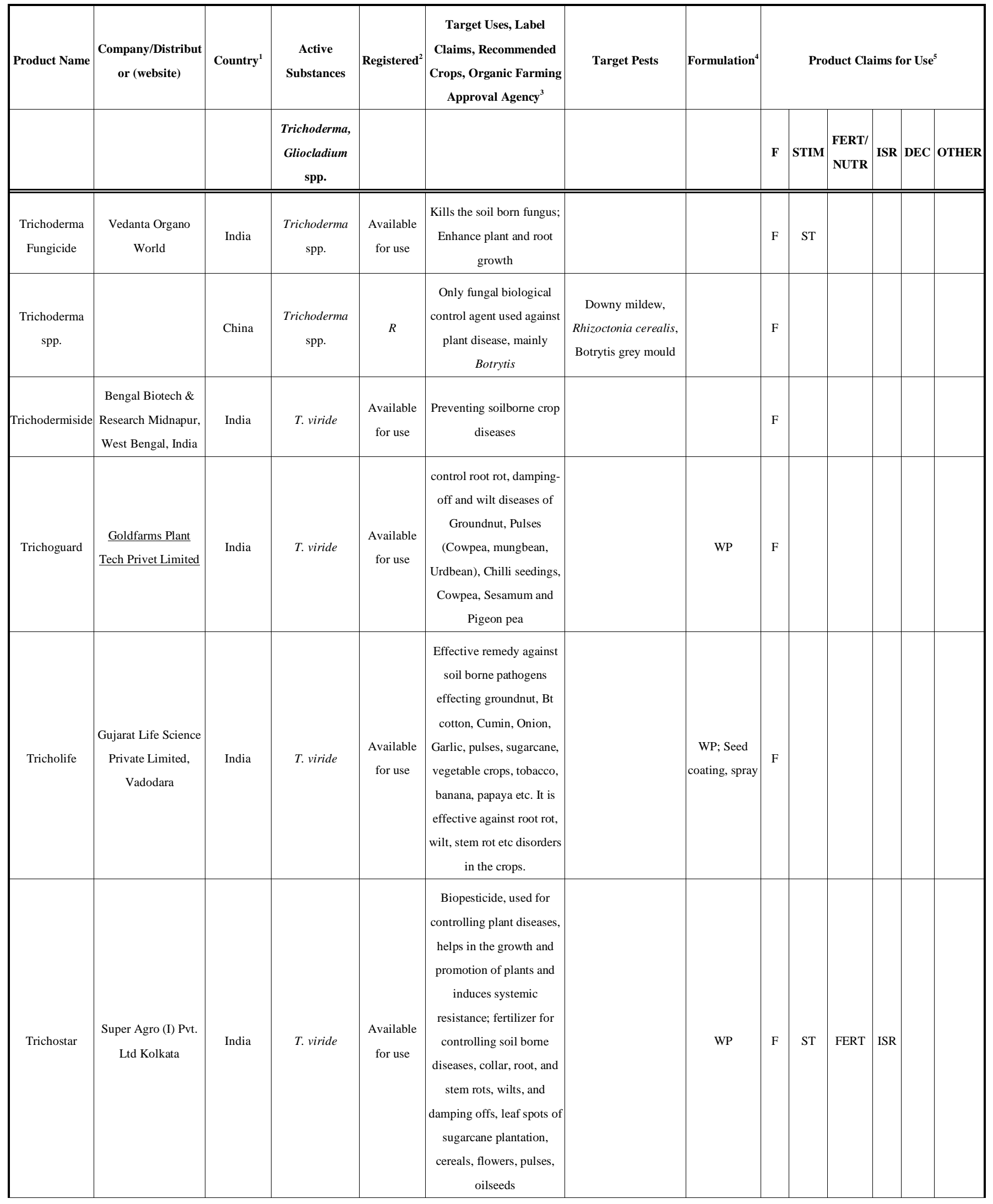


Appendix 1. contd...

\begin{tabular}{|c|c|c|c|c|c|c|c|c|c|c|c|c|c|}
\hline \multirow[t]{2}{*}{ Product Name } & \multirow[t]{2}{*}{$\begin{array}{c}\text { Company/Distribut } \\
\text { or (website) }\end{array}$} & \multirow[t]{2}{*}{ Country $^{1}$} & \multirow{2}{*}{\begin{tabular}{|c|} 
Active \\
Substances \\
$\begin{array}{c}\text { Trichoderma, } \\
\text { Gliocladium } \\
\text { spp. }\end{array}$ \\
\end{tabular}} & \multirow[t]{2}{*}{ Registered $^{2}$} & \multirow{2}{*}{\begin{tabular}{|c|} 
Target Uses, Label \\
Claims, Recommended \\
Crops, Organic Farming \\
Approval Agency $^{3}$
\end{tabular}} & \multirow[t]{2}{*}{ Target Pests } & \multirow[t]{2}{*}{ Formulation $^{4}$} & \multicolumn{6}{|c|}{ Product Claims for Use $^{5}$} \\
\hline & & & & & & & & $\mathbf{F}$ & STIM & $\begin{array}{l}\text { FERT/ } \\
\text { NUTR }\end{array}$ & ISR & DEC & OTHER \\
\hline Tricone $\mathrm{V}$ & Neuscire Biolab & India & $\begin{array}{l}\text { T. harzianum, } \\
\text { with neem }\end{array}$ & $\begin{array}{c}\text { Available } \\
\text { for use }\end{array}$ & $\begin{array}{c}\text { Plant growth promoter; } \\
\text { disease control, Quick wilt } \\
\text { of pepper, root rot of } \\
\text { memdrins rhizome rot of } \\
\text { ginger, capsule rot of } \\
\text { cardamom root rot of } \\
\text { ornamentals, damping off } \\
\text { and other nursery diseases, } \\
\text { nematodes in banana wilt } \\
\text { and mildew in vegetables }\end{array}$ & $\begin{array}{c}\text { All soil borne fungal } \\
\text { diseases, against } \\
\text { Pythium sp, ganaderma } \\
\text { sp, } \text { Rhizoctonia solani, } \\
\text { Fusarium sp; plant } \\
\text { parasitic nematodes. } \\
\text { Banana nematode - } \\
\text { radopholus similis, } \\
\text { citrus nematode } \\
\text { tylenchulus } \\
\text { semipenetrans and } \\
\text { reniform nematode } \\
\text { rotelenechulus } \\
\text { reniformis). }\end{array}$ & WP & $\mathrm{F}$ & ST & & & & \\
\hline Tricontrol & - & India & T. viride & $\begin{array}{c}\text { Available } \\
\text { for use }\end{array}$ & $\begin{array}{c}\text { Fungicides, Soil borne } \\
\text { pathogens }\end{array}$ & & & $\mathrm{F}$ & & & & & \\
\hline Trieco & $\begin{array}{c}\text { Ecosense Lab India } \\
\text { Private Limited }\end{array}$ & India & T. viride & $\begin{array}{c}\text { Available } \\
\text { for use }\end{array}$ & \begin{tabular}{|} 
Contributes to the \\
development of various \\
plant growth stimuli for \\
root and shoot elongation; \\
suppress root infesting \\
diseases
\end{tabular} & & $\begin{array}{c}\text { WP; seed trt, } \\
\text { propagation } \\
\text { material, soil } \\
\text { drench }\end{array}$ & $\mathrm{F}$ & ST & & & & \\
\hline Yash Derma & $\begin{array}{c}\text { Yash Krishi, Takniki } \\
\text { Ewam Vigyan } \\
\text { Kendra, Allahabad, } \\
\text { UP }\end{array}$ & India & T. viride & $\begin{array}{c}\text { Available } \\
\text { for use }\end{array}$ & NPOP, IMO OVP & & Solid & $\mathrm{F}$ & & & & & \\
\hline \multicolumn{14}{|c|}{ Europe (EU - 22 countries; others) } \\
\hline $\begin{array}{l}\text { Binab T P (in } \\
\text { development) }\end{array}$ & $\begin{array}{c}\text { Binab bio-innovation } \\
\text { eftr ab } \\
\text { (www.algonet.se/ bi } \\
\text { nab/index2.html ) }\end{array}$ & $\begin{array}{c}\text { EU (SE, } \\
\text { DN); Chile } \\
\text { (imported } \\
\text { by Agro- } \\
\text { Connexion); } \\
\text { USA } \\
\text { (cancelled) }\end{array}$ & $\mid \begin{array}{c}\text { T. atroviride IMI } \\
206040 \\
\text { (formerly } \\
\text { T.harzianum IMI } \\
206040 \text { ) }+T \text {. } \\
\text { polysporum } \text { IMI } \\
206039\end{array}$ & $\begin{array}{c}\text { R, Annex I } \\
(2008)\end{array}$ & Fruit trees & $\begin{array}{c}\text { Chondrostereum } \\
\text { purpureum; biocontrol } \\
\text { of Silver Leaf caused } \\
\text { by Chondrostereum } \\
\text { purpureum transmitted } \\
\text { by pruning wound } \\
\text { infection or root } \\
\text { contacts; pathogenic } \\
\text { fungi that cause wilt, } \\
\text { take-all, root rot, and } \\
\text { internal decay of wood } \\
\text { products and decay in } \\
\text { tree wounds }\end{array}$ & Pellets & $\mathrm{F}$ & & & & & \\
\hline Binab T Vector & $\begin{array}{c}\text { Binab bio-innovation } \\
\text { eftr ab } \\
\text { (www.algonet.se/ bi } \\
\text { nab/index2.html ) }\end{array}$ & $\begin{array}{l}\text { USA, EU } \\
\text { (SE, DN) }\end{array}$ & $\left|\begin{array}{c}\text { T. atroviride IMI } \\
206040 \\
\text { (formerly } \\
\text { T. harzianum IMI } \\
206040 \text { ) }\end{array}\right|$ & 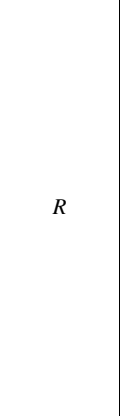 & $\begin{array}{c}\text { A powder for treating } \\
\text { flowers against fungal } \\
\text { pathogens through vector } \\
\text { transmission; Strawberries }\end{array}$ & \begin{tabular}{|} 
Botrytis cinerea, \\
controls fungal \\
pathogens such as \\
Botrytis, Verticillium, \\
Pythium, Fusarium, \\
Phytophthora, \\
Rhizoctonia, fairy rings \\
and other soil-borne \\
fungal pathogens, and \\
Didymella, \\
Chondrostereum and \\
Heterobasidion
\end{tabular} & $\begin{array}{c}\text { WP } \\
\text { (bumblebee } \\
\text { vectoring); }\end{array}$ & $\mathrm{F}$ & & & & & \\
\hline
\end{tabular}


Appendix 1. contd...

\begin{tabular}{|c|c|c|c|c|c|c|c|c|c|c|c|c|c|}
\hline \multirow[t]{2}{*}{ Product Name } & \multirow{2}{*}{$\begin{array}{c}\text { Company/Distribut } \\
\text { or (website) }\end{array}$} & \multirow[t]{2}{*}{ Country $^{1}$} & \multirow{2}{*}{\begin{tabular}{|c} 
Active \\
Substances \\
$\begin{array}{c}\text { Trichoderma, } \\
\text { Gliocladium } \\
\text { spp. }\end{array}$
\end{tabular}} & \multirow[t]{2}{*}{ Registered $^{2}$} & \multirow{2}{*}{\begin{tabular}{|c|} 
Target Uses, Label \\
Claims, Recommended \\
Crops, Organic Farming \\
Approval Agency $^{3}$
\end{tabular}} & \multirow[t]{2}{*}{ Target Pests } & \multirow[t]{2}{*}{ Formulation $^{4}$} & \multicolumn{6}{|c|}{ Product Claims for Use $^{5}$} \\
\hline & & & & & & & & $\mathbf{F}$ & STIM & $\begin{array}{l}\text { FERT/ } \\
\text { NUTR }\end{array}$ & ISR & DEC & OTHER \\
\hline Binab T WG & $\begin{array}{c}\text { Binab bio-innovation } \\
\text { eftr ab } \\
\text { (www.algonet.se/ bi } \\
\text { nab/index2.html ); } \\
\text { Biofa AG (Bio- } \\
\text { farming systems), } \\
\text { Rudolf-Diesel-Str. 2, } \\
\text { D-72525 } \\
\text { Münsingen, } \\
\text { Alemanha. }\end{array}$ & \begin{tabular}{|c} 
EU (SE, \\
DN, \\
Germany \\
(biofortifica \\
nt)
\end{tabular} & $\left|\begin{array}{c}\text { T. atroviride IMI } \\
206040 \\
\text { (formerly } \\
\text { T.harzianum IMI } \\
\text { 206040) }\end{array}\right|$ & $\begin{array}{c}\text { R, Annex I } \\
\text { (2008) }\end{array}$ & $\begin{array}{c}\text { Botrytis cinerea on } \\
\text { Strawberries }\end{array}$ & $\begin{array}{l}\text { Chondrostereum } \\
\text { purpureum on } \\
\text { Ornamental trees }\end{array}$ & WP (spray) & $\mathrm{F}$ & & & & & \\
\hline Binab TF WP & $\left|\begin{array}{c}\text { Binab bio-innovation } \\
\text { eftr ab } \\
\text { (www.algonet.se/ bi } \\
\text { nab/index } 2 . h t m l \text { ) }\end{array}\right|$ & $\begin{array}{c}\mathrm{R} \text { in EU } \\
\text { (SE, DN); } \\
\text { Chile } \\
\text { (imported } \\
\text { by Agro- } \\
\text { Connexion) }\end{array}$ & $\left|\begin{array}{c}\text { T. atroviride IMI } \\
206040 \\
\text { (formerly } \\
\text { T.harzianum IMI } \\
\text { 206040) }\end{array}\right|$ & $\begin{array}{c}\text { R, Annex I } \\
\text { (2008) }\end{array}$ & $\begin{array}{c}\text { Botrytis cinerea on } \\
\text { Strawberries }\end{array}$ & $\begin{array}{l}\text { Chondrostereum } \\
\text { purpureum on } \\
\text { Ornamental trees }\end{array}$ & WP (spray) & $\mathrm{F}$ & & & & & \\
\hline Biocure F & \begin{tabular}{|c|} 
T. Stanes and \\
Company Limited, \\
Coimbatore, \\
Tamilnadu; \\
http://www.tstanes.co \\
m/bio_cure_f. \\
html
\end{tabular} & $\begin{array}{c}\text { EU; } \\
\text { available } \\
\text { India }\end{array}$ & T. viride & $R$ & $\begin{array}{l}\text { Diverse crops; NPOP, } \\
\text { NOP; IMO OVP }\end{array}$ & $\begin{array}{c}\text { Pythium sp., } \\
\text { Rhizoctonia solani, } \\
\text { Fusarium spp., Botrytis } \\
\text { cinerea, Sclerotium } \\
\text { rolfsii, Sclerotinia } \\
\text { homoeocarpa e } \\
\text { Ustilago tritici }\end{array}$ & $\begin{array}{c}\text { WP, Solid \& } \\
\text { Liquid }\end{array}$ & $\mathrm{F}$ & & & & & \\
\hline Bionitrongen $\mathrm{G}$ & $\begin{array}{c}\text { Agrifutur } \\
\text { (http://www.agrifutur } \\
\text {.com/IT/c/bionitroge } \\
\text { n-g-39/ }\end{array}$ & Italy & \begin{tabular}{|} 
T. harzianum, \\
Glomus $\mathrm{e}$ \\
Bradyrhizobium \\
japonicum
\end{tabular} & $\begin{array}{c}\text { Available } \\
\text { for use }\end{array}$ & & & & $\mathrm{F}$ & & & & & \\
\hline BioPlantguard & Saipan SRL & Italy & \begin{tabular}{|c|} 
Trichoderma \\
spp., mycorhizze, \\
bacteria, \\
fermentation \\
products
\end{tabular} & $\begin{array}{l}\text { Available } \\
\text { for use }\end{array}$ & $\begin{array}{c}\text { Treatment of seeds, plants } \\
\text { and fruit to augment their } \\
\text { resistence to biotic and } \\
\text { abiotic stresses }\end{array}$ & $\begin{array}{c}\text { Antagonistic to } \\
\text { soilborne and foliar } \\
\text { pathogens: Fusarium, } \\
\text { Verticillium, } \\
\text { Sclerotinia, Botrite, } \\
\text { Pythium, Rhizoctonia }\end{array}$ & Liquid & $\mathrm{F}$ & ST & FERT & & & \\
\hline Bioten & Isagro Spa & Spain & $\begin{array}{c}\text { T. asperellum } \\
\text { ICC } 012+ \\
\text { T. gamsii ICC } \\
080\end{array}$ & $\begin{array}{c}\text { Availabe for } \\
\text { use }\end{array}$ & $\begin{array}{c}\text { Flowers, Ornamentals in } \\
\text { vase (Chrysanthemums, } \\
\text { cyclamens, poinsettia, } \\
\text { primula etc.); Horticulture } \\
\text { (tomato, peppers, salads } \\
\text { (lettuce, radicchio, indivia, } \\
\text { rucola), melon, fennel, } \\
\text { artichoke, basil, celery, } \\
\text { beans, zucchine, eggplant, } \\
\text { cucumber, aromatic herbs }\end{array}$ & $\begin{array}{c}\text { Rhizoctonia solani, } \\
\text { Sclerotinia } \\
\text { sclerotiorum, } \\
\text { Verticillium dahliae, } \\
\text { Thielaviopsis basicola, } \\
\text { Phytophthora capsici. }\end{array}$ & WP & $\mathrm{F}$ & & & & & \\
\hline
\end{tabular}


Appendix 1. contd...

\begin{tabular}{|c|c|c|c|c|c|c|c|c|c|c|c|c|c|}
\hline \multirow[t]{2}{*}{ Product Name } & \multirow[t]{2}{*}{$\begin{array}{c}\text { Company/Distribut } \\
\text { or (website) }\end{array}$} & \multirow[t]{2}{*}{ Country $^{1}$} & \multirow{2}{*}{$\begin{array}{c}\text { Active } \\
\text { Substances } \\
\begin{array}{c}\text { Trichoderma, } \\
\text { Gliocladium } \\
\text { spp. }\end{array}\end{array}$} & \multirow[t]{2}{*}{ Registered $^{2}$} & \multirow{2}{*}{$\begin{array}{c}\text { Target Uses, Label } \\
\text { Claims, Recommended } \\
\text { Crops, Organic Farming } \\
\text { Approval Agency }^{3}\end{array}$} & \multirow[t]{2}{*}{ Target Pests } & \multirow[t]{2}{*}{ Formulation $^{4}$} & \multicolumn{6}{|c|}{ Product Claims for Use ${ }^{5}$} \\
\hline & & & & & & & & $\mathbf{F}$ & STIM & $\begin{array}{l}\text { FERT/ } \\
\text { NUTR }\end{array}$ & ISR & DEC & OTHER \\
\hline $\begin{array}{l}\text { CANNA } \\
\text { AkTRivator }\end{array}$ & \begin{tabular}{|c|} 
CANNA \\
(http://www.canna- \\
uk.com/aktrivator)
\end{tabular} & UK & $\begin{array}{l}\text { Trichoderma } \\
\text { spp. }\end{array}$ & $\begin{array}{c}\text { Available } \\
\text { for use }\end{array}$ & $\begin{array}{c}\text { Stimulates the plants and } \\
\text { increases root } \\
\text { development, reduced } \\
\text { disease, }\end{array}$ & $\begin{array}{l}\text { It stimulates plant } \\
\text { growth. }\end{array}$ & WP, Granules & $\mathrm{F}$ & ST & & & & \\
\hline $\begin{array}{l}\text { CANNA Coco } \\
\text { (Slabs, } \\
\text { Professional } \\
\text { Plus, Natural) }\end{array}$ & \begin{tabular}{|c|} 
CANNA \\
(http://www.canna- \\
uk.com/aktrivator)
\end{tabular} & UK & $\begin{array}{l}\text { Trichoderma } \\
\text { spp. included }\end{array}$ & $\begin{array}{c}\text { Available } \\
\text { for use }\end{array}$ & $\begin{array}{c}\text { coco-based growing } \\
\text { medium contains a special } \\
\text { mould (Trichoderma) that } \\
\text { protects the plants against } \\
\text { soil diseases }\end{array}$ & $\begin{array}{c}\text { stimulates the plants } \\
\text { and increases root } \\
\text { development, reduced } \\
\text { disease, }\end{array}$ & solid (coco) & $\mathrm{F}$ & ST & & & & \\
\hline Compete Plus & \begin{tabular}{|c|} 
Plant Health Care \\
(http://www.planthea \\
lthcare.com)
\end{tabular} & Spain, USA & \begin{tabular}{|c} 
T. harzianum + \\
Bacillus $(6 \mathrm{spp})$. \\
+ Streptomyses
\end{tabular} \mid & $\begin{array}{c}\text { Available } \\
\text { for use }\end{array}$ & $\begin{array}{l}\text { Soil inoculant, root } \\
\text { promotions }\end{array}$ & & WP & $\mathrm{F}$ & ST & & & & \\
\hline Condor & $\begin{array}{c}\text { Italpollina } \\
\text { (http://www.italpolli } \\
\text { na.com/Product/36/T } \\
\text { IFI) }\end{array}$ & uk & $\begin{array}{c}\text { T. atroviride } \\
898 \mathrm{G}+\text { Glomus } \\
\text { spp.+ Bacteria }\end{array}$ & $\begin{array}{l}\text { Available } \\
\text { for use, }\end{array}$ & $\begin{array}{c}\text { Horticulture, orchards and } \\
\text { trees. Direct action on } \\
\text { many pathogenic fungi, } \\
\text { stimulates plant growth, } \\
\text { protects leaves and fruits } \\
\text { against attacks by Botrytis } \\
\text { spp. and Phytophthora spp. }\end{array}$ & $\begin{array}{l}\text { It protects the plants' } \\
\text { roots in soils } \\
\text { contaminated with } \\
\text { pathogenic fungi. }\end{array}$ & & $\mathrm{F}$ & ST & & & & \\
\hline Eco-T & \begin{tabular}{|} 
Plant Health Products \\
(Pty)Ltd - \\
http://www.plant- \\
health.co.za/
\end{tabular} & $\begin{array}{l}\text { R South } \\
\text { Africa, } \\
\text { Kenya, } \\
\text { Zambia, FR, } \\
\text { UK, } \\
\text { Morocco, } \\
\text { Tunisia, } \\
\text { India }\end{array}$ & $\begin{array}{l}\text { T. harzianum } \\
\text { strain kd }\end{array}$ & $R$ & $\begin{array}{c}\text { Control of crop root } \\
\text { diseases and for enhanced } \\
\text { plant growth }\end{array}$ & $\begin{array}{c}\text { Rhizoctonia, Pythium, } \\
\text { Fusariume } \\
\text { Phytophthora }\end{array}$ & $\begin{array}{c}\text { WP, seed trt, } \\
\text { irrigation }\end{array}$ & $\mathrm{F}$ & ST & & & & \\
\hline Esquive WP & $\begin{array}{c}\text { Agrauxine, ZA de } \\
\text { Troyalac'h } \\
\text { (http://www.agrauxin } \\
\text { e.com/) }\end{array}$ & $\begin{array}{c}\text { Europe } \\
\text { (France), } \\
\text { Australia, } \\
\text { New } \\
\text { Zealand, } \\
\text { South } \\
\text { Africa, } \\
\text { Vietnam }\end{array}$ & $\begin{array}{l}\text { T. atroviride } \\
1237\end{array}$ & $\begin{array}{c}\text { R, Annex I } \\
(2012)\end{array}$ & $\begin{array}{c}\text { Vineyards, nursery, Grapes } \\
\text { - root, dieback }\end{array}$ & $\begin{array}{c}\text { Eutypa, Botryosphaeria } \\
\text { spp., Phaeomoniella, } \\
\text { Phaeoacremonium }\end{array}$ & $\begin{array}{l}\text { WP, pruning, } \\
\text { dip, aerial } \\
\text { spray }\end{array}$ & $\mathrm{F}$ & & & & & \\
\hline Fungistop & $\begin{array}{c}\text { Nyva/Bionaservice } \\
\text { Ltd. }\end{array}$ & $\begin{array}{l}\text { Ukraine, } \\
\text { Certified } \\
\text { according to } \\
\text { EU , NOP } \\
05 / 04 / 12- \\
05 / 07 / 13\end{array}$ & T. viride & $\begin{array}{c}\text { Available } \\
\text { for use }\end{array}$ & $\begin{array}{c}\text { Control of fungal diseases } \\
\text { in greenhouses }\end{array}$ & & & $\mathrm{F}$ & & & & & \\
\hline GlioMix & \begin{tabular}{|c|} 
Verdera Oy ( \\
Formerly Kemira \\
Agro Oy), \\
http://www.verdera.fi \\
/homeeng.html
\end{tabular} & $\begin{array}{l}\text { USA; } \\
\text { Finland, } \\
\text { Germany }\end{array}$ & Gliocladium spp. & $R$ & $\begin{array}{c}\text { Prevention and control of } \\
\text { soilborne pathogens; } \\
\text { ornamentals and diverse } \\
\text { crops }\end{array}$ & & $\begin{array}{l}\text { WP (soil, } \\
\text { substrate) }\end{array}$ & $\mathrm{F}$ & & & & & \\
\hline
\end{tabular}


Appendix 1. contd...

\begin{tabular}{|c|c|c|c|c|c|c|c|c|c|c|c|c|c|}
\hline \multirow[t]{2}{*}{ Product Name } & \multirow{2}{*}{$\begin{array}{c}\text { Company/Distribut } \\
\text { or (website) }\end{array}$} & \multirow[t]{2}{*}{ Country $^{1}$} & \multirow{2}{*}{\begin{tabular}{c|} 
Active \\
Substances \\
Trichoderma, \\
Gliocladium \\
spp.
\end{tabular}} & \multirow[t]{2}{*}{ Registered $^{2}$} & \multirow{2}{*}{$\begin{array}{c}\text { Target Uses, Label } \\
\text { Claims, Recommended } \\
\text { Crops, Organic Farming } \\
\text { Approval Agency }^{3}\end{array}$} & \multirow[t]{2}{*}{ Target Pests } & \multirow[t]{2}{*}{ Formulation $^{4}$} & \multicolumn{6}{|c|}{ Product Claims for Use ${ }^{5}$} \\
\hline & & & & & & & & $\mathbf{F}$ & STIM & $\begin{array}{l}\text { FERT/ } \\
\text { NUTR }\end{array}$ & ISR & DEC & OTHER \\
\hline $\begin{array}{l}\text { Great White } \\
\text { Premium } \\
\text { Mycorrhize }\end{array}$ & $\begin{array}{l}\text { Plant Success } \\
\text { (www.plant- } \\
\text { success.com) }\end{array}$ & UK & $\begin{array}{c}\text { T. koningii, } T \text {. } \\
\text { harzianum, } \\
\text { mycorrhize } \\
\text { fungi (15 spp.), } \\
\text { bacteria (11 } \\
\text { spp.) }\end{array}$ & $\begin{array}{l}\text { Available } \\
\text { for use }\end{array}$ & $\begin{array}{c}\text { Plant and root growth } \\
\text { promoter }\end{array}$ & & $\begin{array}{l}\text { WP, seeds, } \\
\text { cuttings, } \\
\text { transplants, } \\
\text { hydroponics }\end{array}$ & & ST & & & & \\
\hline $\begin{array}{c}\text { GROW BOOST } \\
\text { Plant } \\
\text { Strengthener }\end{array}$ & $\begin{array}{c}\text { dragonfli } \\
\text { (http://www.dragonfl } \\
\text { i.co.uk) }\end{array}$ & UK & $\begin{array}{c}\text { T. harzianum } \mathrm{T}- \\
22\end{array}$ & $\begin{array}{l}\text { Available } \\
\text { for use }\end{array}$ & $\begin{array}{c}\text { Wide range of plants } \\
\text { including vegetables and } \\
\text { salads, vegetables of the } \\
\text { brassica family }\end{array}$ & $\begin{array}{c}\text { Healthier and stronger } \\
\text { plants, Suppression of } \\
\text { soil borne diseases, } \\
\text { Greater survival rates } \\
\text { of transplants, } \\
\text { seedlings and young } \\
\text { plants }\end{array}$ & WP - sachet & $\mathrm{F}$ & & & & & \\
\hline Lycomax & $\begin{array}{c}\text { Russelli PM } \\
\text { (http://www.russellip } \\
\text { m.com) }\end{array}$ & UK & T. harzianum & $\begin{array}{l}\text { Available } \\
\text { for use }\end{array}$ & $\begin{array}{l}\text { Soilborne pathogens; } \\
\text { potatoes, root crops, } \\
\text { ornamentals }\end{array}$ & & Granules & $\mathrm{F}$ & & & & & \\
\hline $\begin{array}{c}\text { Micover Gold e } \\
\text { Plus }\end{array}$ & $\begin{array}{c}\text { Agrifutur } \\
\text { (http://www.agrifutur } \\
\text {.com/) }\end{array}$ & EU & $\begin{array}{l}\text { T. harzianum, } \\
\text { Glomus } \\
\text { intraradices e } \\
\text { Pseudomonas }\end{array}$ & $\mathrm{R}$ & Soilborne pathogens & & Granules & $\mathrm{F}$ & & & & & \\
\hline $\begin{array}{l}\text { Mycofungicyd } \\
\text { (Trichodermin) }\end{array}$ & & Ukraine & T. viride & $\mathrm{R}$ & & $\begin{array}{l}\text { Root rots, white rot, } \\
\text { fusariosis, verticillosis }\end{array}$ & & $\mathrm{F}$ & & & & & \\
\hline $\begin{array}{c}\text { Micosat } F \text {, } \\
\text { Micosat } F \text { (for } \\
\text { organic } \\
\text { farming) }\end{array}$ & C.C.S Aosta s.r.l. & Italy & \begin{tabular}{|} 
T. harzianum \\
TH01, +spp. of \\
Glomus (3), \\
Agrobacterium, \\
Bacillus, \\
Streptomyces, \\
Beauveria, \\
Pichia
\end{tabular} & $\begin{array}{l}\text { Available } \\
\text { for use }\end{array}$ & $\begin{array}{l}\text { All granular formulations } \\
\text { increment root } \\
\text { development and } \\
\text { protection from soilborne } \\
\text { diseases }\end{array}$ & & $\begin{array}{l}\text { Granules, } \\
\text { manuale or } \\
\text { mechanical } \\
\quad \text { soil } \\
\text { distribution }\end{array}$ & $\mathrm{F}$ & ST & & & & \\
\hline $\begin{array}{c}\text { Micosat F } \\
\text { cereali, Micosat } \\
\text { F cereali (for } \\
\text { org. farm.) }\end{array}$ & C.C.S Aosta s.r.l. & Italy & $\begin{array}{c}\text { T. atroviride TA } \\
28, \text { T. harzianum } \\
\text { TH01, +spp. of } \\
\text { Glomus (3), } \\
\text { Bacillus, } \\
\text { Beauveria }\end{array}$ & $\begin{array}{c}\text { Available } \\
\text { for use }\end{array}$ & $\begin{array}{l}\text { All granular formulations } \\
\text { increment root } \\
\text { development and } \\
\text { protection from soilborne } \\
\text { diseases }\end{array}$ & & $\begin{array}{l}\text { Granules, } \\
\text { manuale or } \\
\text { mechanical } \\
\quad \text { soil } \\
\text { distribution }\end{array}$ & $\mathrm{F}$ & ST & & & & \\
\hline $\begin{array}{c}\text { Micosat } F \\
\text { patata, Micosat } \\
\text { F patata (for } \\
\text { org. farm.) }\end{array}$ & C.C.S Aostas.r.l. & Italy & \begin{tabular}{|} 
T. atroviride TA \\
$28,+$ spp. of \\
Glomus (3), \\
Agrobacterium, \\
Bacillus, \\
Streptomyces, \\
Beauveria, \\
Pochonia
\end{tabular} & $\begin{array}{l}\text { Available } \\
\text { for use }\end{array}$ & $\begin{array}{l}\text { All granular formulations } \\
\text { increment root } \\
\text { development and } \\
\text { protection from soilborne } \\
\text { diseases }\end{array}$ & & $\begin{array}{l}\text { Granules, } \\
\text { manuale or } \\
\text { mechanical } \\
\quad \text { soil } \\
\text { distribution }\end{array}$ & $\mathrm{F}$ & ST & & & & \\
\hline
\end{tabular}


Appendix 1. contd...

\begin{tabular}{|c|c|c|c|c|c|c|c|c|c|c|c|c|c|}
\hline \multirow[t]{2}{*}{ Product Name } & \multirow[t]{2}{*}{$\begin{array}{c}\text { Company/Distribut } \\
\text { or (website) }\end{array}$} & \multirow[t]{2}{*}{ Country $^{1}$} & \multirow{2}{*}{\begin{tabular}{|c|} 
Active \\
Substances \\
$\begin{array}{c}\text { Trichoderma, } \\
\text { Gliocladium } \\
\text { spp. }\end{array}$ \\
\end{tabular}} & \multirow[t]{2}{*}{ Registered $^{2}$} & \multirow{2}{*}{$\begin{array}{c}\text { Target Uses, Label } \\
\text { Claims, Recommended } \\
\text { Crops, Organic Farming } \\
\text { Approval Agency }^{3}\end{array}$} & \multirow[t]{2}{*}{ Target Pests } & \multirow[t]{2}{*}{ Formulation } & \multicolumn{6}{|c|}{ Product Claims for Use ${ }^{5}$} \\
\hline & & & & & & & & $\mathbf{F}$ & STIM & FERT/ & ISR & DEC & OTHER \\
\hline $\begin{array}{l}\text { Micosat } F \text { vite, } \\
\text { Micosat } F \text { vite } \\
\text { (for org. farm.); } \\
\text { Micosat } F \text { olivo } \\
\text { Micosat } F \text { olivo } \\
\text { (for org. farm.) }\end{array}$ & C.C.S Aosta s.r.l. & Italy & $\begin{array}{c}\text { T. viride TV } 03, \\
\text { T. harzianum } \\
\text { TH01, +spp. of } \\
\text { Glomus (3), } \\
\text { Agrobacterium, } \\
\text { Bacillus, } \\
\text { Streptomyces, } \\
\text { Pichia }\end{array}$ & $\begin{array}{l}\text { Available } \\
\text { for use }\end{array}$ & $\begin{array}{c}\text { All granular formulations } \\
\text { increment root } \\
\text { development and } \\
\text { protection from soilborne } \\
\text { diseases }\end{array}$ & & $\begin{array}{c}\text { Granules, } \\
\text { manuale or } \\
\text { mechanical } \\
\text { soil } \\
\text { distribution }\end{array}$ & $\mathrm{F}$ & ST & & & & \\
\hline $\begin{array}{l}\text { Micosat F TAB } \\
\text { PLUS WP, } \\
\text { Micosat F TAB } \\
\text { PLUS WP (for } \\
\text { org. farm.) }\end{array}$ & C.C.S Aostas.r.l. & Italy & $\begin{array}{c}\text { T. harzianum } \\
\text { TH01, +spp. of } \\
\text { Glomus (5; } 8 \\
\text { isolates), } \\
\text { Agrobacterium, } \\
\text { Bacillus, } \\
\text { Streptomyces, } \\
\text { Beauveria, } \\
\text { Pichia }\end{array}$ & $\begin{array}{l}\text { Available } \\
\text { for use }\end{array}$ & \begin{tabular}{|} 
WP formulations induce \\
resistance to bacteria, \\
soilborne fungi, pathogens, \\
insects and nematodes \\
(depending on the \\
formulation)
\end{tabular} & & $\begin{array}{l}\text { WP, foliar } \\
\text { spray }\end{array}$ & $\mathrm{F}$ & & & ISR & & \\
\hline $\begin{array}{c}\text { Micosat F PO } \\
\text { WP, Micosat F } \\
\text { PO WP (for org } \\
\text { farm.) }\end{array}$ & C.C.S Aosta s.r.l. & Italy & $\begin{array}{c}\text { T. harzianum } \\
\text { TH01, T. viride } \\
\text { TV } 03,+ \text { spp. of } \\
\text { Glomus (5; } 8 \\
\text { isolates), } \\
\text { Bacillus, } \\
\text { Streptomyces, } \\
\text { Pichia }\end{array}$ & $\begin{array}{l}\text { Available } \\
\text { for use }\end{array}$ & \begin{tabular}{|} 
WP formulations induce \\
resistance to bacteria, \\
soilborne fungi, pathogens, \\
insects and nematodes \\
(depending on the \\
formulation)
\end{tabular} & & $\begin{array}{l}\text { WP, foliar } \\
\text { spray }\end{array}$ & $\mathrm{F}$ & & & ISR & & \\
\hline $\begin{array}{c}\text { Micosat F TAB } \\
\text { WP, Micosat F } \\
\text { TAB WP (for } \\
\text { org. farm.) }\end{array}$ & C.C.S Aosta s.r.l. & Italy & $\begin{array}{c}\text { T. harzianum } \\
\text { TH01, T. viride } \\
\text { TV 03, +spp. of } \\
\text { Glomus (5; } 8 \\
\text { isolates), } \\
\text { Bacillus, Pichia }\end{array}$ & $\begin{array}{c}\text { Available } \\
\text { for use }\end{array}$ & \begin{tabular}{|} 
WP formulations induce \\
resistance to bacteria, \\
soilborne fungi, pathogens, \\
insects and nematodes \\
(depending on the \\
formulation)
\end{tabular} & & $\begin{array}{l}\text { WP, foliar } \\
\text { spray }\end{array}$ & $\mathrm{F}$ & & & ISR & & \\
\hline
\end{tabular}


Appendix 1. contd...

\begin{tabular}{|c|c|c|c|c|c|c|c|c|c|c|c|c|c|}
\hline \multirow[t]{2}{*}{ Product Name } & \multirow{2}{*}{$\begin{array}{c}\text { Company/Distribut } \\
\text { or (website) }\end{array}$} & \multirow[t]{2}{*}{ Country $^{1}$} & \multirow{2}{*}{\begin{tabular}{|c} 
Active \\
Substances \\
$\begin{array}{c}\text { Trichoderma, } \\
\text { Gliocladium } \\
\text { spp. }\end{array}$
\end{tabular}} & \multirow[t]{2}{*}{ Registered $^{2}$} & \multirow{2}{*}{$\begin{array}{c}\text { Target Uses, Label } \\
\text { Claims, Recommended } \\
\text { Crops, Organic Farming } \\
\text { Approval Agency }^{3}\end{array}$} & \multirow[t]{2}{*}{ Target Pests } & \multirow[t]{2}{*}{ Formulation $^{4}$} & \multicolumn{6}{|c|}{ Product Claims for Use } \\
\hline & & & & & & & & $\mathbf{F}$ & STIM & $\begin{array}{l}\text { FERT/ } \\
\text { NUTR }\end{array}$ & ISR & DEC & OTHER \\
\hline Micosat Ffito & C.C.S Aostas.r.l. & Italy & \begin{tabular}{|} 
T. harzianum \\
TH01, +spp. of \\
Glomus (5; 8 \\
isolates), \\
Pseudomonas \\
(2), Pichia
\end{tabular} & $\begin{array}{c}\text { Available } \\
\text { for use }\end{array}$ & $\begin{array}{l}\text { WP formulations induce } \\
\text { resistance to bacteria, } \\
\text { soilborne fungi, pathogens, } \\
\text { insects and nematodes } \\
\text { (depending on the } \\
\text { formulation) }\end{array}$ & & $\begin{array}{l}\text { WP, foliar } \\
\text { spray }\end{array}$ & $\mathrm{F}$ & & & ISR & & \\
\hline $\begin{array}{l}\text { Micosat F semi } \\
\text { WP, Micosat F } \\
\text { semi WP (for } \\
\text { org. farm.) }\end{array}$ & C.C.S Aostas.r.l. & Italy & $\begin{array}{l}\text { T. harzianum } \\
\text { TH01, } T . \\
\text { atroviride TA } \\
28,+ \text { spp. of } \\
\text { Glomus (5; } 8 \\
\text { isolates), } \\
\text { Bacillus, } \\
\text { Beauveria }\end{array}$ & $\begin{array}{l}\text { Available } \\
\text { for use }\end{array}$ & $\begin{array}{l}\text { Powder formulations for } \\
\text { seed treatments increase } \\
\text { root development and } \\
\text { protection to soilborne } \\
\text { diseases }\end{array}$ & & $\begin{array}{l}\text { Powder, dry } \\
\text { seed treatment }\end{array}$ & $\mathrm{F}$ & ST & & & & \\
\hline $\begin{array}{c}\text { Micosat F } \\
\text { grano, Micosat } \\
\text { F grano (for org. } \\
\text { farm.) }\end{array}$ & C.C.S Aosta s.r.l. & Italy & $\begin{array}{l}\text { T. harzianum } \\
\text { TH01, } T \text {. } \\
\text { atroviride TA } \\
28,+ \text { spp. of } \\
\text { Glomus }(5 ; 8 \\
\text { isolates), } \\
\text { Bacillus, } \\
\text { Streptomyces, } \\
\text { Pichia }\end{array}$ & $\begin{array}{l}\text { Available } \\
\text { for use }\end{array}$ & $\begin{array}{c}\text { Powder formulations for } \\
\text { seed treatments increase } \\
\text { root development and } \\
\text { protection to soilborne } \\
\text { diseases }\end{array}$ & & $\begin{array}{l}\text { Powder, dry } \\
\text { seed treatment }\end{array}$ & $\mathrm{F}$ & ST & & & & \\
\hline $\begin{array}{c}\text { Plagron Coco } \\
\text { Substrate }\end{array}$ & $\begin{array}{c}\text { Plagron - } \\
\text { http://www.plagron.c } \\
\text { o.uk/mediums/plagro } \\
\text { n-coco-substrate-coir }\end{array}$ & UK & $\begin{array}{l}\text { Trichoderma } \\
\text { spp. Included }\end{array}$ & $\begin{array}{l}\text { Available } \\
\text { for use }\end{array}$ & & $\begin{array}{l}\text { protection against } \\
\text { malicious fungi }\end{array}$ & Solid coco & $\mathrm{F}$ & & & & & \\
\hline $\begin{array}{c}\text { PLANT } \\
\text { BOOST plant } \\
\text { strengthener }\end{array}$ & $\begin{array}{c}\text { dragonfli } \\
\text { (http://www.dragonfl } \\
\text { i.co.uk/product/ps- } \\
\text { 02) }\end{array}$ & UK & $\begin{array}{l}\text { T. harzianum T- } \\
22\end{array}$ & $\begin{array}{l}\text { Available } \\
\text { for use }\end{array}$ & $\begin{array}{c}\text { Increased plant root } \\
\text { development, Suppression } \\
\text { of soil borne diseases, } \\
\text { Increased yield for } \\
\text { vegetables and fruits, } \\
\text { Improved establishment of } \\
\text { plants after planting. wide } \\
\text { range of plants including } \\
\text { vegetables and salads }\end{array}$ & $\begin{array}{c}\text { Natural protection from } \\
\text { soil borne diseases } \\
\text { such as Pythium, } \\
\text { Fusarium, Rhizoctonia } \\
\text { and Sclerotinia }\end{array}$ & Granules & $\mathrm{F}$ & ST & & & & \\
\hline Promot WP & $\begin{array}{c}\text { Biofa AG (Bio- } \\
\text { farming systems) - } \\
\text { http://www.biofa- } \\
\text { farming.de }\end{array}$ & $\begin{array}{c}\mathrm{R} \text { in } \\
\text { Germany; } \\
\text { Kenya } \\
\text { (temp. 2010) }\end{array}$ & $\begin{array}{c}\text { T. harzianum, } T . \\
\text { koningii }\end{array}$ & $R$ & $\begin{array}{l}\text { horticultural and } \\
\text { ornamental crops }\end{array}$ & $\begin{array}{c}\text { Control of damping-off } \\
\text { and root rot caused by } \\
\text { Pythium }\end{array}$ & WP & $\mathrm{F}$ & & & & & \\
\hline Radix & Isagro Spa & Italy & $\begin{array}{c}\text { T. asperellum } \\
\text { ICC } 012+ \\
\text { T. gamsii ICC } \\
080\end{array}$ & $\begin{array}{c}\text { Availabe for } \\
\text { use }\end{array}$ & & & WP & $\mathrm{F}$ & & & & & \\
\hline
\end{tabular}


Appendix 1. contd...

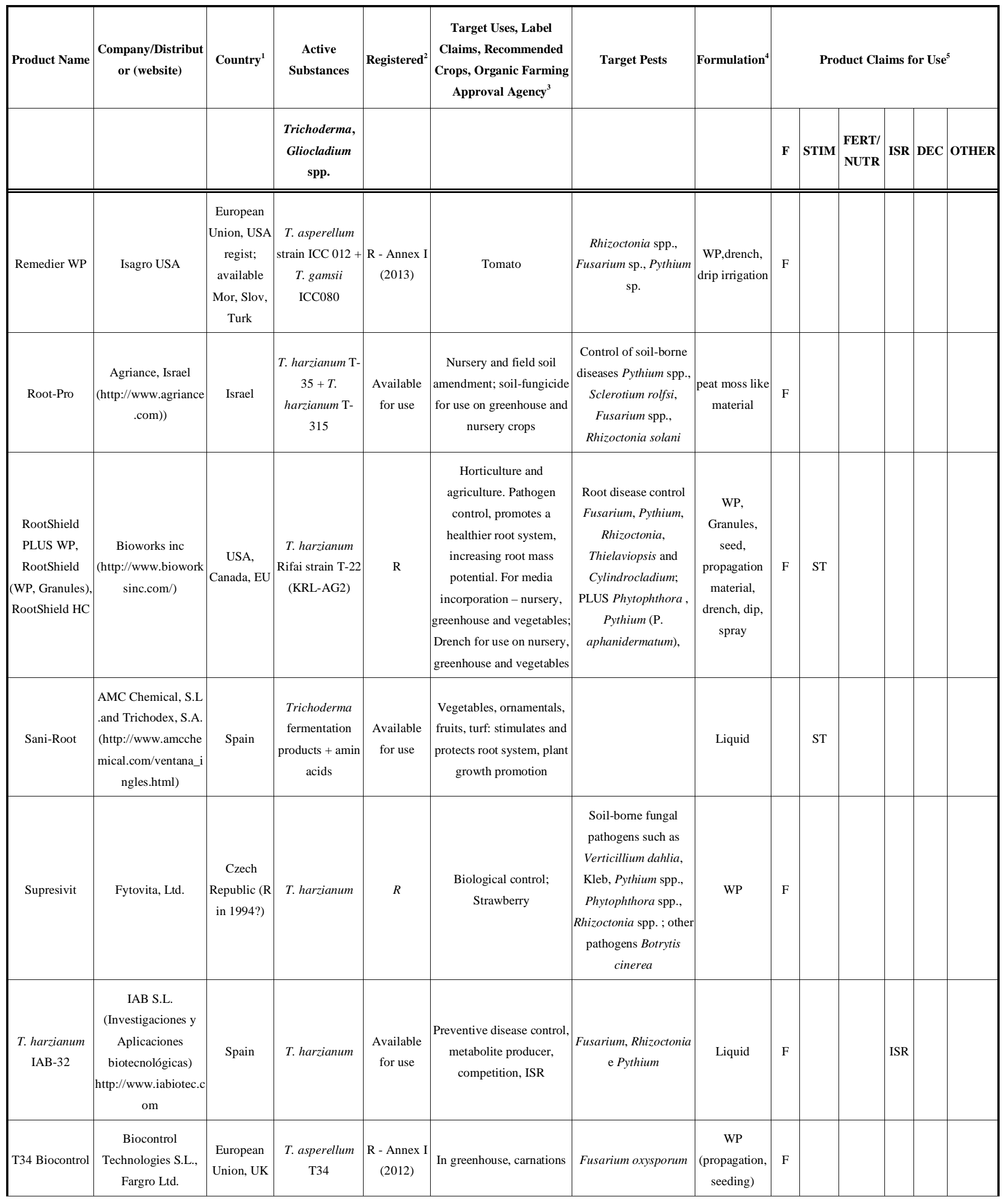


Appendix 1. contd...

\begin{tabular}{|c|c|c|c|c|c|c|c|c|c|c|c|c|c|}
\hline \multirow[t]{2}{*}{ Product Name } & \multirow{2}{*}{$\begin{array}{c}\text { Company/Distribut } \\
\text { or (website) }\end{array}$} & \multirow[t]{2}{*}{ Country ${ }^{1}$} & \multirow{2}{*}{$\begin{array}{c}\text { Active } \\
\text { Substances } \\
\begin{array}{c}\text { Trichoderma, } \\
\text { Gliocladium } \\
\text { spp. }\end{array}\end{array}$} & \multirow[t]{2}{*}{ Registered $^{2}$} & \multirow{2}{*}{$\begin{array}{c}\text { Target Uses, Label } \\
\text { Claims, Recommended } \\
\text { Crops, Organic Farming } \\
\text { Approval Agency }^{3}\end{array}$} & \multirow[t]{2}{*}{ Target Pests } & \multirow[t]{2}{*}{ Formulation $^{4}$} & \multicolumn{6}{|c|}{ Product Claims for Use $^{5}$} \\
\hline & & & & & & & & $\mathbf{F}$ & STIM & $\begin{array}{l}\text { FERT/ } \\
\text { NUTR }\end{array}$ & ISR & DEC & OTHER \\
\hline TIFI & $\begin{array}{c}\text { Italpollina } \\
\text { (http://www.italpolli } \\
\text { na.com/Product/36/T } \\
\text { IFI) }\end{array}$ & fr, it, es & $\begin{array}{c}\text { T. atroviride } \\
898 \mathrm{G}+\text { Glomus } \\
\text { spp.+Bacteria }\end{array}$ & $\begin{array}{l}\text { Available } \\
\text { for use }\end{array}$ & \begin{tabular}{|} 
Seeds, nursery, vegetables \\
(field and greenhose), \\
trees, ornamentals, grass. \\
Direct action on many \\
pathogenic fungi. A \\
fertilizer allowed in \\
organic farming according \\
to Italian Decreto
\end{tabular} & $\begin{array}{c}\text { Soils (Fusarium spp., } \\
\text { Rhizoctonia } \text { spp., } \\
\text { Verticillium } \text { spp., } \\
\text { Armillaria } \text { spp.) and } \\
\text { plants (Phytophtora } \\
\text { spp., Botrytis spp. } \\
\text { ecc.). }\end{array}$ & & $\mathrm{F}$ & & FERT & & & \\
\hline $\begin{array}{l}\text { TNC Mycorr } \\
\text { (Max, Hydro) }\end{array}$ & \begin{tabular}{|} 
The Nutrient \\
Company - \\
www.thenutrientcom \\
pany.com/
\end{tabular} & UK & \begin{tabular}{|} 
Trichoderma \\
spp. (5) + \\
mycorrhize (15 \\
spp.) + Bacillus \\
spp. (13)
\end{tabular} & $\begin{array}{c}\text { Availabe for } \\
\text { use }\end{array}$ & $\begin{array}{c}\text { Biostimulant, increased } \\
\text { nutrient uptake, drought } \\
\text { tolerance, pathogen } \\
\text { resistance }\end{array}$ & $\begin{array}{c}\text { Unique strain for great } \\
\text { adaptability to soils and } \\
\text { environmental } \\
\text { conditions. }\end{array}$ & & & ST & FERT & ISR & & \\
\hline TRIANUM-G & $\begin{array}{c}\text { Koppert B.V. } \\
\text { (http://www.koppert. } \\
\text { com/diseases/overvie } \\
\text { w/) }\end{array}$ & $\begin{array}{l}\text { EU, New } \\
\text { Zealand, } \\
\text { Australia }\end{array}$ & $\begin{array}{c}\text { T. harzianum } \\
\text { strain T-22 (Item } \\
\text { 108) }\end{array}$ & R, Annex I & \begin{tabular}{|c|} 
Turf- greens. Increases \\
resistance of plants to \\
stress caused by diseases, \\
sub-optimal feeding and \\
watering. Vegetables, soft \\
fruit, herbs, bulbs, \\
ornamentals, perennials, \\
turf and arboriculture (both \\
protected and open field), \\
regimes or climatic \\
conditions, and increases \\
nutrient uptake; enhanced \\
growth and development \\
of roots and above-ground \\
plant parts.
\end{tabular} & & Granules & $\mathrm{F}$ & ST & FERT & ISR & & \\
\hline TRIANUM-P & $\begin{array}{c}\text { Koppert B.V. } \\
\text { (http://www.koppert. } \\
\text { com/diseases/overvie } \\
\text { w/) }\end{array}$ & $\begin{array}{l}\text { EU, New } \\
\text { Zealand, } \\
\text { Australia }\end{array}$ & $\begin{array}{c}\text { T. harzianum } \\
\text { strain T-22 (Item } \\
\text { 108) }\end{array}$ & R, Annex I & \begin{tabular}{|c|} 
Tomato, Turf- greens. \\
Increases resistance of \\
plants to stress caused by \\
diseases, sub-optimal \\
feeding and watering. \\
Vegetables, soft fruit, \\
herbs, bulbs, ornamentals, \\
perennials, turf and \\
arboriculture (both \\
protected and open field), \\
regimes or climatic \\
conditions, and increases \\
nutrient uptake; enhanced \\
growth and development \\
of roots and above-ground \\
plant parts.
\end{tabular} & $\begin{array}{c}\text { Fusarium } \text { sp., Pythium } \\
\text { sp. }\end{array}$ & $\begin{array}{l}\text { WP, drench, } \\
\text { irrigation - } \\
\text { propagation, } \\
\text { sowing, } \\
\text { transplant }\end{array}$ & $\mathrm{F}$ & ST & FERT & ISR & & \\
\hline $\begin{array}{c}\text { Trichodermas } \\
\text { BioFlower }\end{array}$ & $\begin{array}{c}\text { Terranaturale } \\
\text { (http://www.terranatu } \\
\text { rale.com/) }\end{array}$ & Spain & T. harzianum & $\begin{array}{l}\text { Available } \\
\text { for use, }\end{array}$ & $\begin{array}{c}\text { Biological control, } \\
\text { biostimulant, increased } \\
\text { assimilation of nutrients }\end{array}$ & $\begin{array}{c}\text { Diverse root } \\
\text { pathogenic funghi } \\
\text { (Rhizoctonia, } \\
\text { Fusarium, Pythium, } \\
\text { etc) }\end{array}$ & WP & $\mathrm{F}$ & ST & FERT & & & \\
\hline
\end{tabular}


Appendix 1. contd...

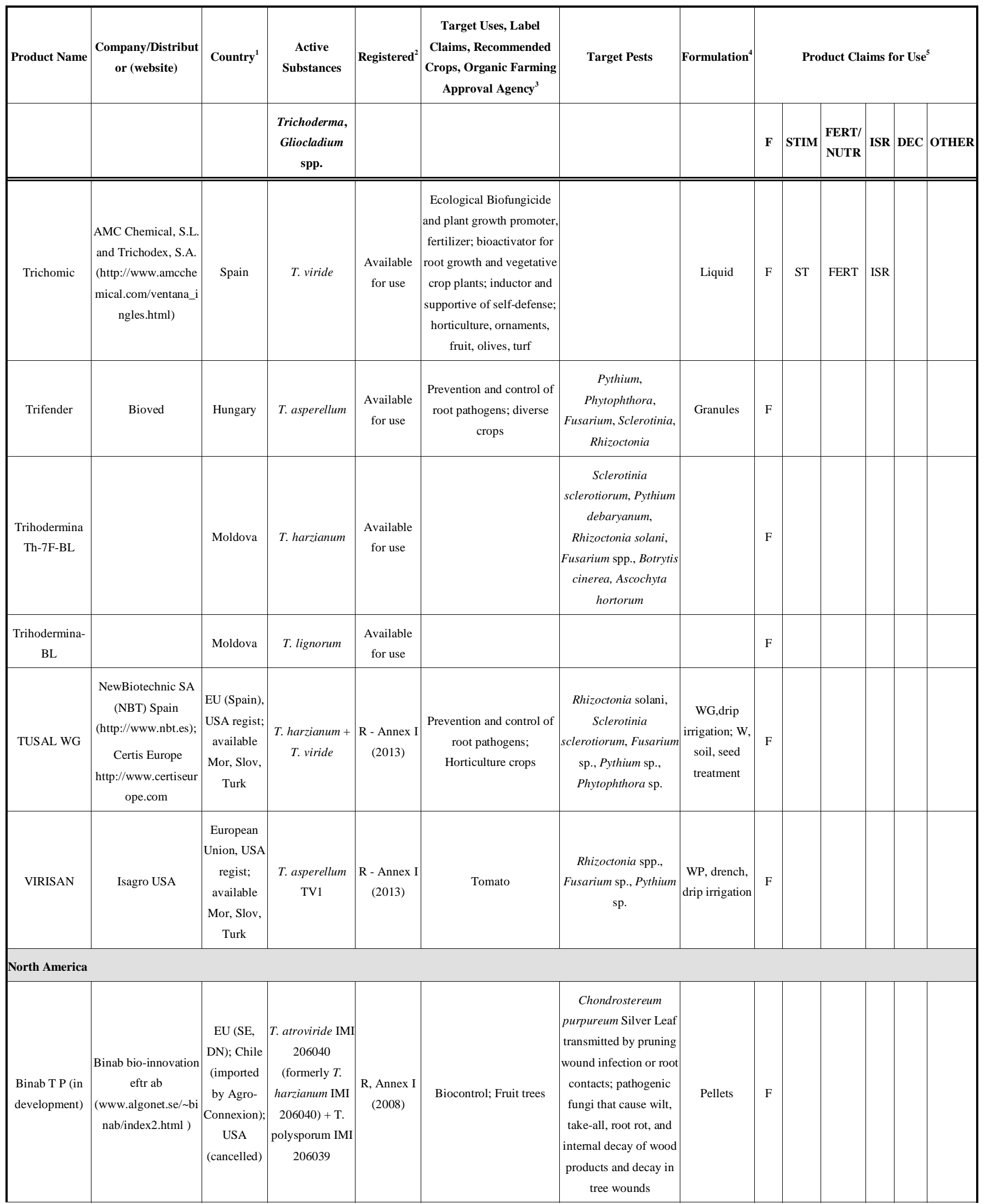


Appendix 1. contd...

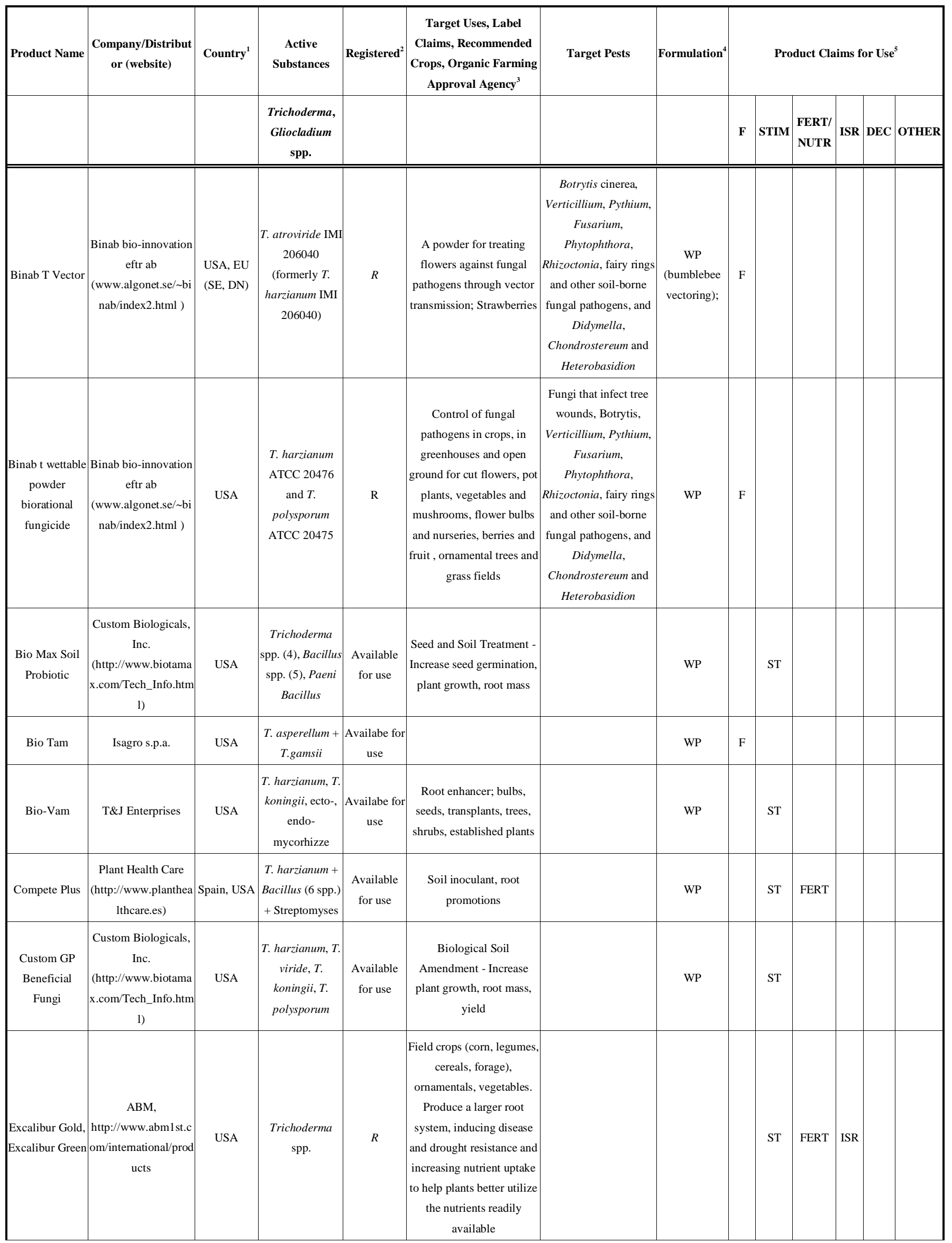


Appendix 1. contd...

\begin{tabular}{|c|c|c|c|c|c|c|c|c|c|c|c|c|c|}
\hline \multirow[t]{2}{*}{ Product Name } & \multirow[t]{2}{*}{$\begin{array}{c}\text { Company/Distribut } \\
\text { or (website) }\end{array}$} & \multirow[t]{2}{*}{ Country $^{1}$} & \multirow{2}{*}{$\begin{array}{c}\text { Active } \\
\text { Substances } \\
\begin{array}{c}\text { Trichoderma, } \\
\text { Gliocladium } \\
\text { spp. }\end{array}\end{array}$} & \multirow[t]{2}{*}{ Registered $^{2}$} & \multirow{2}{*}{\begin{tabular}{|c|} 
Target Uses, Label \\
Claims, Recommended \\
Crops, Organic Farming \\
Approval Agency $^{3}$
\end{tabular}} & \multirow[t]{2}{*}{ Target Pests } & \multirow[t]{2}{*}{ Formulation $^{4}$} & \multicolumn{6}{|c|}{ Product Claims for Use $\mathrm{e}^{5}$} \\
\hline & & & & & & & & $\mathbf{F}$ & STIM & $\begin{array}{l}\text { FERT/ } \\
\text { NUTR }\end{array}$ & ISR & DEC & OTHER \\
\hline Floragard & $\begin{array}{c}\text { Sellew \& associates } \\
1 \mathrm{lc}\end{array}$ & USA & $\begin{array}{l}\text { T. hamatum } \\
\text { isolate } 382\end{array}$ & $\mathrm{R}$ & & & & $\mathrm{F}$ & & & & & \\
\hline $\begin{array}{l}\text { G-41 Technical, } \\
\text { BW240 G, } \\
\text { BW240 WP } \\
\text { Biological } \\
\text { Fungicide } \\
\text { (Bioworks inc) }\end{array}$ & $\begin{array}{c}\text { Bioworks inc } \\
\text { (http://www.biowork } \\
\text { sinc.com/) }\end{array}$ & USA & T. virens $\mathrm{G}-41$ & $\mathrm{R}$ & $\begin{array}{c}\text { Agricultural, greenhouse, } \\
\text { and nursery crops, as well } \\
\text { as plants in residential } \\
\text { settings (vegetables, fruit, } \\
\text { and ornamentals) }\end{array}$ & $\begin{array}{c}\text { control soilborne plant } \\
\text { pathogens and plant } \\
\text { root diseases }\end{array}$ & $\begin{array}{l}\text { wp, Granules } \\
\text { (seed, } \\
\text { propagation } \\
\text { material, } \\
\text { drench, spray) }\end{array}$ & $\mathrm{F}$ & & & & & \\
\hline GlioMix & $\begin{array}{c}\text { Verdera Oy ( } \\
\text { Formerly Kemira } \\
\text { Agro Oy), } \\
\text { http://www.verdera.fi } \\
\text { /homeeng.html }\end{array}$ & $\begin{array}{l}\text { USA; } \\
\text { Finland, } \\
\text { Germany }\end{array}$ & Gliocladium spp. & $\mathrm{R}$ & $\begin{array}{c}\text { Prevention and control of } \\
\text { soilborne pathogens; } \\
\text { ornamentals and diverse } \\
\text { crops }\end{array}$ & & $\begin{array}{l}\text { WP (soil, } \\
\text { substrate) }\end{array}$ & $\mathrm{F}$ & & & & & \\
\hline $\begin{array}{l}\text { Oregonism XL } \\
\text { Root Organics }\end{array}$ & $\begin{array}{c}\text { Aurora Innovations, } \\
\text { http://www.aurorainn } \\
\text { ovations.org/oregonis } \\
\text { m_xl.html }\end{array}$ & $\begin{array}{l}\text { USA, } \\
\text { Canada }\end{array}$ & $\begin{array}{l}\text { Trichoderma } \\
\text { spp. }\end{array}$ & $\begin{array}{c}\text { Available } \\
\text { for use }\end{array}$ & $\begin{array}{c}\text { Biostimulant, increased } \\
\text { nutrient uptake, drought } \\
\text { tolerance, pathogen } \\
\text { resistance }\end{array}$ & & $\begin{array}{l}\text { potting soil, } \\
\text { hydroponics }\end{array}$ & & ST & FERT & ISR & & \\
\hline Plant Helper & $\begin{array}{c}\text { AmPac Biotech, } \\
\text { Fresno CA } \\
\text { (http://www.ampacbi } \\
\text { otech.net/products/m } \\
\text { ain.htm) }\end{array}$ & USA & $\begin{array}{l}\text { T. atroviride } \\
\text { (cold tolerant) }\end{array}$ & $\begin{array}{c}\text { Available } \\
\text { for use }\end{array}$ & $\begin{array}{c}\text { Plant Growth promotion, } \\
\text { natural disease resistance; } \\
\text { allow plants to absorb } \\
\text { more nutrients from the } \\
\text { soil and enhance water } \\
\text { transport while } \\
\text { maintaining plant health all } \\
\text { season long }\end{array}$ & & $\begin{array}{l}\text { Liquid, } \\
\text { Flowable }\end{array}$ & $\mathrm{F}$ & ST & FERT & & & \\
\hline PlantShield HC & $\begin{array}{c}\text { Bioworks inc } \\
\text { (http://www.biowork } \\
\text { sinc.com/) }\end{array}$ & USA & $\begin{array}{l}\text { T. harzianum } \\
\text { Rifai strain } \\
\text { KRL-AG2 }\end{array}$ & $\begin{array}{c}\mathrm{R}, \text { Active } \\
\text { (California } \\
\text { only) }\end{array}$ & \begin{tabular}{|c|} 
Drench into soil for \\
nursery, greenhouse and \\
vegetables; Pathogen \\
control, promotes a \\
healthier root system, \\
increasing root mass \\
potential; media \\
incorporation - nursery, \\
greenhouse and vegetables
\end{tabular} & $\begin{array}{c}\text { Root disease control, } \\
\text { foliar spray to prevent } \\
\text { Botrytis and mildews } \\
\text { on ornamentals }\end{array}$ & WP, drench & $\mathrm{F}$ & ST & FERT & & & \\
\hline $\begin{array}{l}\text { Prestop; Prestop } \\
\text { Mix; Primastop }\end{array}$ & $\begin{array}{c}\text { Verdera Oy } \\
\text { (Formerly Kemira } \\
\text { Agro Oy) }\end{array}$ & $\begin{array}{c}\text { Canada, } \\
\text { USA }\end{array}$ & $\begin{array}{l}\text { Gliocladium } \\
\text { catenulatum } \\
\text { J1446 }\end{array}$ & $\mathrm{R}$ & $\begin{array}{c}\text { For efficient control of soil } \\
\text { and foliar pathogens on } \\
\text { greenhouse vegetables and } \\
\text { ornamentals, herbs, } \\
\text { seedling production, } \\
\text { control of grey mould on } \\
\text { strawberry and raspberry }\end{array}$ & \begin{tabular}{|} 
Control of soil and \\
foliar pathogens \\
Pythium sp., \\
Rhizoctonia sp., \\
Botrytis, Phytophthora, \\
Fusarium, Verticillium, \\
Alternaria, \\
Cladosporium, \\
Helminthosporium, \\
Penicillium, Plicaria, \\
Didymella
\end{tabular} & $\begin{array}{c}\text { WP (drench, } \\
\text { dip, spray, } \\
\text { soil) }\end{array}$ & $\mathrm{F}$ & & & & & \\
\hline
\end{tabular}


Appendix 1. contd...

\begin{tabular}{|c|c|c|c|c|c|c|c|c|c|c|c|c|c|}
\hline \multirow[t]{2}{*}{ Product Name } & \multirow{2}{*}{$\begin{array}{c}\text { Company/Distribut } \\
\text { or (website) }\end{array}$} & \multirow[t]{2}{*}{ Country $^{1}$} & \multirow{2}{*}{\begin{tabular}{|c|} 
Active \\
Substances \\
$\begin{array}{c}\text { Trichoderma, } \\
\text { Gliocladium } \\
\text { spp. }\end{array}$ \\
\end{tabular}} & \multirow[t]{2}{*}{ Registered $^{2}$} & \multirow{2}{*}{$\begin{array}{c}\text { Target Uses, Label } \\
\text { Claims, Recommended } \\
\text { Crops, Organic Farming } \\
\text { Approval Agency }^{3}\end{array}$} & \multirow[t]{2}{*}{ Target Pests } & \multirow[t]{2}{*}{ Formulation $^{4}$} & \multicolumn{6}{|c|}{ Product Claims for Use ${ }^{5}$} \\
\hline & & & & & & & & $\mathbf{F}$ & STIM & $\begin{array}{l}\text { FERT/ } \\
\text { NUTR }\end{array}$ & ISR & DEC & OTHER \\
\hline Remedier WP & Isagro USA & \begin{tabular}{|c} 
European \\
Union, USA \\
regist; \\
available \\
Mor, Slov, \\
Turk
\end{tabular} & \begin{tabular}{|} 
T. asperellum \\
strain ICC $012+$ \\
T. gamsii \\
ICC080
\end{tabular} & $\begin{array}{c}\text { R - Annex I } \\
\text { (2013) }\end{array}$ & Tomato & $\begin{array}{c}\text { Rhizoctonia } \text { spp., } \\
\text { Fusarium sp., Pythium } \\
\text { sp. }\end{array}$ & $\begin{array}{l}\text { WP (drench, } \\
\text { drip } \\
\text { irrigation) }\end{array}$ & $\mathrm{F}$ & & & & & \\
\hline $\begin{array}{c}\text { Root guardian } \\
\text { biofungicide for } \\
\text { soilborne } \\
\text { diseases }\end{array}$ & $\begin{array}{c}\text { Gardens alive! Inc } \\
\text { (http://www.gardensa } \\
\text { live.com/) }\end{array}$ & USA & $\begin{array}{l}\text { T. harzianum } \\
\text { Rifai strain } \\
\text { KRL-AG2 }\end{array}$ & $\mathrm{R}$ & $\begin{array}{c}\text { Application to seeds, plant } \\
\text { roots and soil for control of } \\
\text { plant root diseases; } \\
\text { preventative control of root } \\
\text { diseases of vegetable, } \\
\text { flower and ornamental } \\
\text { plants, promotes bigger, } \\
\text { faster-growing, vigorous } \\
\text { root systems, releases } \\
\text { compounds that make } \\
\text { nutrients more available to } \\
\text { plants }\end{array}$ & & Granules & $\mathrm{F}$ & ST & FERT & & & \\
\hline $\begin{array}{c}\text { RootShield } \\
\text { PLUS WP, } \\
\text { RootShield } \\
\text { (WP, Granules), } \\
\text { RootShield HC }\end{array}$ & $\begin{array}{c}\text { Bioworks inc } \\
\text { (http://www.biowork } \\
\text { sinc.com) }\end{array}$ & $\begin{array}{c}\text { USA, } \\
\text { Canada, EU }\end{array}$ & $\begin{array}{c}\text { T. harzianum } \\
\text { Rifai strain T-22 } \\
\text { (KRL-AG2) }\end{array}$ & $\mathrm{R}$ & \begin{tabular}{|c|} 
Horticulture and \\
agriculture. Pathogen \\
control, promotes a \\
healthier root system, \\
increasing root mass \\
potential. For media \\
incorporation - nursery, \\
greenhouse and vegetables; \\
Drench for use on nursery, \\
greenhouse and vegetables
\end{tabular} & $\begin{array}{c}\text { Root disease control } \\
\text { Fusarium, Pythium, } \\
\text { Rhizoctonia, } \\
\text { Thielaviopsis and } \\
\text { Cylindrocladium; } \\
\text { PLUS Phytophthora, } \\
\text { Pythium (P. } \\
\text { aphanidermatum), }\end{array}$ & $\begin{array}{c}\text { WP, } \\
\text { Granules, } \\
\text { seed, } \\
\text { propagation } \\
\text { material, } \\
\text { drench, dip, } \\
\text { spray }\end{array}$ & $\mathrm{F}$ & ST & FERT & ISR & & \\
\hline SoilGard 12G & $\begin{array}{c}\text { AgBio Development } \\
\text { Inc. , Certis USA, } \\
\text { LLC } \\
\text { (http://www.certisusa } \\
\text {.com/) }\end{array}$ & USA & $\begin{array}{l}\text { Gliocladium } \\
\text { virens GL-21 } \\
\text { (Trichderma } \\
\text { virens) }\end{array}$ & $\mathrm{R}$ & $\begin{array}{c}\text { Preventative disease } \\
\text { control (not curative) in } \\
\text { ornamental and food crop } \\
\text { plants grown in } \\
\text { greenhouses, nurseries, } \\
\text { homes, and interiorscapes }\end{array}$ & $\begin{array}{c}\text { Sclerotinia minor \& S. } \\
\text { sclerotiorum, Pythium, } \\
\text { Rhizoctonia and } \\
\text { Fusarium }\end{array}$ & $\begin{array}{l}\text { Granules (soil } \\
\text { incorporation) }\end{array}$ & $\mathrm{F}$ & & & & & \\
\hline $\begin{array}{l}\text { T. gamsii icc } \\
080 \text { technical }\end{array}$ & Isagro s.p.a. & USA & T. gamsii & R Active & & & & $\mathrm{F}$ & & & & & \\
\hline $\begin{array}{l}\text { T-22 HC, } \\
\text { technical, } \\
\text { biological } \\
\text { fungicide }\end{array}$ & $\begin{array}{c}\text { Bioworks inc } \\
\text { (http://www.biowork } \\
\text { sinc.com/) }\end{array}$ & USA & $\begin{array}{l}\text { T. harzianum } \\
\text { Rifai strain } \\
\text { KRL-AG2 }\end{array}$ & $\mathrm{R}$ (Active) & \begin{tabular}{|c} 
Use for seed treatment, \\
transplants, planting mixes, \\
in-furrow applications; \\
protection root pathogens, \\
enhances nutrient \\
utilization, increases stress \\
tolerance
\end{tabular} & $\begin{array}{c}\text { Root disease control } \\
\text { Pythium, Rhizoctonia, } \\
\text { Fusarium, } \\
\text { Cylindrocladium and } \\
\text { Thielaviopsis }\end{array}$ & wp, Granules & $\mathrm{F}$ & ST & FERT & ISR & & \\
\hline
\end{tabular}


Appendix 1. contd...

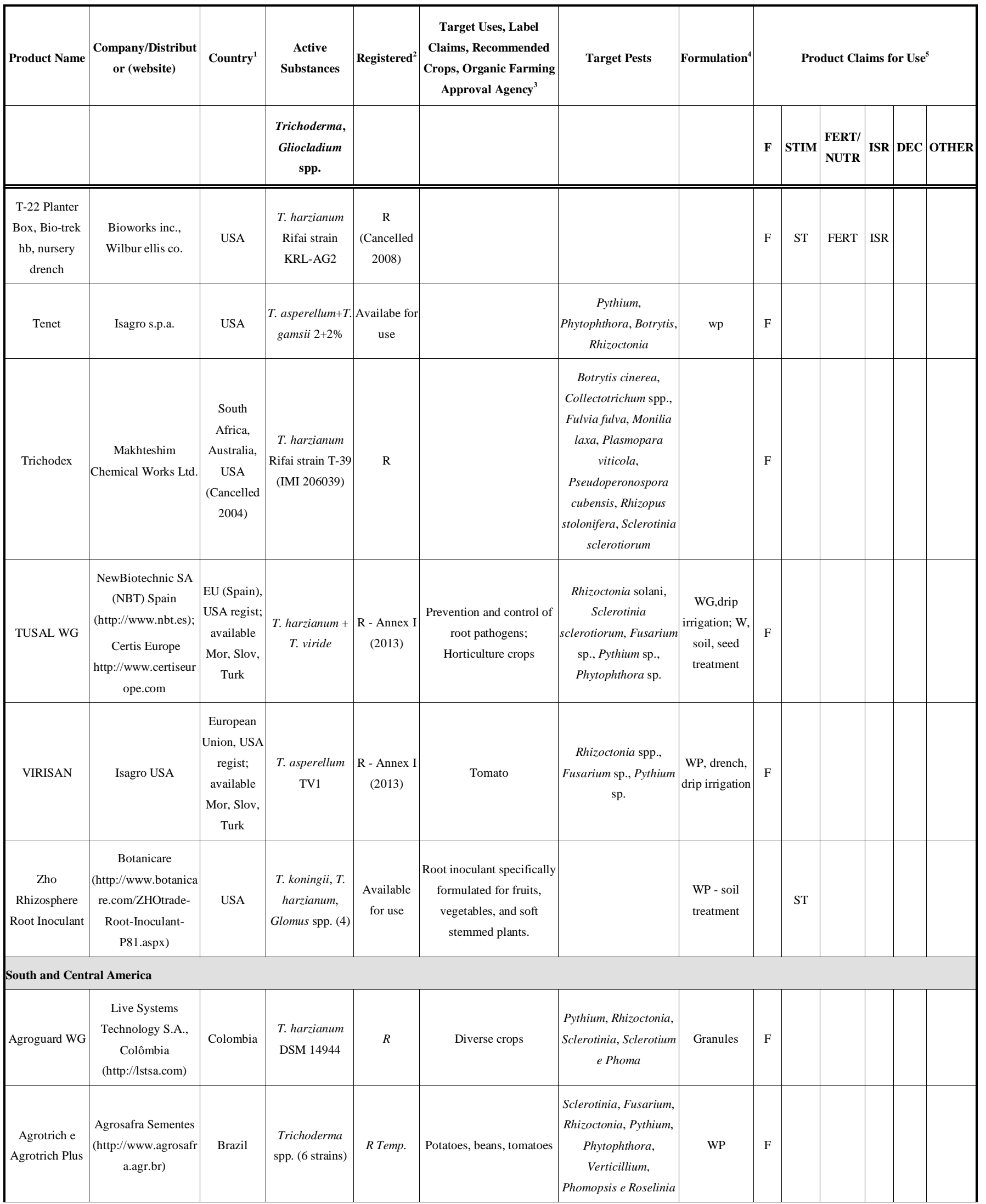


Appendix 1. contd...

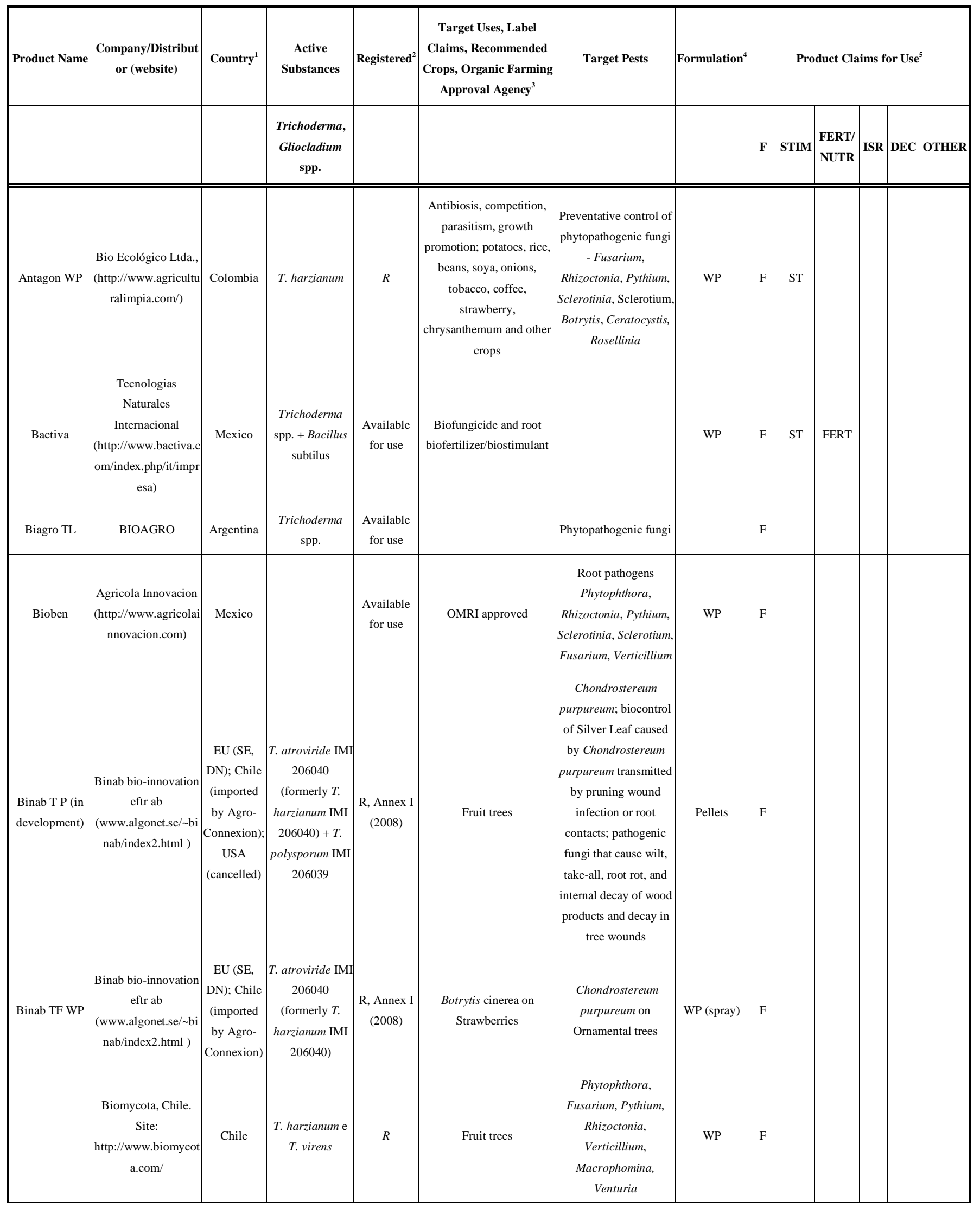


Appendix 1. contd...

\begin{tabular}{|c|c|c|c|c|c|c|c|c|c|c|c|c|c|}
\hline \multirow[t]{2}{*}{ Product Name } & \multirow[t]{2}{*}{$\begin{array}{c}\text { Company/Distribut } \\
\text { or (website) }\end{array}$} & \multirow[t]{2}{*}{ Country $^{1}$} & \multirow{2}{*}{\begin{tabular}{|c|} 
Active \\
Substances \\
$\begin{array}{c}\text { Trichoderma, } \\
\text { Gliocladium } \\
\text { spp. }\end{array}$ \\
\end{tabular}} & \multirow[t]{2}{*}{ Registered $^{2}$} & \multirow{2}{*}{\begin{tabular}{|c|} 
Target Uses, Label \\
Claims, Recommended \\
Crops, Organic Farming \\
Approval Agency $^{3}$
\end{tabular}} & \multirow[t]{2}{*}{ Target Pests } & \multirow[t]{2}{*}{ Formulation $^{4}$} & \multicolumn{6}{|c|}{ Product Claims for Use $\mathrm{e}^{5}$} \\
\hline & & & & & & & & $\mathbf{F}$ & STIM & $\begin{array}{l}\text { FERT/ } \\
\text { NUTR }\end{array}$ & ISR & DEC & OTHER \\
\hline Bio Traz & $\begin{array}{c}\text { Biomycota, Chile. } \\
\text { Site: } \\
\text { http://www.biomycot } \\
\text { a.com/ }\end{array}$ & Chile & $\begin{array}{c}\text { T. harzianum e } \\
\text { T. virens }\end{array}$ & $R$ & $\begin{array}{c}\text { Protecting the plant from } \\
\text { pathogens, nutrient } \\
\text { competition }\end{array}$ & $\begin{array}{c}\text { Recommended for } \\
\text { control of foliar/aerial } \\
\text { diseases caused by } \\
\text { Botrytis in grape, } \\
\text { Monilinia on stone } \\
\text { fruits and cherries. }\end{array}$ & WP & $\mathrm{F}$ & & FERT & & & \\
\hline BioFungo WP & $\begin{array}{c}\text { Orius Biotecnología } \\
\text { (http://www.oriusbiot } \\
\text { ecnologia.com) }\end{array}$ & $\begin{array}{l}\text { Colombia, } \\
\text { Equador }\end{array}$ & $\begin{array}{l}\text { T. harzianum } \\
\text { ATCC } 52443\end{array}$ & $\begin{array}{c}\text { R Colombia, } \\
\text { Equador }\end{array}$ & Biofungicide & $\begin{array}{c}\text { Botrytis cinerea e } \\
\text { Sphaerotheca pannosa } \\
\text { on roses }\end{array}$ & WP & $\mathrm{F}$ & & & & & \\
\hline $\begin{array}{c}\text { Bioprotection } \\
\text { TR }\end{array}$ & $\begin{array}{c}\text { Laboratorios Doctor } \\
\text { Obregón } \\
\text { (http://www.doctor- } \\
\text { obregon.com/Pages/d } \\
\text { efault.aspx) }\end{array}$ & Costa Rica & T. asperellum & $\begin{array}{c}\text { Availabe for } \\
\text { use }\end{array}$ & $\begin{array}{c}\text { Antagonistic fungus, } \\
\text { stimulates resistance and } \\
\text { plant growth promoter }\end{array}$ & $\begin{array}{c}\text { Rhizoctonia Pythium. } \\
\text { Phytophthora, } \\
\text { Fusarium, Rhizopus, } \\
\text { Mucor, Botrytis, } \\
\text { Colletotrichum }\end{array}$ & $\begin{array}{l}\text { WP, Solid } \\
\text { (rice), Liquid } \\
\text { contains } \\
\text { fungus and } \\
\text { culture filtrate }\end{array}$ & $\mathrm{F}$ & ST & & ISR & & \\
\hline Biorend $\mathrm{T}$ & $\begin{array}{c}\text { pela Bioagro S.A.; } \\
\text { Biotex S.A. } \\
\text { (http://www.biorend. } \\
\text { cl) }\end{array}$ & Chile & $\begin{array}{l}\text { T. harzianum } \\
\text { and chitosan }\end{array}$ & $\begin{array}{l}\text { Available } \\
\text { for use }\end{array}$ & $\begin{array}{c}\text { Induction of the } \\
\text { mechanism of defence of } \\
\text { the plant }\end{array}$ & $\begin{array}{c}\text { Phytophthora, } \\
\text { Pythium, Rhizoctonia, } \\
\text { Fusarium, } \\
\text { Cylindrocarpon, } \\
\text { Verticillium } \text { e Botrytis } \\
\text { cinerea. }\end{array}$ & $\begin{array}{l}\text { WP seed, root } \\
\text { dip, foliar, } \\
\text { irrigazione }\end{array}$ & & & & ISR & & \\
\hline Biotrich & $\begin{array}{c}\text { Biovale Produtos } \\
\text { Agropecuários Ltd. } \\
\text { (http://www.biovale. } \\
\text { com.br) }\end{array}$ & Brazil & $\begin{array}{l}\text { T. viride (1 } \\
\text { strain), } T \text {. } \\
\text { harzianum (3 } \\
\text { isolates) }\end{array}$ & $\begin{array}{l}\text { Available } \\
\text { for use }\end{array}$ & Diverse crops & $\begin{array}{c}\text { Rhizoctonia, } \\
\text { Phytophthora, } \\
\text { Sclerotinia, Fusarium, } \\
\text { Verticillium, Pythium, } \\
\text { Phomopsis, Rosellinia, } \\
\text { Pasmodiophora }\end{array}$ & $\begin{array}{l}\text { WP for } \\
\text { irrigation }\end{array}$ & $\mathrm{F}$ & & & & & \\
\hline Ecotrich ES & $\begin{array}{c}\text { Ballagro Agro } \\
\text { Tecnologia Ltd } \\
\text { (http://www.ballagro. } \\
\text { com.br) }\end{array}$ & Brazil & T. harzianum & $\begin{array}{l}\text { R, Special } \\
\text { Temp. } \\
\text { Regist. in } \\
\text { Brazil }\end{array}$ & $\begin{array}{c}\text { Lettuce, cotton, potatoes, } \\
\text { onion, ginger, carrot, } \\
\text { sunflower, beans, tobacco, } \\
\text { corn, strawberry, cabbage, } \\
\text { soya, tomatoes, wheat }\end{array}$ & $\begin{array}{c}\text { Rhizoctonia solani in } \\
\text { beans, strawberry and } \\
\text { soya, Sclerotinia spp. } \\
\text { in beans and soya, } \\
\text { Pythium in lettuce }\end{array}$ & Liquid, seed & $\mathrm{F}$ & & & & & \\
\hline Fitotripen WP & $\begin{array}{c}\text { Safer Agrobiologicos } \\
\text { http://www.agrobiolo } \\
\text { gicossafer.com/jooml } \\
\text { a2009/ }\end{array}$ & Colombia & $\begin{array}{c}\text { T. harzianum, } T \text {. } \\
\text { koningii, } T \text {. } \\
\text { viride }\end{array}$ & $\mathrm{R}$ & Diverse crops & $\begin{array}{c}\text { Fusarium, Rhizoctonia, } \\
\text { Sclerotiinia, Botrytis, } \\
\text { Mycosphaerella }\end{array}$ & WP & $\mathrm{F}$ & & & & & \\
\hline Foliguard & $\begin{array}{c}\text { Live Systems } \\
\text { Technology S.A } \\
\text { (http://www.lstsa.co } \\
\text { m/) }\end{array}$ & Colombia & $\begin{array}{l}\text { T. harzianum } \\
\text { DSM } 14944\end{array}$ & $\mathrm{R}$ & Diverse crops; preventive & $\begin{array}{c}\text { Botrytis cinerea, } \\
\text { Sphaerotheca pannosa, } \\
\text { Oidium, Alternaria e } \\
\text { Cladosporium }\end{array}$ & Liquid & $\mathrm{F}$ & & & & & \\
\hline $\begin{array}{c}\text { ICB Nutrisolo } \\
\text { SC e WP }\end{array}$ & $\begin{array}{c}\text { ICB BIOAGRITEC } \\
\text { Ltd }\end{array}$ & Brazil & $\begin{array}{l}\text { T. viride, } T \text {. } \\
\text { harzianum, } T \text {. } \\
\text { koningii, } \\
\text { Trichoderma } \\
\text { spp. }\end{array}$ & R, Temp. & $\begin{array}{l}\text { Soilborne pathogens; } \\
\text { diverse crops }\end{array}$ & $\mid \begin{array}{c}\text { Fusarium, Rhizoctonia, } \\
\text { Pythium, Phytophthora } \\
\text { e Sclerotinia }\end{array}$ & WP & $\mathrm{F}$ & & & & & \\
\hline
\end{tabular}


Appendix 1. contd...

\begin{tabular}{|c|c|c|c|c|c|c|c|c|c|c|c|c|c|}
\hline \multirow[t]{2}{*}{ Product Name } & \multirow{2}{*}{$\begin{array}{c}\text { Company/Distribut } \\
\text { or (website) }\end{array}$} & \multirow[t]{2}{*}{ Country $^{1}$} & \multirow{2}{*}{$\begin{array}{c}\text { Active } \\
\text { Substances } \\
\begin{array}{c}\text { Trichoderma, } \\
\text { Gliocladium } \\
\text { spp. }\end{array}\end{array}$} & \multirow[t]{2}{*}{ Registered $^{2}$} & \multirow{2}{*}{$\begin{array}{c}\text { Target Uses, Label } \\
\text { Claims, Recommended } \\
\text { Crops, Organic Farming } \\
\text { Approval Agency }^{3}\end{array}$} & \multirow[t]{2}{*}{ Target Pests } & \multirow[t]{2}{*}{ Formulation $^{4}$} & \multicolumn{6}{|c|}{ Product Claims for Use ${ }^{5}$} \\
\hline & & & & & & & & $\mathbf{F}$ & STIM & $\begin{array}{l}\text { FERT/ } \\
\text { NUTR }\end{array}$ & ISR & DEC & OTHER \\
\hline Mycobac WP & $\begin{array}{c}\text { Laboratórios } \\
\text { Laverlam } \\
\text { (http//www.laverlam. } \\
\text { net/catalogo/es/linea- } \\
\text { agricola) }\end{array}$ & $\begin{array}{l}\text { Honduras, } \\
\text { Colombia }\end{array}$ & T. lignorum & $\begin{array}{l}\text { Available } \\
\text { for use }\end{array}$ & Diverse crops & $\begin{array}{c}\text { Rhizoctonia, } \\
\text { Sclerotinia, Fusarium, } \\
\text { Botrytis, Sclerotium, } \\
\text { Rosellinia, Pythium, } \\
\text { Armillaria, Alternaria } \\
\text { and nematodes }\end{array}$ & & $\mathrm{F}$ & & & & & NEM \\
\hline Natibiol & $\begin{array}{c}\text { Probiagro S.A., } \\
\text { Acarigua, Venezuela }\end{array}$ & Venezuela & T. harzianum & $\begin{array}{l}\text { Available } \\
\text { for use }\end{array}$ & Diverse crops & Rhizoctonia & & $\mathrm{F}$ & & & & & \\
\hline NatuControl & $\begin{array}{c}\text { Biokrone } \\
\text { (http://www.biokrone } \\
\text {.com) }\end{array}$ & Mexico & T. harzianum & $\begin{array}{l}\text { Available } \\
\text { for use }\end{array}$ & $\begin{array}{l}\text { Biofungicide, activate } \\
\text { defence mechanisms, } \\
\text { growth promotion } \\
\text { (fitoalexin production), } \\
\text { increased nutrient } \\
\text { absorbtion; OMRI } \\
\text { approved }\end{array}$ & $\begin{array}{c}\text { Root fungal pathogens } \\
\text { Fusarium, } \\
\text { Phytophthora etc. }\end{array}$ & WP & $\mathrm{F}$ & ST & FERT & ISR & & \\
\hline $\begin{array}{c}\text { PHC T-22, PHC } \\
\text { PlanterBox }\end{array}$ & $\begin{array}{c}\text { Plant Health Care } \\
\text { Mexico } \\
\text { (http://www.phcmexi } \\
\text { co.com) }\end{array}$ & Mexico & $\begin{array}{l}\text { T. harzianum } \\
\text { strain T-22 } \\
\text { (KRL-AG2) }\end{array}$ & $\mathrm{R}$ & $\begin{array}{c}\text { Horticulture crops. } \\
\text { Pathogen control, } \\
\text { promotes a healthier root } \\
\text { system, increasing root } \\
\text { mass potential; OMRI } \\
\text { approved }\end{array}$ & $\begin{array}{l}\text { Root disease control } \\
\text { Fusarium, Pythium, } \\
\text { Rhizoctonia, } \\
\text { Thielaviopsis and } \\
\text { Cylindrocladium }\end{array}$ & $\begin{array}{c}\text { WP, Granules } \\
\text { (seed, } \\
\text { propagation } \\
\text { material, } \\
\text { drench, dip, } \\
\text { spray) }\end{array}$ & $\mathrm{F}$ & ST & FERT & ISR & & \\
\hline Quality WG & $\begin{array}{c}\text { Laboratório de } \\
\text { Biocontrole } \\
\text { Farroupilha Ltda. } \\
\text { (http://www.grupofar } \\
\text { roupilha.com/) }\end{array}$ & Brazil & T. asperellum & $R$ & Soya, beans and cotton & Soil pathogens & Granules & $\mathrm{F}$ & & & & & \\
\hline Tricho D WP & $\begin{array}{c}\text { Orius Biotecnologia } \\
\text { /Colômbia, } \\
\text { (http://www.oriusbiot } \\
\text { ecnologia.com/) }\end{array}$ & $\begin{array}{l}\text { Colombia, } \\
\text { Equador, } \\
\text { Panama, } \\
\text { Peru, Chile }\end{array}$ & $\begin{array}{c}\text { T. harzianum T- } \\
22 \text { (ATCC } \\
\text { 20847) }\end{array}$ & $R$ & $\begin{array}{c}\text { Diverse crops - } \\
\text { horticulture, ornamentals, } \\
\text { fruits }\end{array}$ & $\begin{array}{c}\text { Rhizoctonia, } \\
\text { Sclerotinia, Fusarium, } \\
\text { Botrytis, Sclerotium, } \\
\text { Rosellinia, Pythium, } \\
\text { Armillaria, Alternaria }\end{array}$ & WP & $\mathrm{F}$ & & & & & \\
\hline Trichobiol WP & $\begin{array}{c}\text { Control Biológico } \\
\text { Integrado } \\
\text { (http://www.controlb } \\
\text { iologicointegrado.co } \\
\text { m/quienes-somos/); } \\
\text { Mora Jaramillo } \\
\text { Arturo Orlando-- } \\
\text { Biocontrol }\end{array}$ & Colombia & T. harzianum & $R$ & $\begin{array}{l}\text { Antagonistic fungus, } \\
\text { stimulates resistance and } \\
\text { plant growth promoter; } \\
\text { reduces incidence of } \\
\text { nematodes }\end{array}$ & $\begin{array}{c}\text { Rhizoctonia Pythium. } \\
\text { Phytophthora, } \\
\text { Fusarium, Rhizopus, } \\
\text { Mucor, Botrytis, } \\
\text { Colletotrichum }\end{array}$ & WP & $\mathrm{F}$ & ST & & ISR & & NEM \\
\hline Trichodel & $\begin{array}{c}\text { Empresa Caxiense de } \\
\text { Controle Biológico } \\
\text { Ltda } \\
\text { (http://www.eccb.co } \\
\text { m.br) }\end{array}$ & Brazil & $\begin{array}{c}\text { Trichoderma } \\
\text { spp. }\end{array}$ & $R$ & $\begin{array}{l}\text { Horticultural and fruit } \\
\text { crops; hydroponics }\end{array}$ & $\begin{array}{c}\text { Botrytis, Plasmopara, } \\
\text { Fusarium, } \\
\text { Colletotrichum, } \\
\text { Glomerella, } \\
\text { Botryosphaeria, } \\
\text { Alternaria, Penicillium, } \\
\text { Pythium }\end{array}$ & $\begin{array}{c}\text { WP, Liquid } \\
\text { (seed, soil, } \\
\text { propogation } \\
\text { material) }\end{array}$ & $\mathrm{F}$ & & & & & \\
\hline
\end{tabular}


Appendix 1. contd...

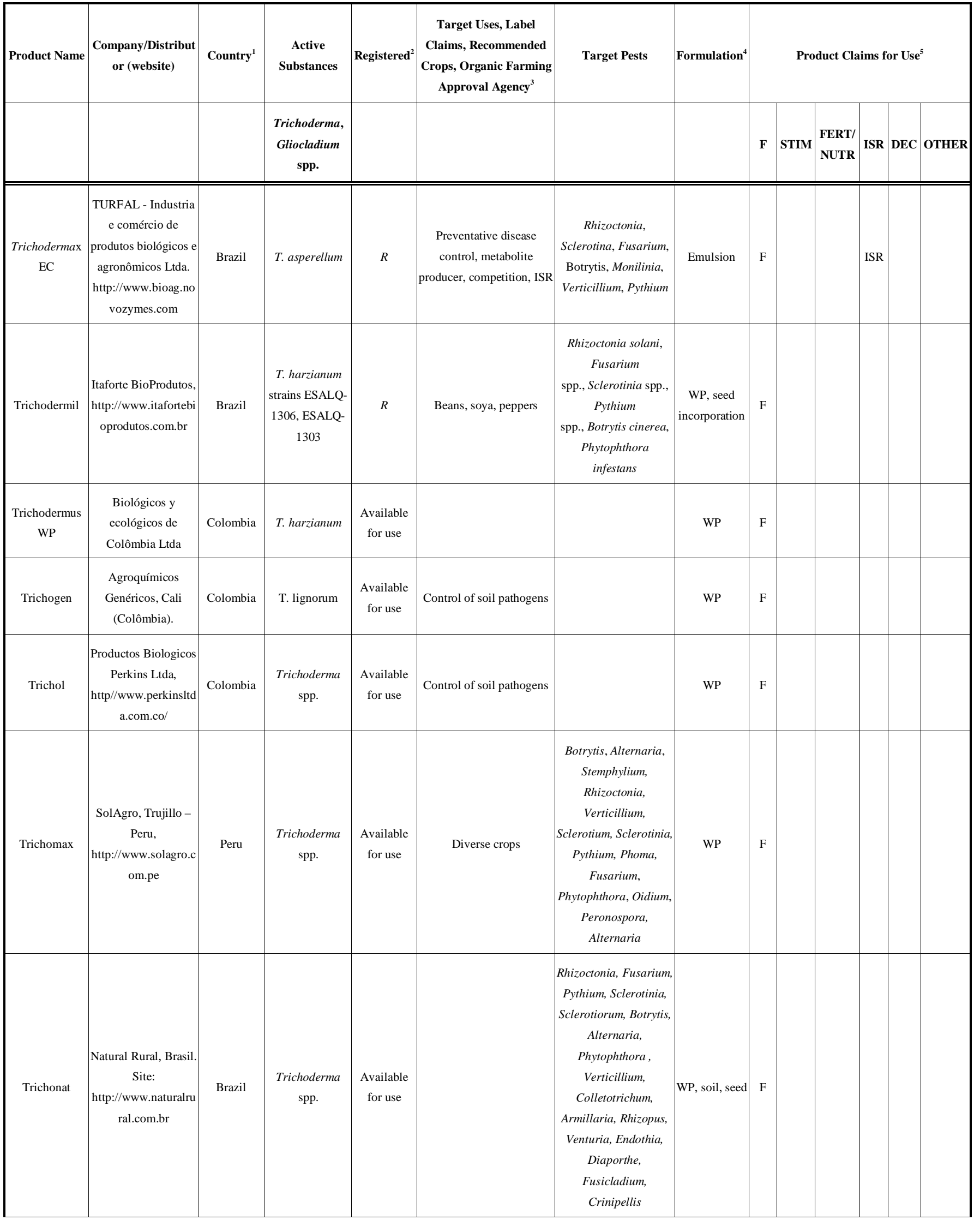


Appendix 1. contd...

\begin{tabular}{|c|c|c|c|c|c|c|c|c|c|c|c|c|c|}
\hline \multirow[t]{2}{*}{ Product Name } & \multirow[t]{2}{*}{$\begin{array}{c}\text { Company/Distribut } \\
\text { or (website) }\end{array}$} & \multirow[t]{2}{*}{ Country $^{1}$} & \multirow{2}{*}{$\begin{array}{c}\text { Active } \\
\text { Substances } \\
\begin{array}{c}\text { Trichoderma, } \\
\text { Gliocladium } \\
\text { spp. }\end{array}\end{array}$} & \multirow[t]{2}{*}{ Registered $^{2}$} & \multirow{2}{*}{$\begin{array}{c}\text { Target Uses, Label } \\
\text { Claims, Recommended } \\
\text { Crops, Organic Farming } \\
\text { Approval Agency }^{3}\end{array}$} & \multirow[t]{2}{*}{ Target Pests } & \multirow[t]{2}{*}{ Formulation $^{4}$} & \multicolumn{6}{|c|}{ Product Claims for Use $\mathrm{e}^{5}$} \\
\hline & & & & & & & & $\mathbf{F}$ & STIM & $\begin{array}{l}\text { FERT/ } \\
\text { NUTR }\end{array}$ & ISR & DEC & OTHER \\
\hline Trichonativa & $\begin{array}{c}\text { Bio-Insumos Nativa } \\
\text { Ltda, } \\
\text { http://www.bionativa } \\
\text {.cl }\end{array}$ & Chile & \begin{tabular}{|c|} 
T. virens, $T$. \\
harzianum, $T$. \\
parceanamosum
\end{tabular} & $\mathrm{R}$ & $\begin{array}{l}\text { Fruit, grapes, tomato, } \\
\text { horticultural crops }\end{array}$ & $\begin{array}{c}\text { Rhizoctonia, Fusarium, } \\
\text { Pythium, Sclerotinia, } \\
\text { Sclerotiorum, Botrytis, } \\
\text { Phytophthora, } \\
\text { Armillaria, Venturia }\end{array}$ & WP & F & & & & & \\
\hline Trichosav-34 & $\begin{array}{c}\text { Institute for Research } \\
\text { in Plant Protection } \\
\text { (INISAV) }\end{array}$ & Cuba & $\begin{array}{c}\text { T. harzianum A- } \\
34\end{array}$ & $\mid \begin{array}{c}\text { R, Use } \\
\text { permit only }\end{array}$ & $\begin{array}{c}\text { Fungicide for control of } \\
\text { soil pathogens in } \\
\text { vegetables and } \\
\text { ornamentals }\end{array}$ & \begin{tabular}{|} 
Rhizoctonia solani, \\
Pythium \\
aphidermatum, \\
Phytophthora \\
parasitica, P. capsici, \\
Sclerotium rolssii, \\
Fusarium spp.
\end{tabular} & $\begin{array}{c}\text { Homemade - } \\
\text { Solid or } \\
\text { Liquid }\end{array}$ & $\mathrm{F}$ & & & & & \\
\hline Trichosoil & Lage S.A., Uruguai & Uraguay & T. harzianum & $\begin{array}{c}\text { Available } \\
\text { for use }\end{array}$ & $\begin{array}{c}\text { Prevention and control of } \\
\text { root pathogens }\end{array}$ & $\begin{array}{c}\text { Fusarium, Sclerotinia } \\
\text { Pythium }\end{array}$ & & F & & & & & \\
\hline Trichoteam & $\begin{array}{c}\text { Bioteam Ind. e Com. } \\
\text { Ltda }\end{array}$ & Brazil & $\begin{array}{l}\text { Trichoderma } \\
\text { spp. }\end{array}$ & $\begin{array}{c}\text { Available } \\
\text { for use }\end{array}$ & Soil conditioner & \begin{tabular}{|c|} 
Fusarium spp.; \\
Rhizoctonia spp., \\
Crinipellis, \\
Phytophthora sp; \\
Colletotrichum, \\
Cylindrocladium spp.; \\
Alternaria helianthi; \\
Sclerotinia \\
sclerotiorum, \\
Rosellinia; Botrytis \\
cinerea; Verticillium \\
dahliae, Plasmopara \\
viticola.
\end{tabular} & & $\mathrm{F}$ & & FERT & & & \\
\hline
\end{tabular}


Appendix 1. contd...

\begin{tabular}{|c|c|c|c|c|c|c|c|c|c|c|c|c|c|}
\hline \multirow[t]{2}{*}{ Product Name } & \multirow[t]{2}{*}{$\begin{array}{c}\text { Company/Distribut } \\
\text { or (website) }\end{array}$} & \multirow[t]{2}{*}{ Country $^{1}$} & \multirow{2}{*}{\begin{tabular}{c|} 
Active \\
Substances \\
$\begin{array}{c}\text { Trichoderma, } \\
\text { Gliocladium } \\
\text { spp. }\end{array}$
\end{tabular}} & \multirow[t]{2}{*}{ Registered $^{2}$} & \multirow{2}{*}{$\begin{array}{c}\text { Target Uses, Label } \\
\text { Claims, Recommended } \\
\text { Crops, Organic Farming } \\
\text { Approval Agency }^{3}\end{array}$} & \multirow[t]{2}{*}{ Target Pests } & \multirow[t]{2}{*}{ Formulation $^{4}$} & \multicolumn{6}{|c|}{ Product Claims for Use $^{5}$} \\
\hline & & & & & & & & $\mathbf{F}$ & STIM & $\begin{array}{l}\text { FERT/ } \\
\text { NUTR }\end{array}$ & ISR & DEC & OTHER \\
\hline Trichozam & $\begin{array}{c}\text { Hardware \& Lumber } \\
\text { Limited (Agro Grace } \\
\text { Division). Centro de } \\
\text { Control Biológico de } \\
\text { Centroamérica de } \\
\text { Zamorano, Honduras }\end{array}$ & $\begin{array}{l}\text { Honduras, } \\
\text { Colombia }\end{array}$ & $\begin{array}{l}\text { Trichoderma } \\
\text { spp. }\end{array}$ & $R$ & $\begin{array}{c}\text { Horticultural, ornamentals, } \\
\text { maize }\end{array}$ & $\mid \begin{array}{l}\text { Fusarium, Rhizoctonia, } \\
\text { Pythium, Phytophthora }\end{array}$ & $\begin{array}{c}\text { Homemade - } \\
\text { Solid or } \\
\text { Liquid }\end{array}$ & $\mathrm{F}$ & & & & & \\
\hline Tricovab & $\begin{array}{c}\text { Comissão Executiva } \\
\text { do Plano da Lavoura } \\
\text { Cacaueira - } \\
\text { CEPLAC, } \\
\text { http://www.ceplac.go } \\
\text { v.br }\end{array}$ & Brazil & $\begin{array}{c}\text { T. stromaticum } \\
\text { strain } 3550\end{array}$ & $\begin{array}{l}\text { Available } \\
\text { for use }\end{array}$ & $\begin{array}{c}\text { Cocoa; use in organic } \\
\text { farming }\end{array}$ & $\begin{array}{c}\text { Moniliophthora } \\
\text { perniciosa }\end{array}$ & WP (conidia) & $\mathrm{F}$ & & & & & \\
\hline Trifesol & $\begin{array}{l}\text { BioCultivos S.A., } \\
\text { Bogotá, Colômbia }\end{array}$ & Colombia & T. viride 2684 & $\begin{array}{l}\text { Available } \\
\text { for use }\end{array}$ & $\begin{array}{c}\text { Prevention and control of } \\
\text { nematodes }\end{array}$ & & WP & & & & & & NEM \\
\hline Colonizer & Metcalf Biologicals & Australia & T. koningii Td67 & $\begin{array}{l}\text { Available } \\
\text { for use }\end{array}$ & $\begin{array}{c}\text { Bio-inoculant; natural } \\
\text { barrier to the early } \\
\text { infection and establishment } \\
\text { of latent infection } \\
\text { of Botrytis in grapes }\end{array}$ & & WP & $\mathrm{F}$ & & & & & \\
\hline \begin{tabular}{c|} 
DRH \\
Trichoderma \\
Products - DRH \\
Fine, DRH CI, \\
DRH Pellets
\end{tabular} & $\begin{array}{c}\text { GroChem NZ Ltd. } \\
\text { http://grochem.co.nz/ }\end{array}$ & $\begin{array}{c}\text { New } \\
\text { Zealand }\end{array}$ & $\begin{array}{c}\text { Trichoderma (5 } \\
\text { isolates) }\end{array}$ & $\begin{array}{l}\text { Available } \\
\text { for use }\end{array}$ & $\begin{array}{l}\text { Beneficial soil fungi for } \\
\text { improving soil microflora. }\end{array}$ & & WP, Pellets & & & FERT & & & \\
\hline Esquive WP & \begin{tabular}{|} 
Agrauxine, ZA de \\
Troyalac'h \\
(http://www.agrauxin \\
e.com/)
\end{tabular} & $\begin{array}{c}\text { Europe } \\
\text { (France), } \\
\text { Australia, } \\
\text { New } \\
\text { Zealand, } \\
\text { South } \\
\text { Africa, } \\
\text { Vietnam }\end{array}$ & $\begin{array}{c}\text { T. atroviride } \\
1237\end{array}$ & $\begin{array}{l}\text { R, Annex I } \\
\text { (2012) }\end{array}$ & $\begin{array}{c}\text { Vineyards, nursery, Grapes } \\
\text { - root, dieback }\end{array}$ & \begin{tabular}{|c|} 
Eutypa, \\
Botryosphaeria spp., \\
Phaeomoniella, \\
Phaeoacremonium
\end{tabular} & $\begin{array}{c}\text { WP, pruning, } \\
\text { dip, aerial } \\
\text { spray }\end{array}$ & $\mathrm{F}$ & & & & & \\
\hline
\end{tabular}


Appendix 1. contd...

\begin{tabular}{|c|c|c|c|c|c|c|c|c|c|c|c|c|c|}
\hline \multirow[t]{2}{*}{ Product Name } & \multirow[t]{2}{*}{$\begin{array}{c}\text { Company/Distribut } \\
\text { or (website) }\end{array}$} & \multirow[t]{2}{*}{ Country $^{1}$} & \multirow{2}{*}{\begin{tabular}{c|} 
Active \\
Substances \\
$\begin{array}{c}\text { Trichoderma, } \\
\text { Gliocladium } \\
\text { spp. }\end{array}$
\end{tabular}} & \multirow[t]{2}{*}{ Registered $^{2}$} & \multirow{2}{*}{$\begin{array}{c}\text { Target Uses, Label } \\
\text { Claims, Recommended } \\
\text { Crops, Organic Farming } \\
\text { Approval Agency }\end{array}$} & \multirow[t]{2}{*}{ Target Pests } & \multirow[t]{2}{*}{ Formulation $^{4}$} & \multicolumn{6}{|c|}{ Product Claims for Use ${ }^{5}$} \\
\hline & & & & & & & & $\mathbf{F}$ & STIM & FERT/ & ISR & DEC & OTHER \\
\hline Lettucemate & $\begin{array}{c}\text { Agrimm } \\
\text { Technologies } \\
\text { Limited (http://www. } \\
\text { tricho.com/) }\end{array}$ & $\begin{array}{c}\text { New } \\
\text { Zealand }\end{array}$ & T. hamatum & $\begin{array}{c}\text { Available } \\
\text { for use }\end{array}$ & $\begin{array}{c}\text { Nursery, lettuce; Rootzone } \\
\text { seedling inoculant, } \\
\text { stimulates root growth }\end{array}$ & & Flake, WP & & ST & & & & \\
\hline $\begin{array}{c}\text { Nemesis/Antago } \\
\text { nizer }\end{array}$ & Metcalf Biologicals & Australia & $\begin{array}{l}\text { T. harzianum } \\
\text { td } 81 \mathrm{~b}\end{array}$ & $\begin{array}{c}\text { Available } \\
\text { for use }\end{array}$ & $\begin{array}{c}\text { Bio-inoculant; late season } \\
\text { Botrytis in grapes and also } \\
\text { Brown rot in Stone fruit }\end{array}$ & & WP & $\mathrm{F}$ & & & & & \\
\hline $\begin{array}{l}\text { Nutri-Life } \\
\text { Platform }\end{array}$ & $\begin{array}{c}\text { Nutri-Tech Solutions } \\
\text { (http://www.nutri- } \\
\text { tech.com.au) }\end{array}$ & Australia & $\begin{array}{l}\text { T. lignorum } \\
\text { included, } \\
\text { mycorrhize }\end{array}$ & $\begin{array}{l}\text { Available } \\
\text { for use }\end{array}$ & $\begin{array}{c}\text { Builds humus, improved } \\
\text { nutrient uptake, boosts } \\
\text { phosphate and zinc } \\
\text { availability, nitrogen } \\
\text { fixation }\end{array}$ & & Liquid & & & FERT & & DEC & \\
\hline $\begin{array}{c}\text { Nutri-Life } \\
\text { TrichoShield }\end{array}$ & $\mid \begin{array}{c}\text { Nutri-Tech Solutions } \\
\text { (http://www.nutri- } \\
\text { tech.com.au) }\end{array}$ & Australia & $\begin{array}{l}\text { T. harzianum, } \\
\text { T. lignorum, } \\
\text { T. koningii }\end{array}$ & $\begin{array}{l}\text { Available } \\
\text { for use }\end{array}$ & $\begin{array}{c}\text { Root-zone balance is } \\
\text { coupled with plant growth } \\
\text { promotion, applied to } \\
\text { seeds, transplants, bulbs, } \\
\text { cuttings, grafts and } \\
\text { established crops }\end{array}$ & & Liquid & & ST & FERT & & & \\
\hline Solstice & Metcalf Biologicals & Australia & $\begin{array}{c}\text { Trichoderma } \\
\text { Td } 82 \text { and } \mathrm{Td} 84\end{array}$ & $R$ & $\begin{array}{l}\text { Reduce the level of } \\
\text { infection of raspberry } \\
\text { canes by Phytophthora }\end{array}$ & & & $\mathrm{F}$ & & & & & \\
\hline Tenet & \begin{tabular}{|c|} 
Agrimm \\
Technologies \\
Limited (http://www. \\
tricho.com/)
\end{tabular} & $\begin{array}{c}\text { New } \\
\text { Zealand }\end{array}$ & $\begin{array}{l}\text { T. atroviride } \\
\text { LC52 }\end{array}$ & $R$ & $\begin{array}{c}\text { Biofungicide applied } \\
\text { during field planting of } \\
\text { onions and garlic, } \\
\text { protection from pathogens, } \\
\text { improving plant emergence } \\
\text { and establishment }\end{array}$ & $\begin{array}{c}\text { Control of onion white } \\
\text { rot and reduction of } \\
\text { Fusarium basal rot }\end{array}$ & Granules & $\mathrm{F}$ & ST & & & & \\
\hline Tenet WP & Isagro USA & Australia & $\begin{array}{l}\text { T. asperellum } \\
\text { strain ICC } 012\end{array}$ & $\begin{array}{c}\text { Availabe for } \\
\text { use }\end{array}$ & & & & $\mathrm{F}$ & & & & & \\
\hline TRIANUM-G & $\begin{array}{c}\text { Koppert B.V. } \\
\text { (http://www.koppert. } \\
\text { com/diseases/overvie } \\
\text { w/) }\end{array}$ & $\begin{array}{l}\text { EU, New } \\
\text { Zealand, } \\
\text { Australia }\end{array}$ & $\begin{array}{c}\text { T. harzianum } \\
\text { strain T-22 (Item } \\
108)\end{array}$ & R, Annex I & \begin{tabular}{|c|} 
Turf- greens. Increases \\
resistance of plants to \\
stress caused by diseases, \\
sub-optimal feeding and \\
watering. For use in the \\
cultivation of vegetables, \\
soft fruit, herbs, bulbs,
\end{tabular} & & Granules & $\mathrm{F}$ & ST & FERT & ISR & & \\
\hline
\end{tabular}


Appendix 1. contd...

\begin{tabular}{|c|c|c|c|c|c|c|c|c|c|c|c|c|c|}
\hline \multirow[t]{2}{*}{ Product Name } & \multirow[t]{2}{*}{$\begin{array}{c}\text { Company/Distribut } \\
\text { or (website) }\end{array}$} & \multirow[t]{2}{*}{ Country $^{1}$} & \multirow{2}{*}{$\begin{array}{c}\text { Active } \\
\text { Substances } \\
\begin{array}{c}\text { Trichoderma, } \\
\text { Gliocladium } \\
\text { spp. }\end{array}\end{array}$} & \multirow[t]{2}{*}{ Registered $^{2}$} & \multirow{2}{*}{$\begin{array}{c}\text { Target Uses, Label } \\
\text { Claims, Recommended } \\
\text { Crops, Organic Farming } \\
\text { Approval Agency }^{3}\end{array}$} & \multirow[t]{2}{*}{ Target Pests } & \multirow[t]{2}{*}{ Formulation $^{4}$} & \multicolumn{6}{|c|}{ Product Claims for Use $^{5}$} \\
\hline & & & & & & & & $\mathbf{F}$ & STIM & $\begin{array}{l}\text { FERT/ } \\
\text { NUTR }\end{array}$ & ISR & DEC & OTHER \\
\hline & & & & & $\begin{array}{c}\text { ornamentals, perennials, } \\
\text { turf and arboriculture (both } \\
\text { protected and open field), } \\
\text { regimes or climatic } \\
\text { conditions, and increases } \\
\text { nutrient uptake; enhanced } \\
\text { growth and development } \\
\text { of roots and above-ground } \\
\text { plant parts. }\end{array}$ & & & & & & & & \\
\hline TRIANUM-P & $\begin{array}{c}\text { Koppert B.V. } \\
\text { (http://www.koppert. } \\
\text { com/diseases/overvie } \\
\text { w/) }\end{array}$ & $\begin{array}{l}\text { EU, New } \\
\text { Zealand, } \\
\text { Australia }\end{array}$ & $\begin{array}{c}\text { T. harzianum } \\
\text { strain T-22 (Item } \\
108)\end{array}$ & R, Annex I & \begin{tabular}{|c|} 
Tomato, Turf- greens. \\
Increases resistance of \\
plants to stress caused by \\
diseases, sub-optimal \\
feeding and watering. For \\
use in the cultivation of \\
vegetables, soft fruit, \\
herbs, bulbs, ornamentals, \\
perennials, turf and \\
arboriculture (both \\
protected and open field), \\
regimes or climatic \\
conditions, and increases \\
nutrient uptake; enhanced \\
growth and development \\
of roots and above-ground \\
plant parts.
\end{tabular} & $\begin{array}{c}\text { Rhizoctonia spp., } \\
\text { Fusarium sp., Pythium } \\
\text { sp. }\end{array}$ & $\begin{array}{c}\text { WP, drench, } \\
\text { irrigation - } \\
\text { propagation, } \\
\text { sowing, } \\
\text { transplant }\end{array}$ & $\mathrm{F}$ & ST & FERT & ISR & & \\
\hline Trich-A-Soil & $\begin{array}{c}\text { Organic Crop } \\
\text { Protectants } \\
\text { (http://www.ocp.com } \\
\text { au/products.aspx?id } \\
=25 \text { ) }\end{array}$ & Australia & T. viride & $\begin{array}{c}\text { Available } \\
\text { for use }\end{array}$ & \begin{tabular}{|c} 
Bio-inoculant; growth \\
effects on plants in the \\
presence of diseases like \\
Pythium and Rhizoctonia \\
in horticultural crops, \\
hydroponics and \\
profesional turf
\end{tabular} & & & $\mathrm{F}$ & ST & & & & \\
\hline Trichodex & \begin{tabular}{c|} 
Makhteshim \\
Chemical Works Ltd.
\end{tabular} & $\begin{array}{l}\text { South } \\
\text { Africa, } \\
\text { Australia, } \\
\text { USA } \\
\text { (Cancelled } \\
\text { 2004) }\end{array}$ & \begin{tabular}{|c|} 
T. harzianum \\
Rifai strain T-39 \\
(IMI 206039)
\end{tabular} & $\mathrm{R}$ & & $\begin{array}{c}\text { Botrytis cinerea, } \\
\text { Collectotrichum spp., } \\
\text { Fulvia fulva, Monilia } \\
\text { laxa, Plasmopara } \\
\text { viticola, } \\
\text { Pseudoperonospora } \\
\text { cubensis, Rhizopus } \\
\text { stolonifera, Sclerotinia } \\
\text { sclerotiorum }\end{array}$ & & $\mathrm{F}$ & & & & & \\
\hline $\begin{array}{l}\text { Trichodry, } \\
\text { Trichoflow }\end{array}$ & \begin{tabular}{|c|} 
Agrimm \\
Technologies \\
Limited (http://www. \\
tricho.com/)
\end{tabular} & $\begin{array}{l}\text { New } \\
\text { Zealand }\end{array}$ & $\begin{array}{l}\text { T. atroviride } \\
\text { LC52 }\end{array}$ & $\mathrm{R}$ & $\begin{array}{c}\text { Nursery bio- } \\
\text { inoculant/fertilizer, } \\
\text { distribution in the root } \\
\text { zone for establishment }\end{array}$ & & $\begin{array}{c}\text { Flake, WP, } \\
\text { dry } \\
\text { incorporation, } \\
\text { drench }\end{array}$ & & & FERT & & & \\
\hline
\end{tabular}


Appendix 1. contd...

\begin{tabular}{|c|c|c|c|c|c|c|c|c|c|c|c|c|c|}
\hline \multirow[t]{2}{*}{ Product Name } & \multirow{2}{*}{$\begin{array}{c}\text { Company/Distribut } \\
\text { or (website) }\end{array}$} & \multirow[t]{2}{*}{ Country $^{1}$} & \multirow{2}{*}{$\begin{array}{c}\text { Active } \\
\text { Substances } \\
\begin{array}{c}\text { Trichoderma, } \\
\text { Gliocladium } \\
\text { spp. }\end{array}\end{array}$} & \multirow[t]{2}{*}{ Registered $^{2}$} & \multirow{2}{*}{$\begin{array}{c}\text { Target Uses, Label } \\
\text { Claims, Recommended } \\
\text { Crops, Organic Farming } \\
\text { Approval Agency }^{3}\end{array}$} & \multirow[t]{2}{*}{ Target Pests } & \multirow[t]{2}{*}{ Formulation $^{4}$} & \multicolumn{6}{|c|}{ Product Claims for Use ${ }^{5}$} \\
\hline & & & & & & & & $\mathbf{F}$ & STIM & $\begin{array}{l}\text { FERT/ } \\
\text { NUTR }\end{array}$ & ISR & DEC & OTHER \\
\hline Trichopel & \begin{tabular}{|c|} 
Agrimm \\
Technologies \\
Limited (http://www. \\
tricho.com/)
\end{tabular} & $\begin{array}{c}\text { New } \\
\text { Zealand }\end{array}$ & $\begin{array}{l}\text { T. atroviride } \\
\text { LC52 }\end{array}$ & $\mathrm{R}$ & $\begin{array}{c}\text { Nursery and field bio- } \\
\text { inoculant/fertilizer; } \\
\text { orchards and vineyards; } \\
\text { Root zone starter granule, } \\
\text { nutrient start-up and } \\
\text { sustainability }\end{array}$ & & Granules & & & FERT & & & \\
\hline Trichospray & \begin{tabular}{|c|} 
Agrimm \\
Technologies \\
Limited (http://www. \\
tricho.com/)
\end{tabular} & $\begin{array}{l}\text { New } \\
\text { Zealand }\end{array}$ & $\begin{array}{l}\text { T. atroviride } \\
\text { LC52 }\end{array}$ & $\mathrm{R}$ & \begin{tabular}{|c|} 
Nursery bio- \\
inoculant/fertilizer, foliar \\
spray distribution on \\
foliage and flowers for \\
establishment and growth
\end{tabular} & & WP & & & FERT & & & \\
\hline Unite WP & \begin{tabular}{|c|} 
Agrimm \\
Technologies \\
Limited (http://www. \\
tricho.com/)
\end{tabular} & $\begin{array}{l}\text { Australia, } \\
\text { New } \\
\text { Zealand }\end{array}$ & T. harzianum & $R$ & $\begin{array}{c}\text { Rootzone Drench - } \\
\text { Registered for Control of } \\
\text { damping off and root rot }\end{array}$ & $\begin{array}{c}\text { Barrier against } \\
\text { damping off and root } \\
\text { rots while boosting the } \\
\text { resilience and strength } \\
\text { of the plant's own } \\
\text { immune system }\end{array}$ & WP & $\mathrm{F}$ & & & ISR & & \\
\hline $\begin{array}{c}\text { Vinevax } \\
\text { Biodowel }\end{array}$ & \begin{tabular}{|c|} 
Agrimm \\
Technologies \\
Limited (http://www. \\
tricho.com/)
\end{tabular} & $\begin{array}{c}\text { New } \\
\text { Zealand, } \\
\text { Australia }\end{array}$ & $\begin{array}{l}\text { T. atroviride } \\
\text { LC52 }\end{array}$ & $\mathrm{R}$ & \begin{tabular}{|c|} 
Natural "vaccination" \\
treatment lasting $4-5$ years \\
protecting orchard, \\
ornamental trees and \\
grapevines against many \\
wood-infecting fungi \\
causing trunk and root \\
diseases. Improves crop \\
productivity by stimulating \\
a systemic protective \\
response to plant stress
\end{tabular} & Eutypa dieback & $\begin{array}{c}\text { Solid (wood } \\
\text { dowels) }\end{array}$ & $\mathrm{F}$ & ST & & ISR & & \\
\hline $\begin{array}{c}\text { VINEVAX }^{\mathrm{TM}} \\
\text { Bio-injection } \\
\text { (formerly } \\
\text { Trichoject) }\end{array}$ & \begin{tabular}{|c|} 
Agrimm \\
Technologies \\
Limited (http://www. \\
tricho.com/)
\end{tabular} & $\begin{array}{c}\text { New } \\
\text { Zealand, } \\
\text { Australia }\end{array}$ & $\begin{array}{l}\text { T. atroviride } \\
\text { LC52 }\end{array}$ & $\mathrm{R}$ & $\begin{array}{c}\text { Liquid injection plant } \\
\text { defence booster. Protects } \\
\text { kiwifruit vines against } \\
\text { Armillaria root rot; } \\
\text { orchard and ornamental } \\
\text { trees against wood and root } \\
\text { decay fungi }\end{array}$ & Eutypa dieback & WP & $\mathrm{F}$ & ST & & ISR & & \\
\hline $\begin{array}{c}\text { VINEVAX }^{\mathrm{TM}} \\
\text { Pruning Wound } \\
\text { Dressing }\end{array}$ & \begin{tabular}{|c|} 
Agrimm \\
Technologies \\
Limited (http://www. \\
tricho.com/)
\end{tabular} & $\begin{array}{c}\text { New } \\
\text { Zealand, } \\
\text { Australia }\end{array}$ & $\begin{array}{l}\text { T. atroviride } \\
\text { LC52 }\end{array}$ & $\mathrm{R}$ & $\begin{array}{c}\text { Living barrier treatment } \\
\text { for pruning wounds. } \\
\text { Protects orchard trees } \\
\text { against many wood decay } \\
\text { fungi including silver leaf } \\
\text { and grapevines against } \\
\text { dieback, dead arm and vine } \\
\text { decline diseases }\end{array}$ & Eutypa dieback & WP & $\mathrm{F}$ & ST & & ISR & & \\
\hline
\end{tabular}


Appendix 1. contd...

\begin{tabular}{|c|c|c|c|c|c|c|c|c|c|c|c|c|c|}
\hline \multirow[t]{2}{*}{ Product Name } & \multirow[t]{2}{*}{$\begin{array}{c}\text { Company/Distribut } \\
\text { or (website) }\end{array}$} & \multirow[t]{2}{*}{ Country $^{1}$} & $\begin{array}{c}\text { Active } \\
\text { Substances }\end{array}$ & Registered $^{2}$ & $\begin{array}{c}\text { Target Uses, Label } \\
\text { Claims, Recommended } \\
\text { Crops, Organic Farming }\end{array}$ & Target Pests & Formulation $^{4}$ & \multicolumn{6}{|c|}{ Product Claims for Use $^{5}$} \\
\hline & & & $\begin{array}{l}\text { Trichoderma, } \\
\text { Gliocladium } \\
\text { spp. }\end{array}$ & & & & & $\mathbf{F}$ & STIM & $\begin{array}{l}\text { FERT/ } \\
\text { NUTR }\end{array}$ & ISR & DEC & OTHI \\
\hline
\end{tabular}

Multiple Worldwide Zones

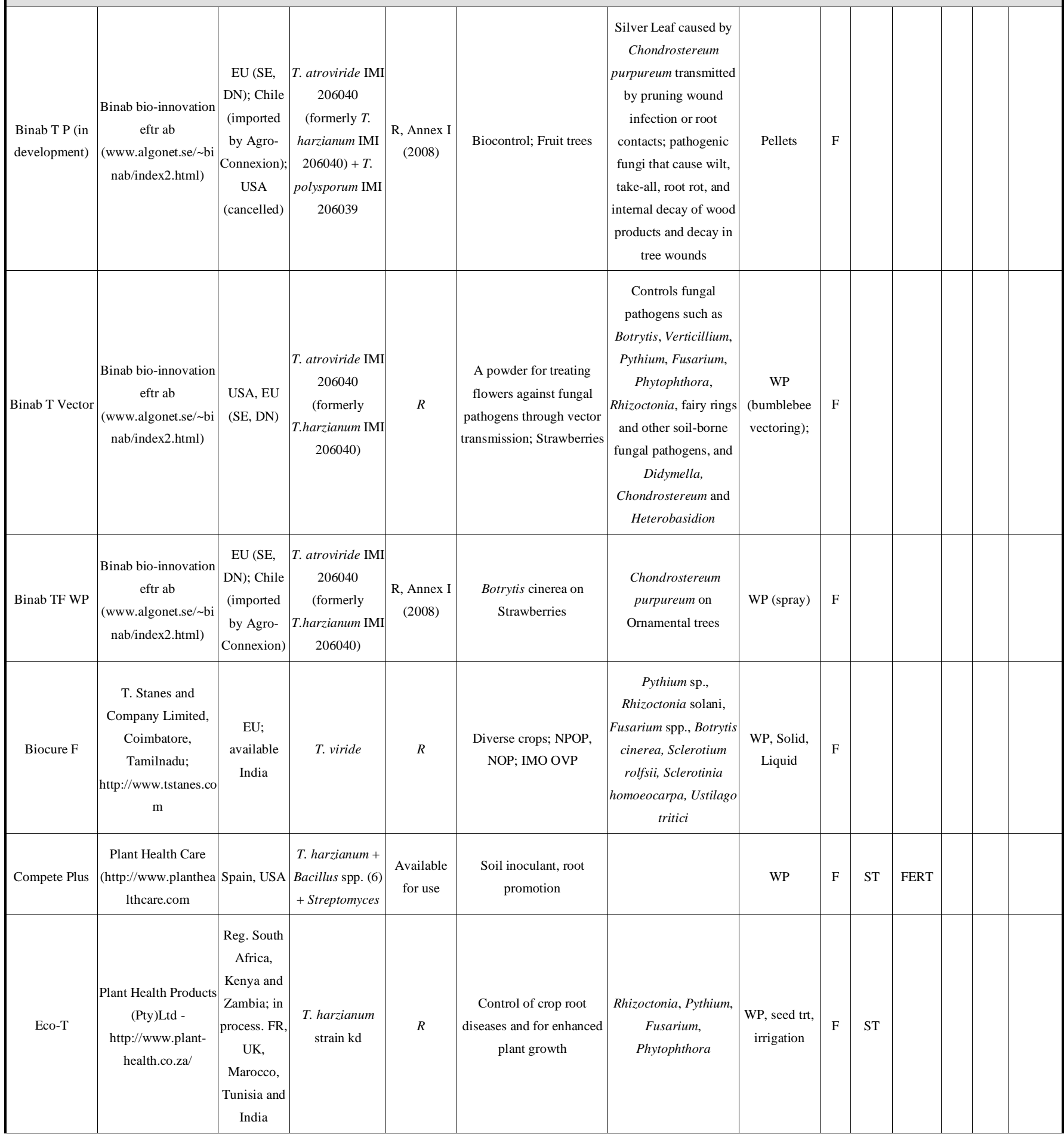


Appendix 1. contd...

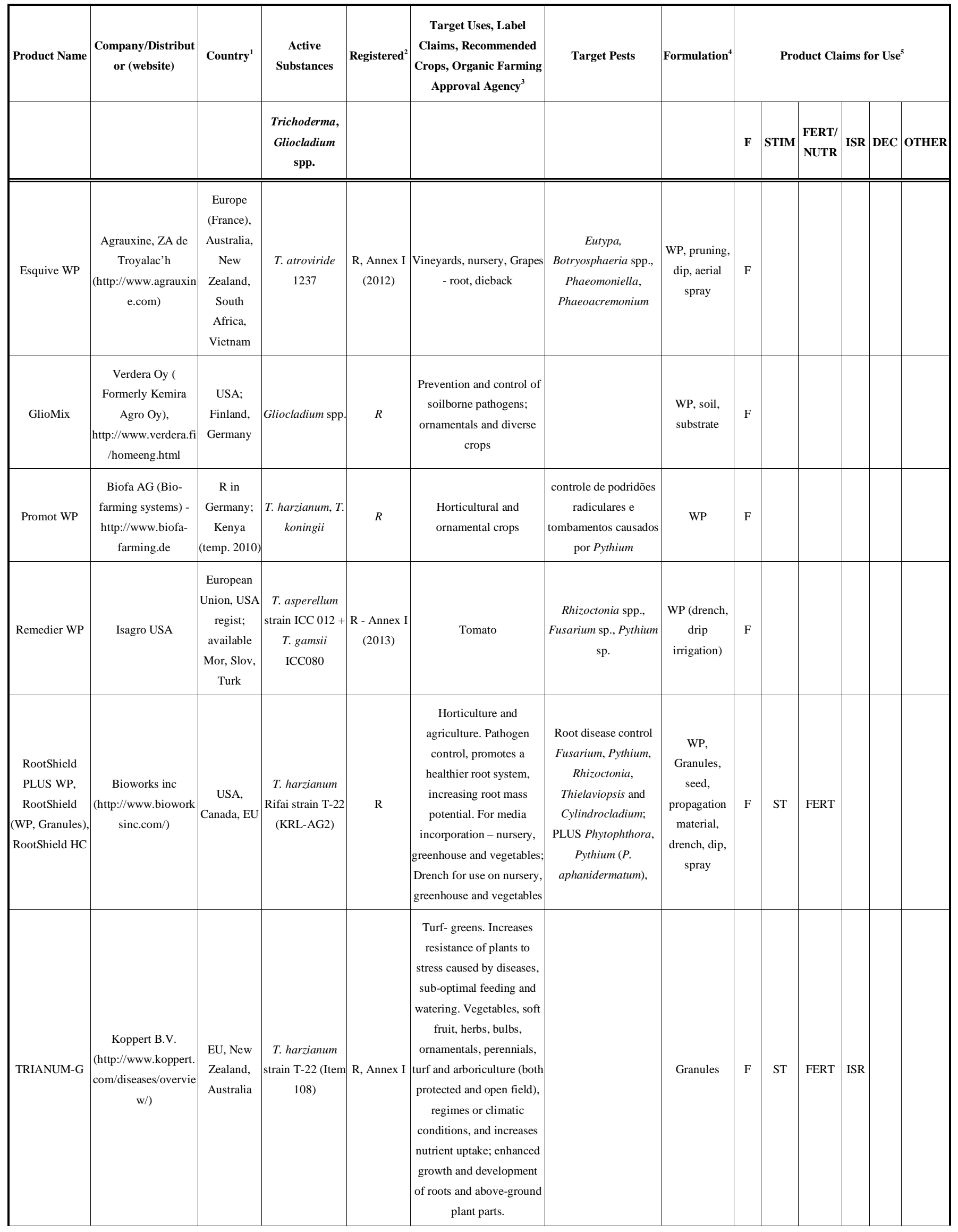


Appendix 1. contd...

\begin{tabular}{|c|c|c|c|c|c|c|c|c|c|c|c|c|c|}
\hline \multirow[t]{2}{*}{ Product Name } & \multirow[t]{2}{*}{$\begin{array}{c}\text { Company/Distribut } \\
\text { or (website) }\end{array}$} & \multirow[t]{2}{*}{ Country $^{1}$} & \multirow{2}{*}{\begin{tabular}{|c|} 
Active \\
Substances
\end{tabular}} & \multirow[t]{2}{*}{ Registered $^{2}$} & \multirow{2}{*}{$\begin{array}{c}\text { Target Uses, Label } \\
\text { Claims, Recommended } \\
\text { Crops, Organic Farming } \\
\text { Approval Agency }^{3}\end{array}$} & \multirow[t]{2}{*}{ Target Pests } & \multirow[t]{2}{*}{ Formulation $^{4}$} & \multicolumn{6}{|c|}{ Product Claims for Use $^{5}$} \\
\hline & & & & & & & & $\mathbf{F}$ & STIM & $\begin{array}{l}\text { FERT/ } \\
\text { NUTR }\end{array}$ & ISR & DEC & OTHER \\
\hline Trichodex & $\begin{array}{c}\text { Makhteshim } \\
\text { Chemical Works Ltd. }\end{array}$ & \begin{tabular}{|c} 
South \\
Africa, \\
Australia, \\
USA \\
(Cancelled \\
2004)
\end{tabular} & $\begin{array}{c}\text { T. harzianum } \\
\text { Rifai strain T-39 } \\
\text { (IMI 206039) }\end{array}$ & $\mathrm{R}$ & & \begin{tabular}{|} 
Botrytis cinerea, \\
Collectotrichum spp., \\
Fulvia fulva, Monilia \\
laxa, Plasmopara \\
viticola, \\
Pseudoperonospora \\
cubensis, Rhizopus \\
stolonifera, Sclerotinia \\
sclerotiorum
\end{tabular} & & $\mathrm{F}$ & & & & & \\
\hline VIRISAN & Isagro USA & \begin{tabular}{|c} 
European \\
Union, USA \\
regist; \\
available \\
Mor, Slov, \\
Turk
\end{tabular} & $\begin{array}{l}\text { T. asperellum } \\
\quad \text { TV1 }\end{array}$ & $\left|\begin{array}{c}\text { R - Annex I } \\
(2013)\end{array}\right|$ & Tomato & $\begin{array}{c}\text { Rhizoctonia spp., } \\
\text { Fusarium sp., Pythium } \\
\text { sp. }\end{array}$ & $\begin{array}{c}\text { WP, drench, } \\
\text { drip irrigation }\end{array}$ & $\mathrm{F}$ & & & & & \\
\hline
\end{tabular}

Note: This list is not considered to be complete; any omissions or errors are regretted. Furthermore, indications to commercial products by the authors does not in anyway signify an endorsement of the product or manufacturer/distributor.

${ }^{1}$ Country - where product is commercially marketed

${ }^{2}$ Registration: $\mathbf{R}$ - registered for use by authorized agency anywhere in the world; $\mathbf{R}$, Annex I (date) - registered for use by the European Commission; active product included in Annex I list (date of approval); $R$ - putative registered product, sources not confirmed; Available for use - distributed on the commercial market, not registered

${ }^{3}$ Organic Farming Agencies: IMO OVP (Institute for Marketecology - Off farm input Verification Procedure) approved list of inputs and manufacturers, IMO India, 20130325; EU Organic according/equivalent to EU Reg (EC) 834/2007 and 889/2008 (http://www.imo.ch/logicio/pmws/indexDOM.php?client_id=imo\&page_id=home\&lang iso639=en); JAS (Japanese Agricultural Standard); NOP (US National Organic Program NOP); NPOP (National Program for Organic production NPOP); ORMI - Organic Materials Review Institute ${ }^{4}$ Formulations: WP - wettable powder; Gran - Granules; Liq - Liquid; Pell - Pellets; Solid - Rice, dowels, coco, soil

${ }^{5}$ Product claims: F - Fungicide, fungal pathogen control, preventative, curative; ST - Stimulant, growth promoter/enhancer of roots, plant or yield; FERT - Fertilizer, or improved nutrient availability, uptake, solubilization; ISR - Induced Resistance to pathogens and/or abiotic stresses; DEC- Decomposer; NEM - nematocide; INS - Insecticide

\section{REFERENCES}

Eurostat TEC. The use of plant protection products in the European Union Data 1992-2003 2007. Available from: http:
//epp.eurostat.ec.europa.eu/cache/ITY OFFPUB/KS-76-06669/EN/KS-76-06-669-EN.PDF

[2] The Bio-Pesticides Database (BPDB) developed by the Agriculture \& Environment Research Unit (AERU), University of 
Hertfordshire, 2011. [database on the Internet]. Available from: http: //sitem.herts.ac.uk/aeru/bpdb/index.htm

[3] European Commission. EU pesticides database of active substances, Regulation (EC) No 1107/2009 2009; Available from: http: //ec.europa.eu/sanco_pesticides/public/index.cfm?event=activesubstance.detail

[4] Benitez T, Rincon AM, Limon MC, Codon AC. Biocontrol mechanisms of Trichoderma strains. Int Microbiol 2004; 7(4): 24960.

[5] Hermosa R, Viterbo A, Chet I, Monte E. Plant-beneficial effects of Trichoderma and of its genes. Microbiology 2012; 158(1): 17-25.

[6] Druzhinina IS, Seidl-Seiboth V, Herrera-Estrella A, et al. Trichoderma: the genomics of opportunistic success. Nat Rev Micro 2011; 9(10): 749-59.

[7] Lorito M, Woo SL, Harman, Gary E, Monte E. Translational research on Trichoderma: from 'Omics to the field'. Annu Rev Phytopathol 2010; 48(1): 395-417.

[8] Mukherjee PK, Horwitz BA, Herrera-Estrella A, Schmoll M, Kenerley CM. Trichoderma research in the genome era. Annu Rev Phytopathol 2013; 51: 105-29.

[9] Woo SL, Scala F, Ruocco M, Lorito M. The molecular biology of the interactions between Trichoderma spp., phytopathogenic fungi, and plants. Phytopathology 2006; 96(2): 181-5.

[10] Brunner K, Zeilinger S, Ciliento R, et al. Improvement of the fungal biocontrol agent Trichoderma atroviride to enhance both antagonism and induction of plant systemic disease resistance. Appl Environ Microb 2005; 71(7): 3959-65.

[11] Donzelli BGG, Lorito M, Scala F, Harman GE. Cloning, sequence and structure of a gene encoding an antifungal glucan 1,3-betaglucosidase from Trichoderma atroviride (T-harzianum). Gene 2001; 277(1-2): 199-208.

[12] Zeilinger S, Galhaup C, Payer K, et al. Chitinase gene expression during mycoparasitic interaction of Trichoderma harzianum with its host. Fungal Genet Biol 1999; 26(2): 131-40.

[13] Hermosa R, Belén RM, Cardoza RE, Nicolás C, Monte E, Gutierrez S. The contribution of Trichoderma to balancing the costs of plant growth and defense. Int Microbiol 2013; 16(2): 6980.

[14] Atanasova L, Crom SL, Gruber S, et al. Comparative transcriptomics reveals different strategies of Trichoderma mycoparasitism. BMC Genomics 2013; 14(1): 121.

[15] Sempere F, Santamarina MP. Antagonistic interactions between fungal rice pathogen Fusarium verticillioides (Sacc.) Nirenberg and Trichoderma harzianum Rifai. Ann Microbiol. 2009; 59(2): 25966.

[16] Vinale F, Marra R, Scala F, Ghisalberti EL, Lorito M, Sivasithamparam K. Major secondary metabolites produced by two commercial Trichoderma strains active against different phytopathogens. Lett Appl Microbiol 2006; 43(2): 143-8.

[17] Mukherjee M, Horwitz BA, Sherkhane PD, Hadar R, Mukherjee PK. A secondary metabolite biosynthesis cluster in Trichoderma virens: evidence from analysis of genes underexpressed in a mutant defective in morphogenesis and antibiotic production. Curr Genet 2006; 50(3): 193-202.

[18] Hanhong B. Trichoderma species as abiotic and biotic Stress quenchers in plants. Res J Biotechnol 2011; 6(3): 73-9.

[19] Mukherjee PK, Horwitz BA, Kenerley CM. Secondary metabolism in Trichoderma - a genomic perspective. Microbiology 2012; 158(1): 35-45.

[20] Trabelsi D, Mhamdi R. Microbial inoculants and their impact on soil microbial communities: a review. Biomed Res Int 2013; 2013: 863240 .

[21] Tucci M, Ruocco M, De Masi L, De Palma M, Lorito M. The beneficial effect of Trichoderma spp. on tomato is modulated by the plant genotype. Mol Plant Pathol 2011; 12(4): 341-54.

[22] Vinale F, Sivasithamparam K, Ghisalberti EL, Ruocco M, Wood S, Lorito M. Trichoderma secondary metabolites that affect plant metabolism. Nat Prod Commun 2012; 7(11): 1545-50.

[23] Fontenelle ADB, Guzzo SD, Lucon CMM, Harakava R. Growth promotion and induction of resistance in tomato plant against Xanthomonas euvesicatoria and Alternaria solani by Trichoderma spp. Crop Prot 2011; 30(11): 1492-500.
[24] Alizadeh H, Behboudi K, Ahmadzadeh M, et al. Induced systemic resistance in cucumber and Arabidopsis thaliana by the combination of Trichoderma harzianum Tr6 and Pseudomonas sp. Ps14. Biol Control 2013; 65(1): 14-23.

[25] Rawat L, Singh Y, Shukla N, Kumar J. Seed biopriming with salinity tolerant isolates of Trichoderma harzianum alleviates salt stress in rice: growth, physiological and biochemical characteristics. J Plant Pathol 2012; 94(2): 353-65.

[26] Bae H, Sicher RC, Kim MS, et al. The beneficial endophyte Trichoderma hamatum isolate DIS $219 \mathrm{~b}$ promotes growth and delays the onset of the drought response in Theobroma cacao. J Exp Bot 2009; 60(11): 3279-95.

[27] Harman GE, Howell CR, Viterbo A, Chet I, Lorito M. Trichoderma species--opportunistic, avirulent plant symbionts. Nat Rev Microbiol 2004; 2(1): 43-56.

[28] Vinale F, Sivasithamparam K, Ghisalberti EL, et al. A novel role for Trichoderma secondary metabolites in the interactions with plants. Physiol Mole Plant Pathol 2008; 72(1-3): 80-6.

[29] Berg G. Plant-microbe interactions promoting plant growth and health: perspectives for controlled use of microorganisms in agriculture. Appl Microbiol Biot 2009; 84(1): 11-8.

[30] PAN Pesticide Database [database on the Internet] 2010. Available from: http: //www.pesticideinfo.org

[31] Kubicek CP, Harman GE, editors. Trichoderma and Gliocladium. Volume 1, Basic biology, taxonomy and genetics. London, UK: Taylor \& Francis Ltd 1998.

[32] Brotman Y, Briff E, Viterbo A, Chet I. Role of swollenin, an expansin-like protein from Trichoderma, in plant root colonization. Plant Physiol 2008; 147(2): 779-89.

[33] Hermosa R, Viterbo A, Chet I, Monte E. Plant-beneficial effects of Trichoderma and of its genes. Microbiology 2012; 158(Pt 1): 1725.

[34] Shoresh M, Yedidia I, Chet I. Involvement of jasmonic acid/ethylene signaling pathway in the systemic resistance induced in cucumber by Trichoderma asperellum T203. Phytopathology 2005; 95(1): 76-84.

[35] Korolev N, David DR, Elad Y. The role of phytohormones in basal resistance and Trichoderma-induced systemic resistance to Botrytis cinerea in Arabidopsis thaliana. Biocontrol 2008; 53(4): 667-83.

[36] Alfano G, Ivey MLL, Cakir C, et al. Systemic modulation of gene expression in tomato by Trichoderma hamatum 382. Phytopathology 2007; 97(4): 429-37.

[37] Vinale F, Marra R, Scala F, Ghisalberti EL, Lorito M, Sivasithamparam K. Major secondary metabolites produced by two commercial Trichoderma strains active against different phytopathogens. Lett Appl Microbiol 2006; 43(2): 143-8.

[38] Vinale F, Sivasithamparam K, Ghisalberti EL, Marra R, Woo SL, Lorito M. Trichoderma-plant-pathogen interactions. Soil Biol Biochem 2008; 40(1): 1-10.

[39] Harman GE. Overview of mechanisms and uses of Trichoderma spp. Phytopathology 2006; 96(2): 190-4.

[40] Perazzolli M, Dagostin S, Ferrari A, Elad Y, Pertot I. Induction of systemic resistance against Plasmopara viticola in grapevine by Trichoderma harzianum $\mathrm{T} 39$ and benzothiadiazole. Biological Control 2008; 47(2): 228-34

[41] Harman GE, C.P. K, editors. Trichoderma and Gliocladium. Volume 2. Enzymes, biological control and commercial applications 1998 .

[42] Motta FL, Santana MHA. Biomass production from Trichoderma viride in nonconventional oat medium. Biotechnol Progr 2012; 28(5): 1245-50.

[43] Santos A, Garcia M, Cotes AM, Villamizar L. The effect of the formulation on the shelf-life of biopesticides based on two colombian isolates of Trichoderma koningiopsis Th003 and Trichoderma asperellum Th034. Rev Iberoam Micol 2012; 29(3): 150-6.

[44] de los Santos-Villalobos S, Hernandez-Rodriguez LE, VillasenorOrtega F, Pena-Cabriales JJ. Production of Trichoderma asperellum T8a spores by a "home made" solid-state fermentation of mango industrial wastes. Bioresources 2012; 7(4): 4938-51.

[45] Harman GE, Obregón MA, Samuels G, Lorito M. Changing models of biocontrol in the developing and developed world. Plant Dis 2010: Accepted for publication. 
[46] Rojo FG, Reynoso MM, Ferez M, Chulze SN, Torres AM. Biological control by Trichoderma species of Fusarium solani causing peanut brown root rot under field conditions. Crop Prot 2007; 26(4): 549-55.

[47] McLean KL, Hunt JS, Stewart A, Wite D, Porter IJ, Villalta O. Compatibility of a Trichoderma atroviride biocontrol agent with management practices of Allium crops. Crop Prot 2012; 33: 94100.

[48] Radwan MA, Farrag SAA, Abu-Elamayem MM, Ahmed NS. Biological control of the root-knot nematode, Meloidogyne incognita on tomato using bioproducts of microbial origin. Appl Soil Ecol 2012; 56: 58-62.

[49] Hassanein NM. Biopotential of some Trichoderma spp. against cotton root rot pathogens and profiles of some of their metabolites. Afr J Microbiol Res 2012; 6(23): 4878-90.

[50] Zancan WLA, Machado JD, de Sousa BFM, de Matos CDM. Mycelial growth, production and germination of sclerotia of sclerotinia sclerotiorum in the presence of fungicides and Trichoderma harzianum. Biosci J 2012; 28(5): 782-9.

[51] Howell CR. Understanding the mechanisms employed by Trichoderma virens to effect biological control of cotton diseases. Phytopathology 2006; 96(2): 178-80.

[52] Lorito M, Harman GE, Hayes CK, et al. Chitinolytic enzymes produced by Trichoderma-harzianum - antifungal activity of purified endochitinase and chitobiosidase. Phytopathology 1993; 83(3): 302-7.

[53] Dipietro A, Lorito M, Hayes CK, Broadway RM, Harman GE. Endochitinase from gliocladium-virens - isolation, characterization, and synergistic antifungal activity in combination with gliotoxin. Phytopathology 1993; 83(3): 308-13.

[54] Lorito M, Dipietro A, Hayes CK, Woo SL, Harman GE. Antifungal, synergistic interaction between chitinolytic enzymes from Trichoderma-harzianum and enterobacter-cloacae. Phytopathology 1993; 83(7): 721-8.

[55] Lorito M, Peterbauer TC, Hayes CK, Harman GE. Synergistic interaction between fungal cell-wall degrading enzymes and different antifungal compounds enhances inhibition of spore germination. Microbiol-Uk 1994; 140: 623-9.

[56] Schirmbock M, Lorito M, Wang YL, et al. Parallel formation and synergism of hydrolytic enzymes and peptaibol antibiotics, molecular mechanisms involved in the antagonistic action of Trichoderma-harzianum against phytopathogenic fungi. Appl Environ Microb 1994; 60(12): 4364-70.

[57] Harman GE, Herrera-Estrella AH, Horwitz BA, Lorito M. Special issue: Trichoderma - from basic biology to biotechnology. Microbiol-Sgm 2012; 158: 1-2.

[58] Liu M, Sun ZX, Zhu J, Xu T, Harman GE, Lorito M. Enhancing rice resistance to fungal pathogens by transformation with cell wall degrading enzyme genes from Trichoderma atroviride. J Zhejiang Univ Sci 2004; 5(2): 133-6.

[59] Kullnig C, Mach RL, Lorito M, Kubicek CP. Enzyme diffusion from Trichoderma atroviride (= T-harzianum $\mathrm{P} 1)$ to Rhizoctonia solani is a prerequisite for triggering of Trichoderma ech42 gene expression before mycoparasitic contact. Appl Environ Microb 2000; 66(5): 2232-4

[60] Moran-Diez E, Hermosa R, Ambrosino P, et al. The ThPG1 endopolygalacturonase is required for the Trichoderma harzianumplant beneficial interaction. Mol Plant Microbe In 2009; 22(8): $1021-31$

[61] Wharton PS, Kirk WW, Schafer RL, Tumbalam P. Evaluation of biological seed treatments in combination with management practices for the control of seed-borne late blight in potato. Biol Control 2012; 63(3): 326-32.

[62] Becker EM, Rajakulendran N, Shamoun SF. Trichoderma spp. antagonistic effects to $\mathrm{P}$ phytophthora ramorum growth and spore germination in vitro. Can J Plant Pathol-Revue Canadienne de Phytopathologie 2012; 34(2): 324-5.

[63] Di Pietro A, Lorito M, Hayes CK, Broadway RM, Harman GE. Endochitinase from Gliocladium-Virens - isolation, characterization, and synergistic antifungal activity in combination with gliotoxin. Phytopathology 1993; 83(3): 308-13.

[64] Shoresh M, Harman GE, Mastouri F. Induced systemic resistance and plant responses to fungal biocontrol agents. Annu Rev Phytopathol 2010; 48: 21-43.
[65] Qi WZ, Zhao L. Study of the siderophore-producing Trichoderma asperellum Q1 on cucumber growth promotion under salt stress. J Basic Microb 2013; 53(4): 355-64.

[66] Khan J, Ooka JJ, Miller SA, Madden LV, Hoitink HAJ. Systemic resistance induced by Trichoderma hamatum 382 in cucumber against Phytophthora crown rot and leaf blight. Plant Dis 2004; 88(3): 280-6.

[67] Nawrocka J, Małolepsza U. Diversity in plant systemic resistance induced by Trichoderma. Biol Control 2013; 67(2): 149-56.

[68] Morán-Diez E, Rubio B, Domínguez S, Hermosa R, Monte E, Nicolás C. Transcriptomic response of Arabidopsis thaliana after $24 \mathrm{~h}$ incubation with the biocontrol fungus Trichoderma harzianum. Journal of Plant Physiology 2012; 169(6): 614-20.

[69] Brotman Y, Landau U, Cuadros-Inostroza Á, et al. Trichodermaplant root colonization: escaping early plant defense responses and activation of the antioxidant machinery for saline stress tolerance. Plos Pathog 2013; 9(3): e1003221. [doi: 10.1371/journal.ppat.1003221]

[70] Woo SL, Scala F, Ruocco M, Lorito M. The molecular biology of the interactions between Trichoderma spp., phytopathogenic fungi, and plants. Phytopathology 2006; 96(2): 181-5.

[71] Sundaramoorthy S, Raguchander T, Ragupathi N, Samiyappan R. Combinatorial effect of endophytic and plant growth promoting rhizobacteria against wilt disease of Capsicum annum L. caused by Fusarium solani. Biol Control 2012; 60(1): 59-67.

[72] Beneduzi A, Ambrosini A, Passaglia LMP. Plant growth-promoting rhizobacteria (PGPR): their potential as antagonists and biocontrol agents. Genet Mol Biol 2012; 35(4): 1044-51.

[73] Niu DD, Wang CJ, Guo YH, et al. The plant growth-promoting rhizobacterium Bacillus cereus AR156 induces resistance in tomato with induction and priming of defence response. Biocontrol Sci Techn 2012; 22(9): 991-1004.

[74] Weller DM, Mavrodi DV, van Pelt JA, Pieterse CMJ, van Loon LC, Bakker PAHM. Induced Systemic Resistance in Arabidopsis thaliana Against Pseudomonas syringae pv. tomato by 2,4 Diacetylphloroglucinol-Producing Pseudomonas fluorescens. Phytopathology 2012; 102(4): 403-12.

[75] Hahm MS, Sumayo M, Hwang YJ, et al. Biological control and plant growth promoting capacity of rhizobacteria on pepper under greenhouse and field conditions. J Microbiol 2012; 50(3): 380-5.

[76] Harman GE, Petzoldt R, Comis A, Chen J. Interactions Between Trichoderma harzianum Strain T22 and Maize Inbred Line Mo17 and Effects of These Interactions on Diseases Caused by Pythium ultimum and Colletotrichum graminicola. Phytopathology 2004; 94(2): 147-53.

[77] Studholme DJ, Harris B, Le Cocq K, et al. Investigating the beneficial traits of Trichoderma hamatum GD12 for sustainable agriculture - insights from genomics. Front Plant Sci [Original Research] 2013; 4: 258.

[78] Vinale F, Flematti G, Sivasithamparam K, et al. Harzianic acid, an antifungal and plant growth promoting metabolite from Trichoderma harzianum. J Nat Prod 2009; 72(11): 2032-5.

[79] Vinale F, Nigro M, Sivasithamparam K, et al. Harzianic acid: a novel siderophore from Trichoderma harzianum. FEMS Microbiol Lett 2013; 347(2): 123-9.

[80] Altomare C, Norvell WA, Bjorkman T, Harman GE. Solubilization of phosphates and micronutrients by the plant-growth-promoting and biocontrol fungus Trichoderma harzianum Rifai 1295-22. Appl Environ Microb 1999; 65(7): 2926-33.

[81] Zhang F, Yuan J, Yang X, et al. Putative Trichoderma harzianum mutant promotes cucumber growth by enhanced production of indole acetic acid and plant colonization. Plant Soil 2013; 368(1-2): 433-44.

[82] Rubio MB, Hermosa R, Reino JL, Collado IG, Monte E. Thetf1 transcription factor of Trichoderma harzianum is involved in 6pentyl-2H-pyran-2-one production and antifungal activity. Fungal Genet Biol 2009; 46(1): 17-27.

[83] Vinale F, Ghisalberti EL, Flematti G, Marra R, Lorito M, Sivasithamparam K. Secondary metabolites produced by a rootinhabiting sterile fungus antagonistic towards pathogenic fungi. Lett Appl Microbiol 2010; 50(4): 380-5.

[84] Battaglia D, Bossi S, Cascone P, et al. Tomato belowgroundaboveground interactions: Trichoderma longibrachiatum affects the performance of Macrosiphum euphorbiae and its natural antagonists. Mol Plant Microbe Interact. 2013; 26(10): 1249-56. 
[85] Lorito M, Woo SL, Harman GE, Monte E. Translational research on Trichoderma: from 'omics to the field. Annu Rev Phytopathol 2010; 48: 395-417.

[86] Harman GE, Lorito M, Lynch JM. Uses of Trichoderma spp. to alleviate or remediate soil and water pollution. Adv Appl Microbiol 2004; 56: 313-30.

[87] d'Aquino L, Morgana M, Carboni MA, et al. Effect of some rare earth elements on the growth and lanthanide accumulation in different Trichoderma strains. Soil Biol Biochem 2009; 41(12): 2406-13.

[88] Divya LM, Prasanth GK, Sadasivan C. Potential of the salt-tolerant laccase-producing strain Trichoderma viride Pers. NFCCI-2745 from an estuary in the bioremediation of phenol-polluted environments. J Basic Microb 2013. [DOI: 10.1002/jobm.201200394]

[89] Lorito M, Woo SL, DAmbrosio M, et al. Synergistic interaction between cell wall degrading enzymes and membrane affecting compounds. Mol Plant Microbe In 1996; 9(3): 206-13.

[90] Woo S, Fogliano V, Scala F, Lorito M. Synergism between fungal enzymes and bacterial antibiotics may enhance biocontrol. Antonie Van Leeuwenhoek 2002; 81(1-4): 353-6.

[91] Schirmbock M, Lorito M, Wang YL, Hayes CK, Arisan-Atac I, Scala F, et al. Parallel formation and synergism of hydrolytic enzymes and peptaibol antibiotics, molecular mechanisms involved in the antagonistic action of Trichoderma harzianum against phytopathogenic fungi. Appl Environ Microbiol 1994; 60(12): 4364-70.

[92] Tripathi P, Singh P, Mishra A, et al. Trichoderma: a potential bioremediator for environmental clean up. Clean Techn Environ Policy 2013; 15(4): 541-50.

[93] Lan WJ Zhao Y, Xie ZL, et al. Novel sorbicillin analogues from the marine fungus Trichoderma sp. associated with the seastar Acanthaster planci. Nat Prod Commun 2012; 7(10): 1337-40.

[94] D'Antò Vincenzo VR, Amato M, Schweikl H, et al. Effect of nickel chloride on cell proliferation. Open Dent J 2012; 6: 177-81.
[95] Spagnuolo G, Desiderio C, Rivieccio V, et al. In vitro cellular detoxification of triethylene glycol dimethacrylate by adduct formation with N-acetylcysteine. Dent Mater 2013; 29(8): e153-60.

[96] Bettiol W. Morandi MAB, Pinto ZV, et al. Produtos comerciais à base de agentes de biocontrole de doenças de plantas. 1a edição eletrônica 2012. Available from: http: //ainfo.cnptia.embrapa.br/digital/bitstream/item/66628/1/Doc-88-1.pdf

[97] Kabaluk J, Todd AM. Svircev Mark, Goettel S, Woo SG. The use and regulation of microbial pesticides in representative jurisdictions worldwide. IOBC Global 2010: 99.

[98] Sriram S, Savitha MJ, Rohini HS, Jalali SK. The most widely used fungal antagonist for plant disease management in India, Trichoderma viride is Trichoderma asperellum as confirmed by oligonucleotide barcode and morphological characters. Curr Sci India 2013; 104(10): 1332-40

[99] Druzhinina IS, Kopchinskiy AG, Kubicek CP. The first 100 Trichoderma species characterized by molecular data. Mycoscience 2006; 47(2): 55-64.

[100] IOBC/WPRS. Classical and augmentative biological control against diseases and pests: critical status analysis and review of factors influencing their success: International Organization for Biological and Integrated Control of Noxious Animals and Plants, West Palaearctic Regional Section (IOBC/WPRS); 2011 August 2011].

[101] Friedl MA, Druzhinina IS. Taxon-specific metagenomics of Trichoderma reveals a narrow community of opportunistic species that regulate each other's development. Microbiology 2012; 158(1): 69-83.

[102] Marra R, Ambrosino P, Carbone V, et al. Study of the three-way interaction between Trichoderma atroviride, plant and fungal pathogens by using a proteomic approach. Curr Genet 2006; 50(5): 307-21.

[103] Schmoll M, Schuster A. biology and biotechnology of Trichoderma. Appl Microbiol Biot 2010; 87(3): 787-99.

(C) Woo et al.; Licensee Bentham Open

This is an open access article licensed under the terms of the Creative Commons Attribution Non-Commercial License (http://creativecommons.org/ licenses/by-nc/3.0/), which permits unrestricted, non-commercial use, distribution and reproduction in any medium, provided the work is properly cited. 